ص ص ص[Tr-1ra

$$
\begin{aligned}
& \text { مجتمع المعرفة وتأثيره في العمل المعرفي } \\
& \text { بحث ميداني في القطاع المصرفي الأردني }
\end{aligned}
$$

$$
\begin{aligned}
& \text { الدكتور بلال السكارنة } \\
& \text { مساعد عميدكلية العلوم الإدارية } \\
& \text { جامعة الإسراء الخاصة-الأردن } \\
& \text { أستاذ مساعد المانداب } \\
& \text { الكلية التقنية الإدارية- الموصل }
\end{aligned}
$$

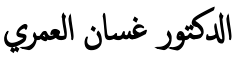$$
\text { عميد شؤون الطلبة }
$$

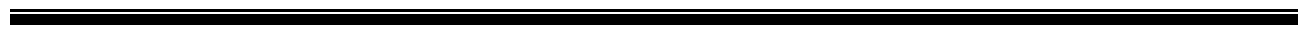

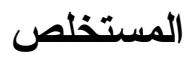

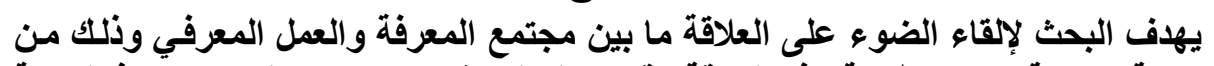

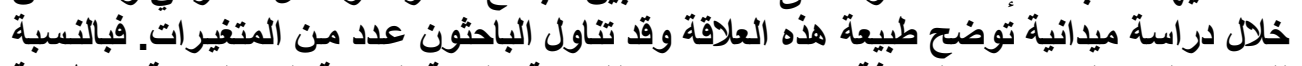

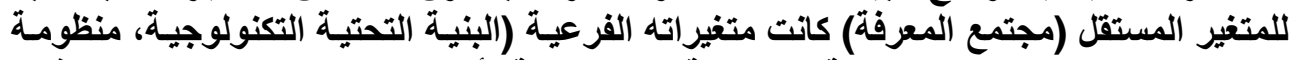

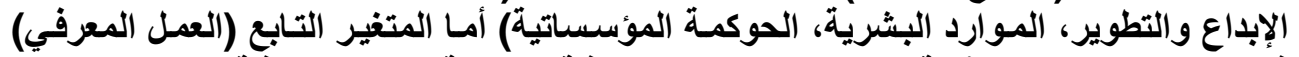

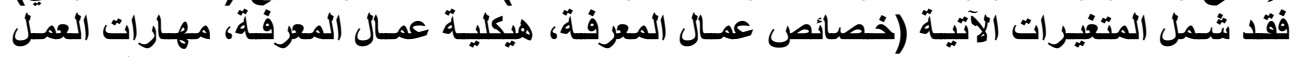

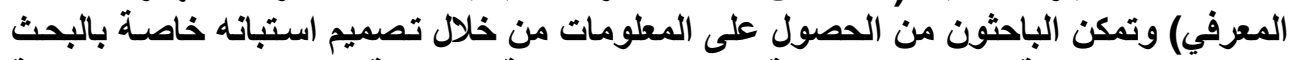

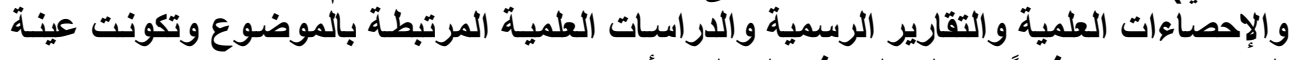

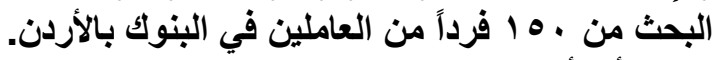

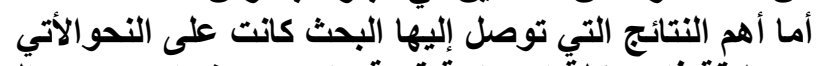

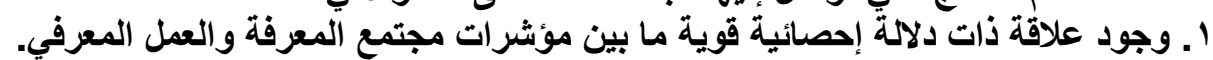

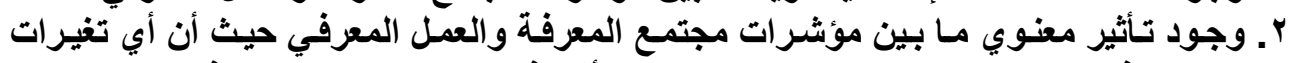

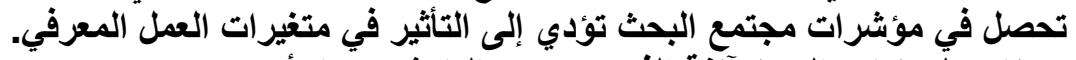

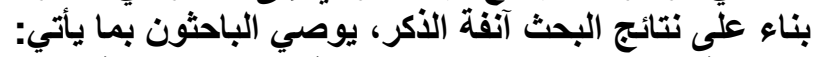

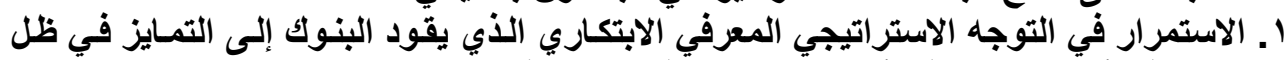

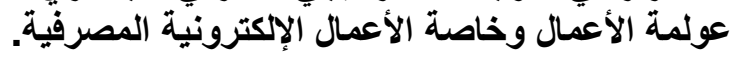

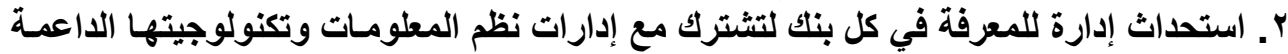

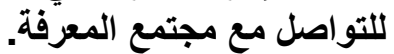

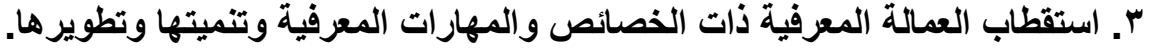
والمحافظة عليها لضمان ديمومـة رأس المـال البشري أهم مكونـات رأس المـال المعرفي والفكري في البنك.

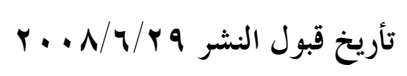




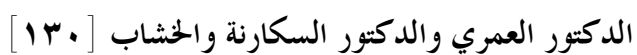

\title{
Knowledge Society and the Effect of Knowledge Work A Field Study of Jordanian Banking Sector
}

\author{
Ghassan Al-Omari (PhD) \\ Dean of Students Affairs \\ Private Israa University- \\ Jordan
}

Bilal Al-Sakarna (PhD)

Dean Assistant of College

of Administration Sciences

Private Israa University-

Jordan
Adeeb Y. Al-Khashab

Assistant Professor

Technical Administration

College

Mosul

\begin{abstract}
The current paper aims to spotlight on the relationship that holds between knowledge community and knowledge work. This was achieved through field study to explain the nature of this sort of relation. Different variables have been performed by the researchers. The sub variables of the single variable (knowledge community) were (infra structure technology, the system of creativity and development, human resources, and institutional governorance). The attached variable (knowledge work) is however of the following: (the characteristics of knowledge workers, the structure of knowledge workers, the skills of knowledge works). The data have been achieved by researchers through questionnaire, statistical analysis, official reports, and studies of the subject matter. The sample consisted of 150 individual of workers at Jordan banks. The most important results have been achieved as follows:

1. A fixed reference index has been presented between the indexes of knowledge community and knowledge work.

2. There is a significant effect between the knowledge community and knowledge work. So, any the variations happened in the community indexes may lead to the effect in the knowledge work.

Recommendations are:

1. Achieving the constant strategic direction of knowledge creativity that lead the banks to advantage through globalization of business electronic banking.

2. Presenting knowledge management in every bank for co operation with IT to keep coming with knowledge community.

3. Attracting the skillful knowledge workers and sustain the human capital as the most important part of it.
\end{abstract}

نتيجة للتطور ات السريعة و المتغيرة الحاصلة و لاسيما فـــي مجـــالات إنتـــاج

المعرفة وتقنياتها ووسائل الاتصال الحديثة، فقد شهدت العقود الثلاثة الأخيرة توجها

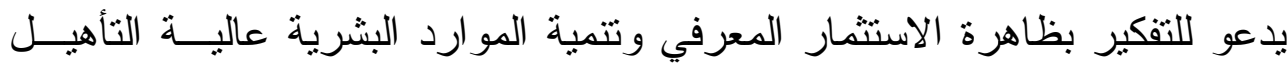

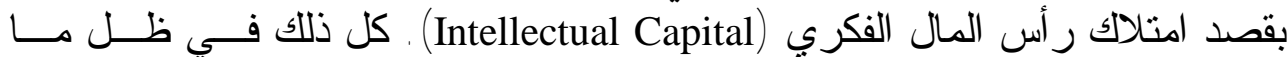
يعرف بمجتمع المعرفة (Knowledge Society) الذي يتصف بامتلاك أفر اده حرية الحصول على المعلومات و المعرفة وسهولة تداولها ونشر ها و التعامل معها، فضلاك

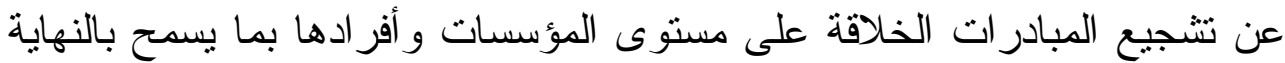
بأعلى توظيف ممكن للمعلومة و المعرفة المتداولة، وجعلها فـــي خدمـــة الإنـسـان 
لتحسين مستوى حياته نو عأ ونمطاً في مختلف المجالات، وذللك من خلال نو ع جديد الإني

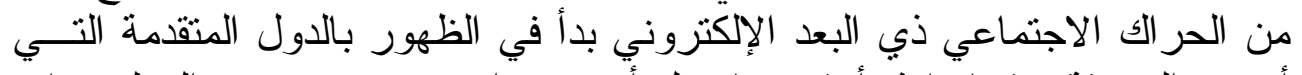

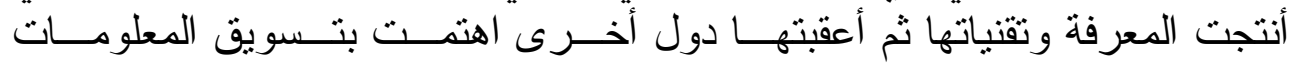

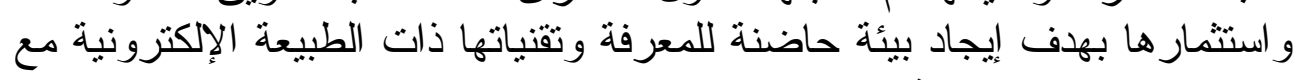

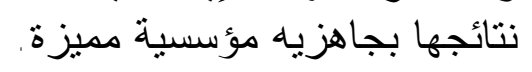

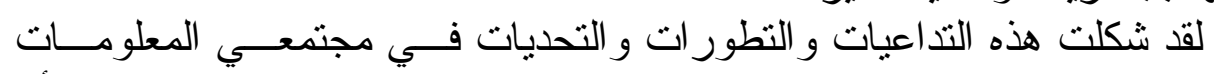

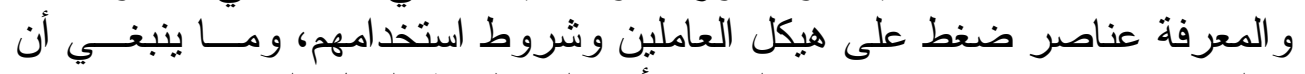

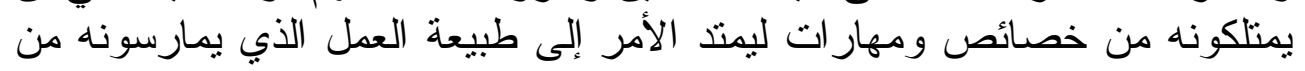

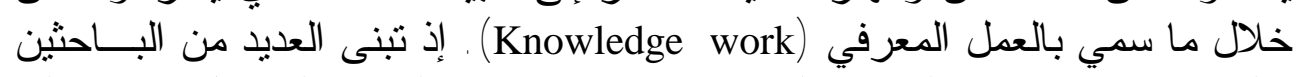

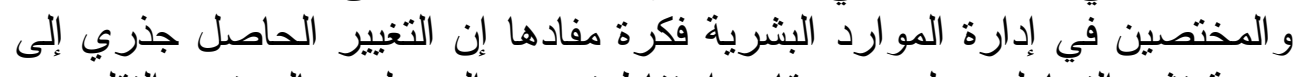

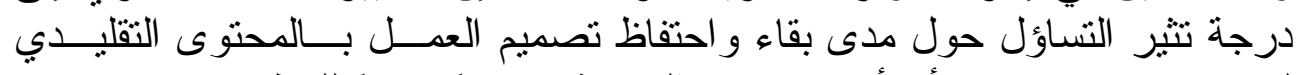

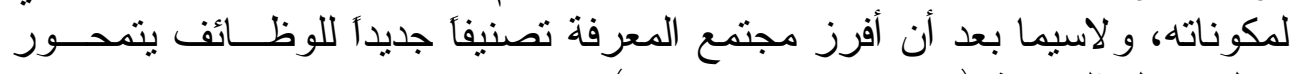
حول عمال المعرفة (Knowledge workers).

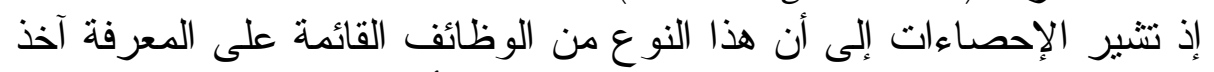

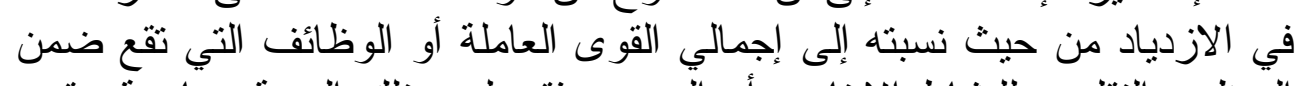

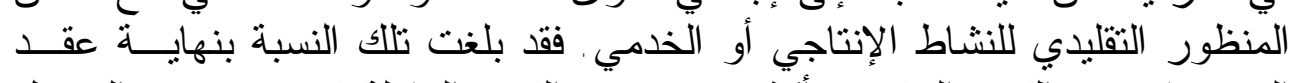

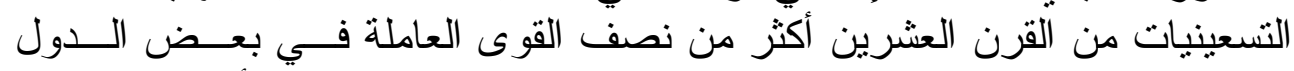

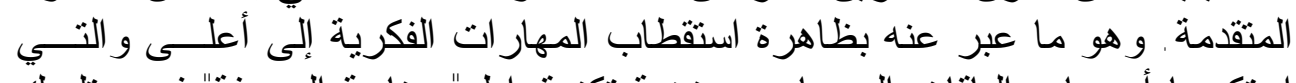

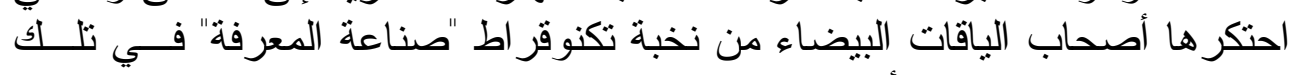

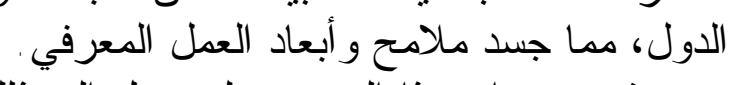

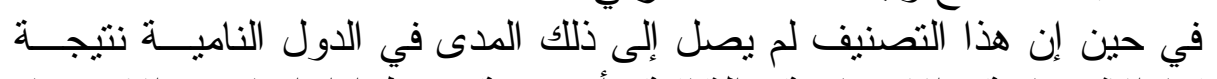

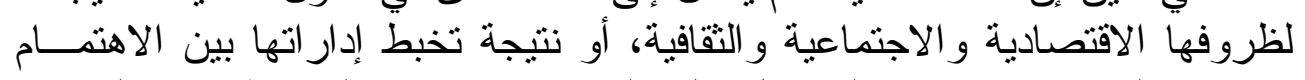

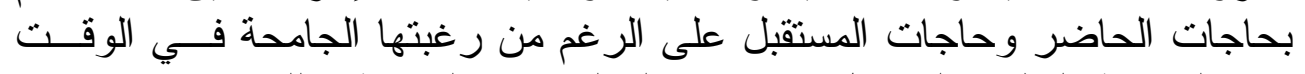

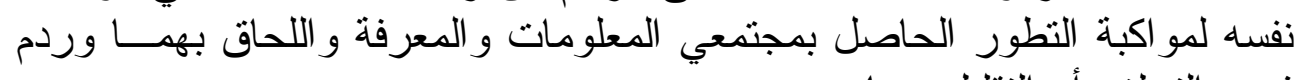
فجوة التخلف أو التقليل منها. وللتعامل مع هذه المشكلة وكثف أبعادها في المؤسسات الاقتصادية الأردنية،

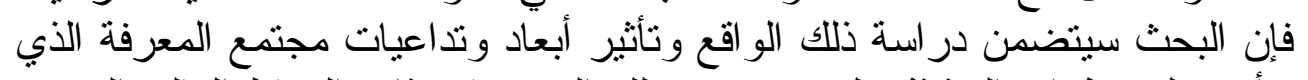

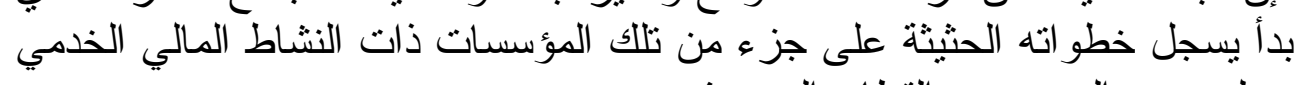

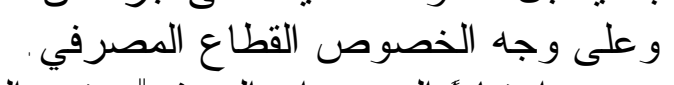

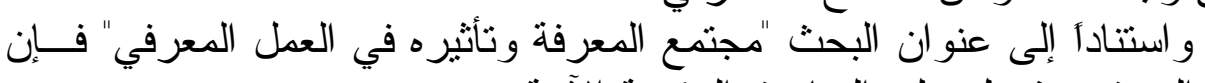
خطة البحث ستشتمل على المباحث الرئيسة الآتية:

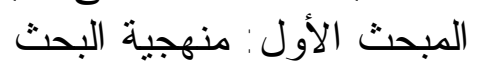
المبحث الثاني: الإطار النظري لإلهي للبحث:

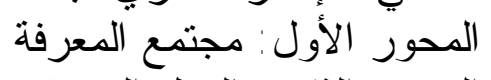
المحور الثاني: العمل المعرفي الدمرفي المبحث الثالث: الإطَّار الميداني للبحثي لإنى 


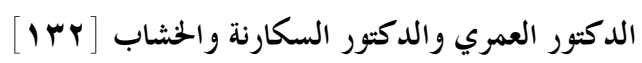

المبحث الر ابع :الاستتناجات و التوصيات

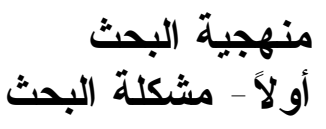

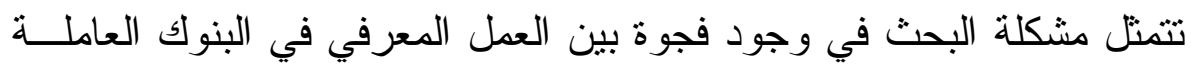

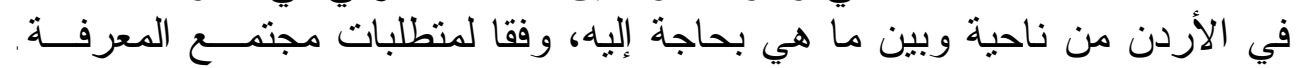

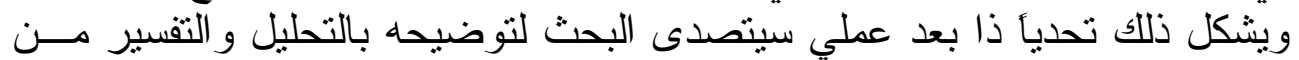

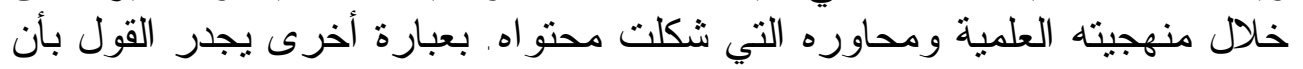

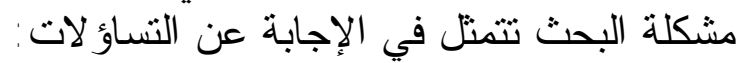

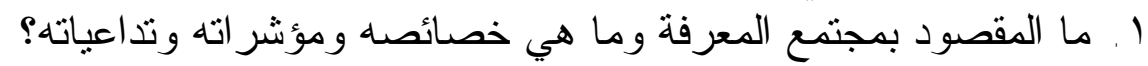

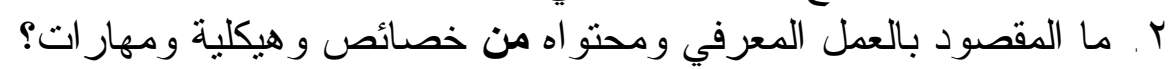

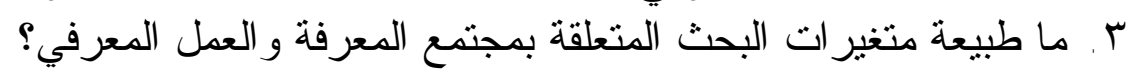

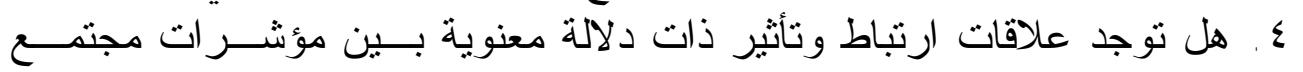

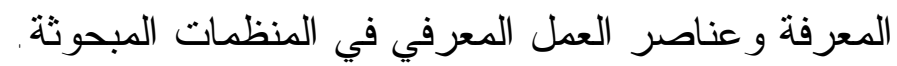

تتبع أهمية البحث ميدانياً من أهمية عينته ومتغير اته، وما لها من دور بــارز

ثناتياً - أهمية البحث

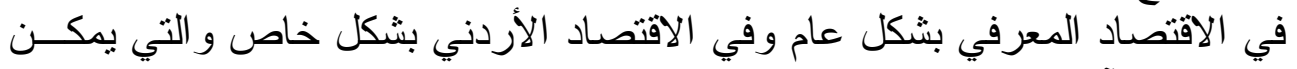

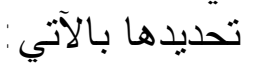
1 ـ بناء القدرات المعرفية الجوهرية هالية الية التقنية بوصفها أساس الميزة التتافـسية

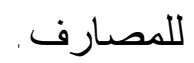
r . تعزيز بناء ر أس المال البشري كأحد مكونات ر أس المال المعرفــي و الفكــــي

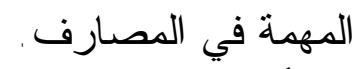

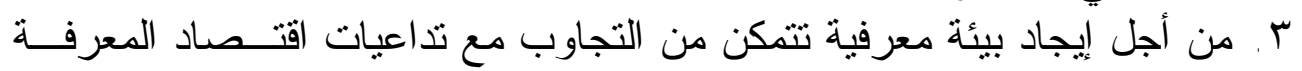

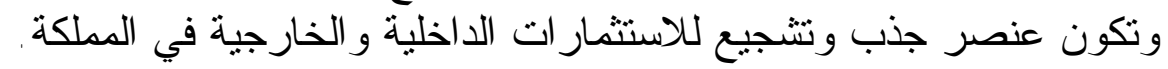

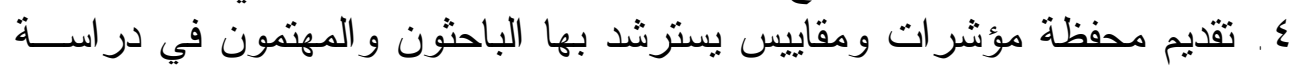

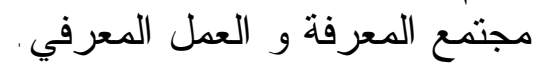

ثالثاً - أهداف البحث

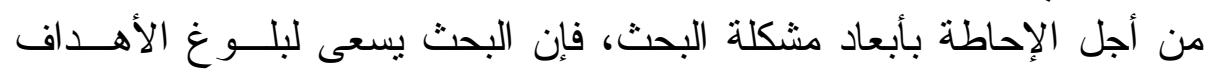
الآتية: 1 ـ تقديم بناء نظري لمفردات مجتمع المعرفة وطبيعة العمل المعرفي مــن حبـــ

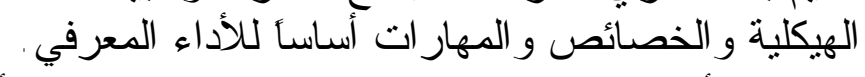

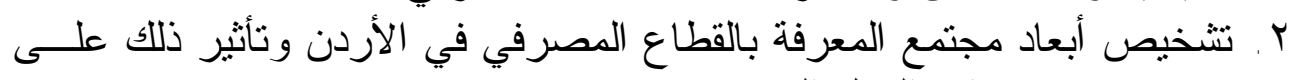

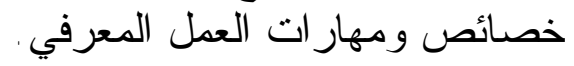


r. معالجة الفجوة المتعلقة بمشكلة البحث.

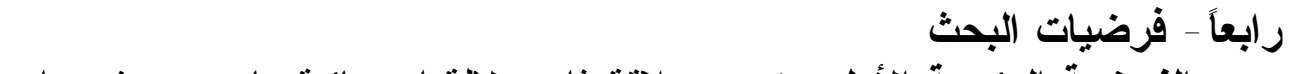

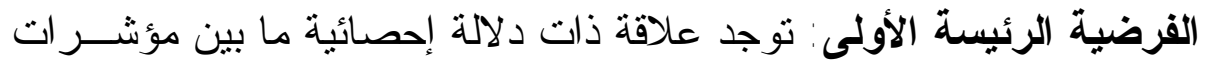

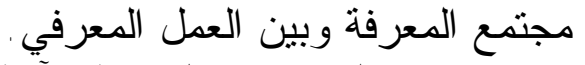
وتتبثق عنها الفرضيات الفربن العية الآتية:

1 ـ توجد علاقة ذات دلالة إحصائية ما بين البنية التحتية التكنولوجية وبين العــل

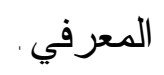

r . توجد علاقة ذات دلالة إحصائية ما بين الحوكمة المؤسـسـاتية وبــين العـــل

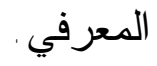

r. توجد علاقة ذات دلالة إحصائية ما بين المو ارد البشرية وبين العمل المعرفي.

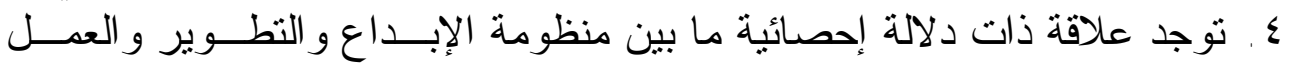

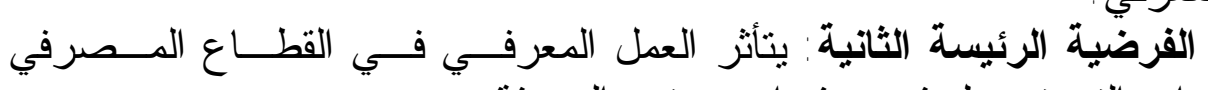

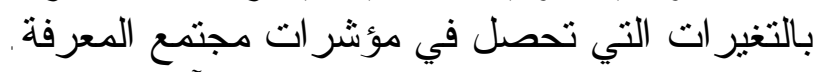
وتتبثق عنها الفرضيات الفر عية الآتية:

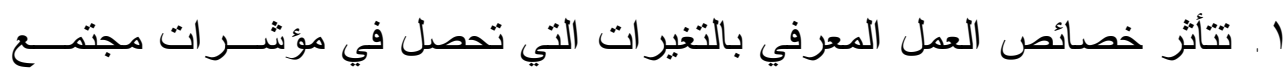

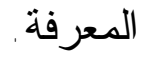
r . تتأثر هيكلية عمال المعرفة بالتغير ات التي تحــصل فــي مؤشــرات مجتـــع

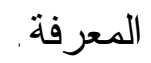
r. تتأثر مهار ات عمال المعرفة بالتغير ات التي تحصل فــي مؤشــرات مجتمــع

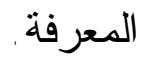


الدكتور العمري والدكتور السكارنة والمشاب [؛ ا]

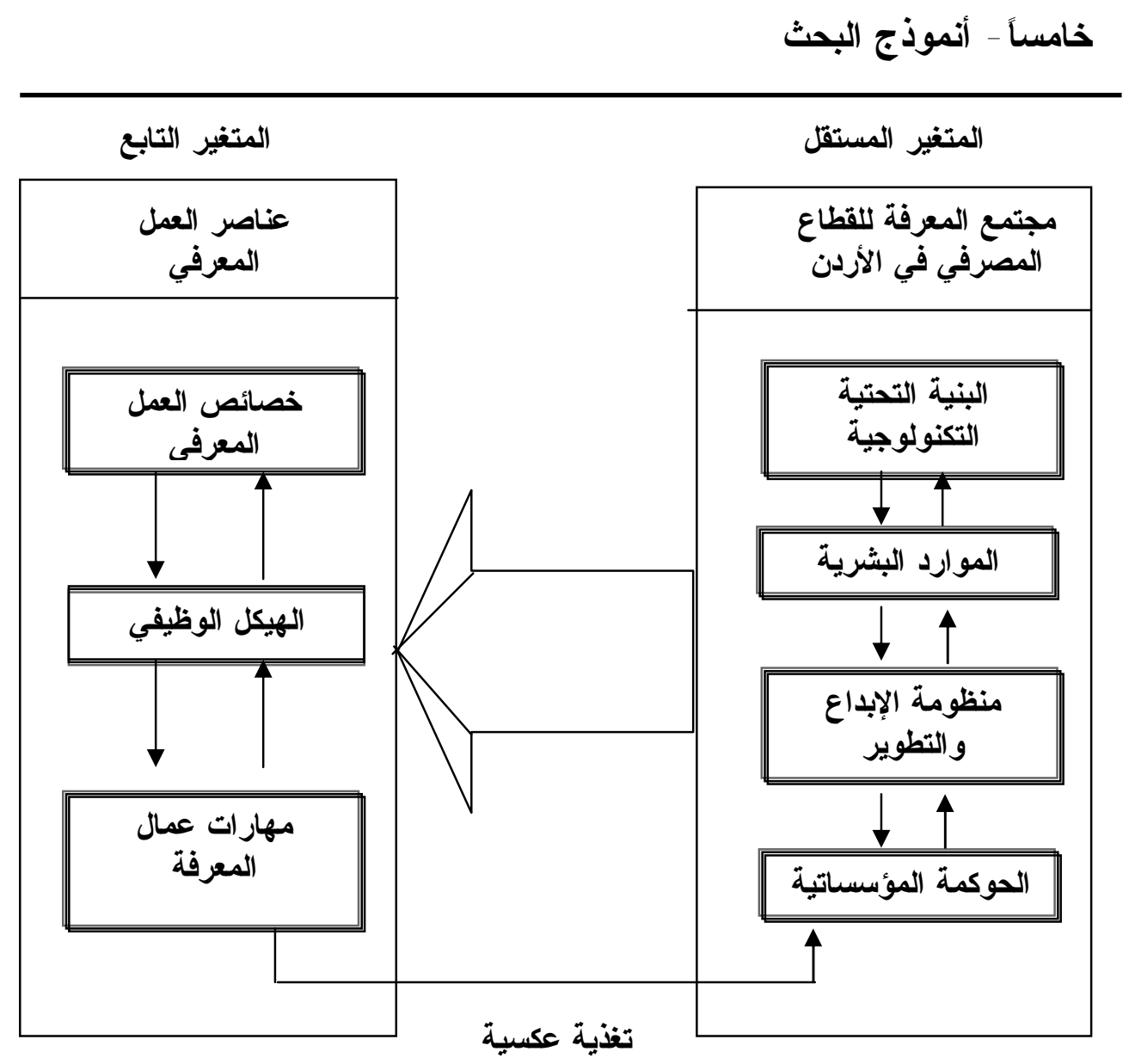

سادساً - أدوات البحث

لإخضاع مشكلة البحث للتحليل و الفحص، و لاختبار فرضياته، قام البـاحثون

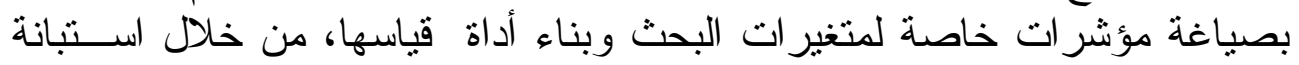

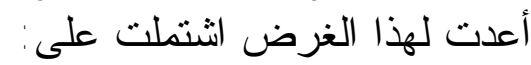
- أربعة مؤشر ات للمتغير المستقل (مجتمع المعرفة) تفر ع عنهــا تـسعة عـشر مقياساً.

- ستة مؤشرات للمتغير التابع (العمل المعرفي) تفرع عنها تشعة عـشر مقياســأ

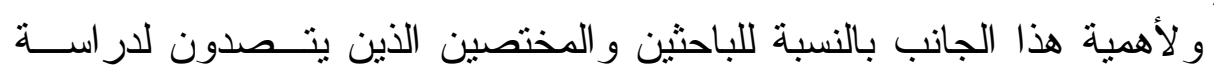

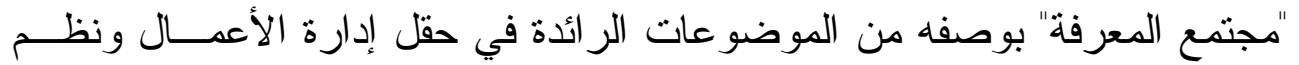

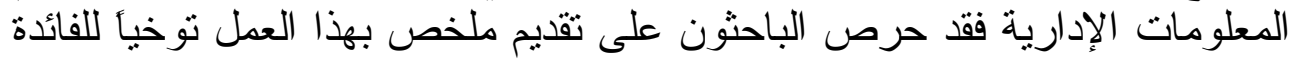
العلمية و العملية ذات الصلة بلّة بذلك. 
مؤشرات مجتمع المعرفة ويناء أداة قياسها

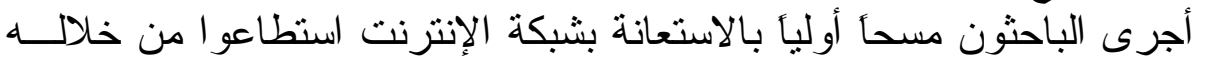

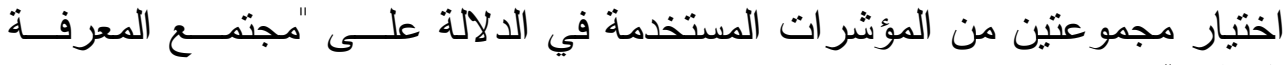

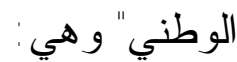

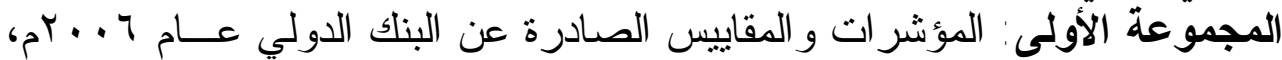

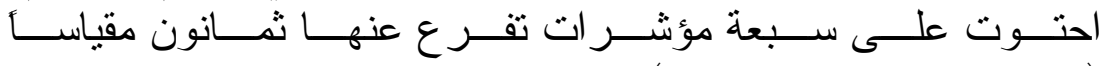

. (http://web.worldbank.org)

المجموعة الثانية: المؤشرات و المقاييس المقدمة للمؤتمر الإقليمي حول تكنولوجيا

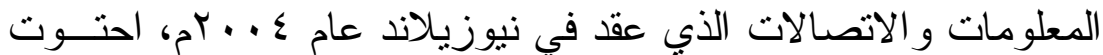

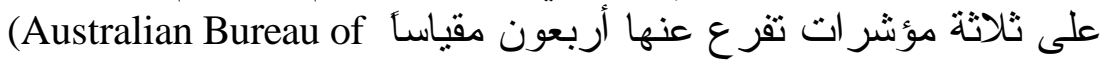
. Statistics, 2004)

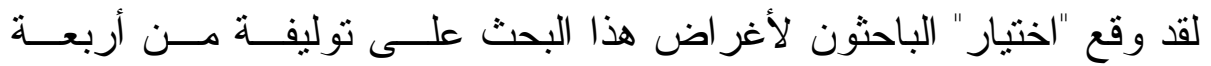

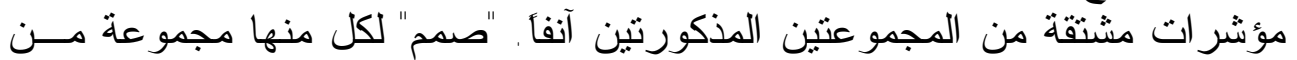

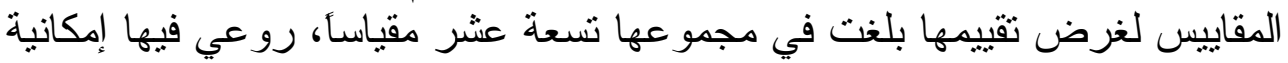

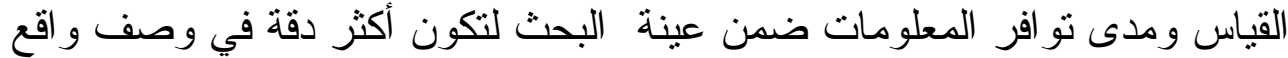

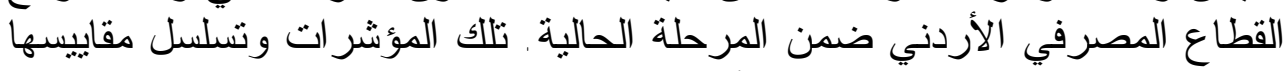

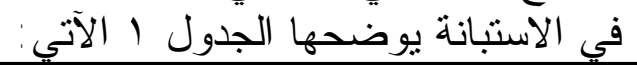

\section{الجدول المبيقل}

مؤشرات ومقاييس المتغير المستقل (مجتمع المعرفة)

\begin{tabular}{|c|c|}
\hline تسلسل الاستبانة & المؤشر ات والمقاييس \\
\hline $\begin{array}{l}(V) \\
(\wedge) \\
(9) \\
(1 .) \\
\end{array}$ & 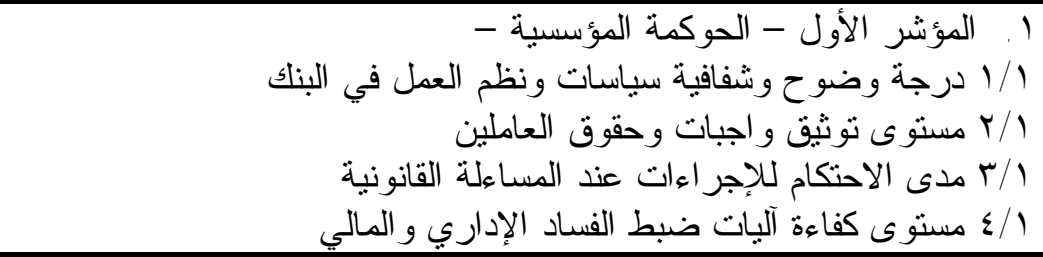 \\
\hline $\begin{array}{l}(11) \\
(19) \\
(10) \\
(111) \\
(19)\end{array}$ & 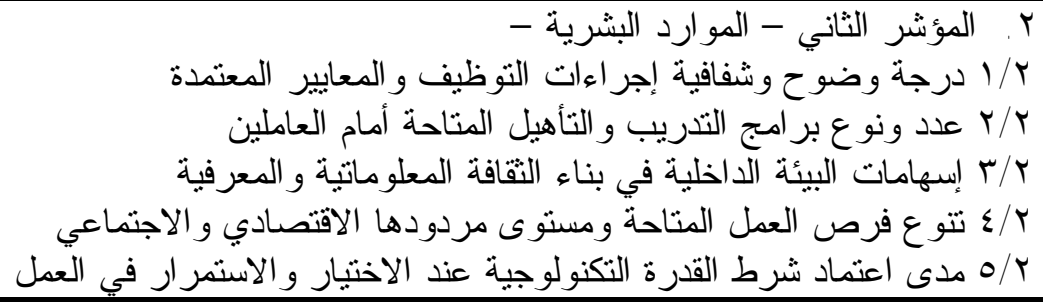 \\
\hline $\begin{array}{l}(1 T) \\
(1 \leq) \\
(10) \\
(1, Y)\end{array}$ & 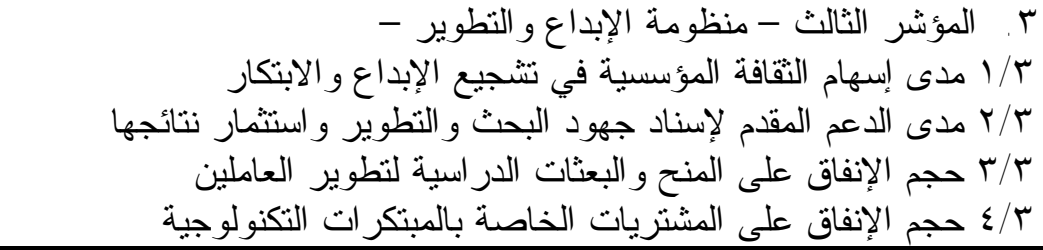 \\
\hline
\end{tabular}




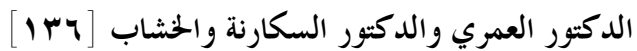

\begin{tabular}{|c|c|}
\hline تسلسل الاستبارة ت & المؤشر ات والمقاييس \\
\hline $\begin{array}{c}(r \cdot) \\
(r)) \\
(r r) \\
(r \leq / r r) \\
(r 0)\end{array}$ & 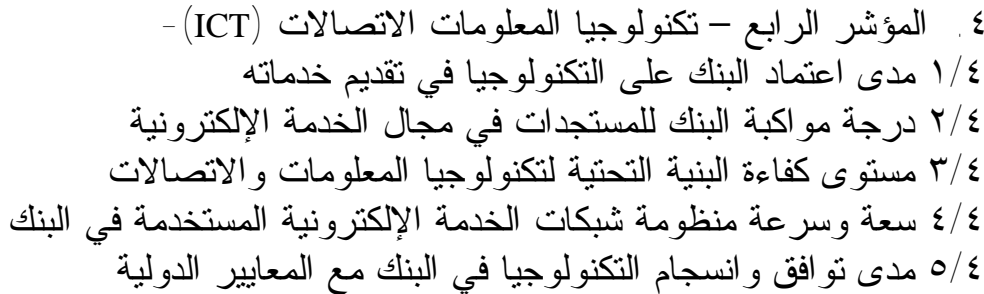 \\
\hline
\end{tabular}

\section{مؤشرات العمل المعرفي وبناء أداة قياسها}

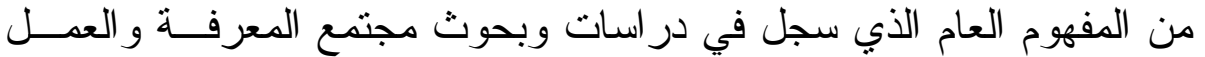

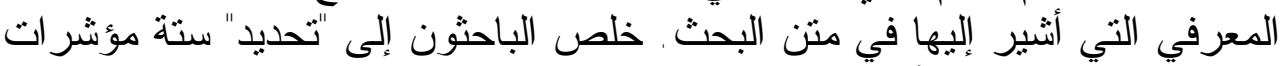

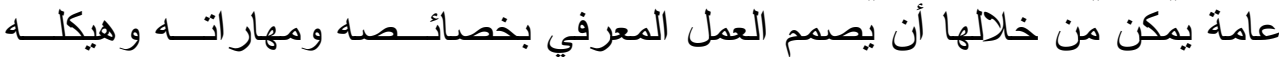

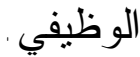

وللتمكن من استخدام تلك المؤشر ات و التحقق من وجودها ضمن عينة البحث،

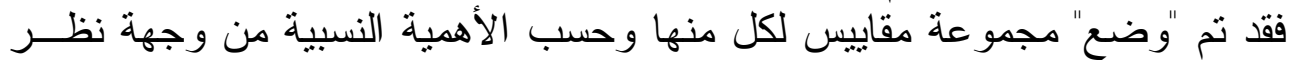

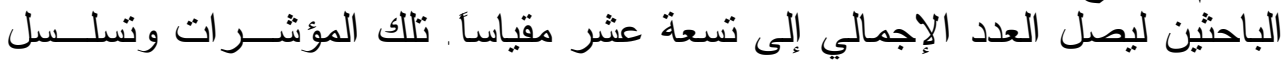

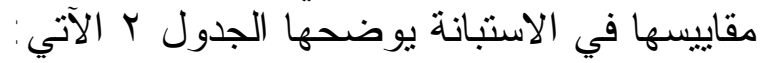

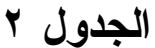

مؤشرات ومقاييس المتغير التابع (تصميم العمل المعرفي)

\begin{tabular}{|c|c|}
\hline تسلسل الَعبار ات في & المؤشر ات والمقاييس \\
\hline 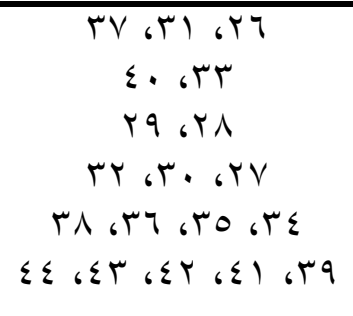 & 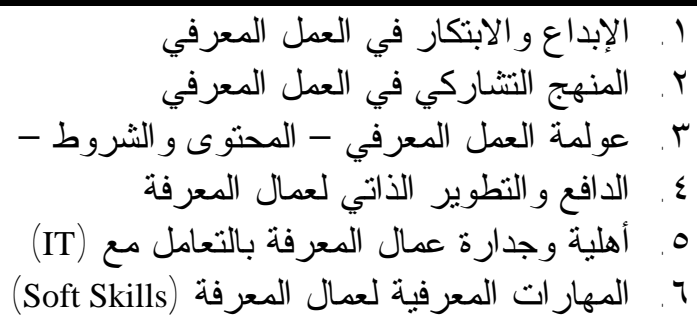 \\
\hline
\end{tabular}

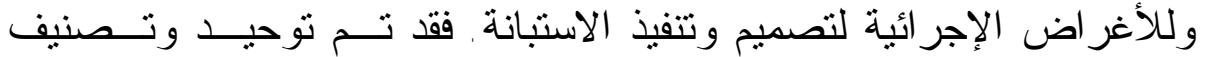

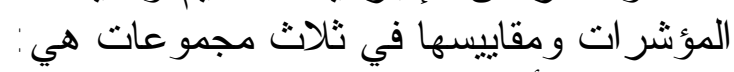

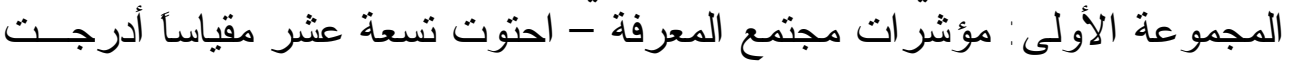
في الاستبانة تحت الفترة الفقرة ثنانياً. المجموعة الثانية: خصائص العمل المعرفي - احتوت أحد عثر مقياساً أدرجت في الاستبانة تحت الفقرة ثالثأ. 


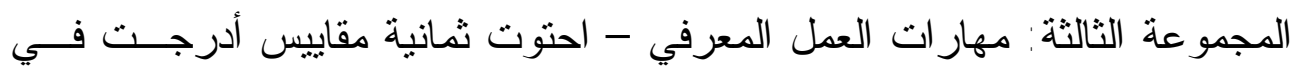

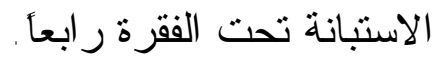

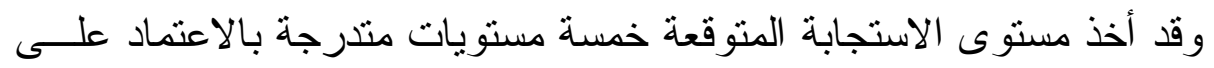

\begin{tabular}{|c|c|c|c|c|}
\hline 0 & $\varepsilon$ & $\Gamma$ & $r$ & 1 \\
\hline أتفق تماما & أتفق & نو عا ما & لا أتفق & لا أتفق تماماً \\
\hline
\end{tabular}

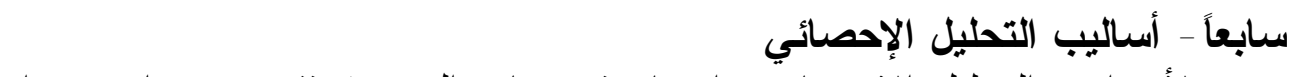

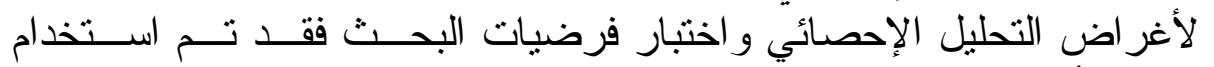

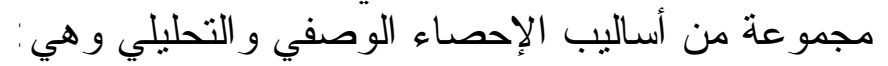

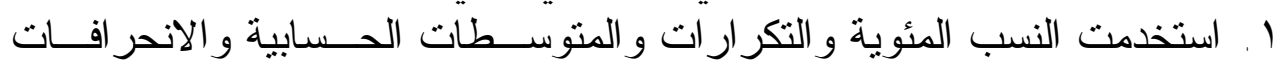

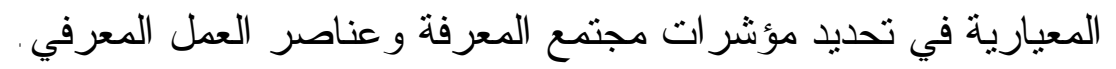

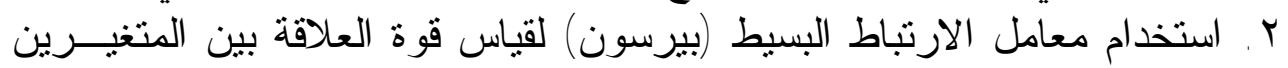

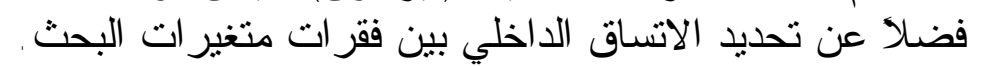

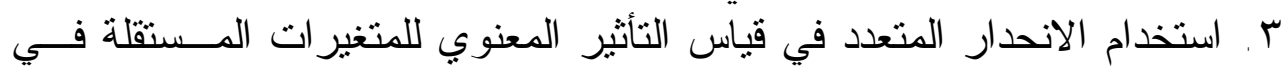

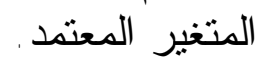

\section{ثامناً - صدق مقياس البحث وثباته}

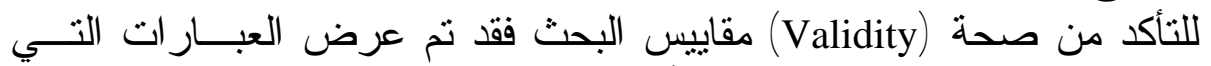

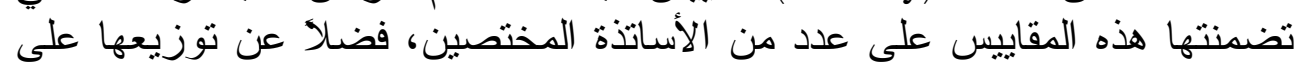

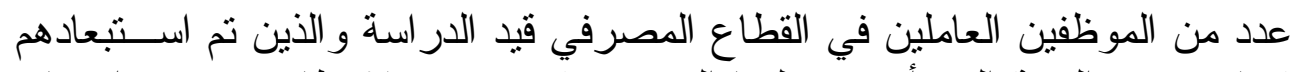

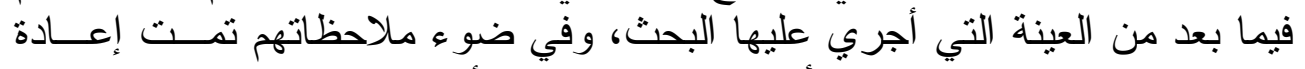

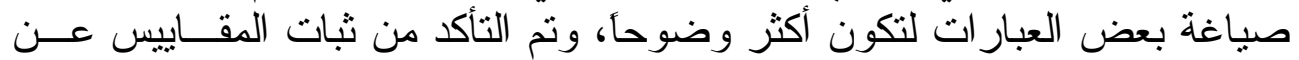

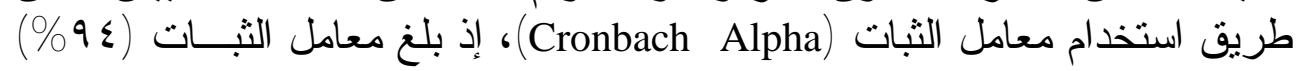
وهي نسبة مناسبة لإمكانية الاستمر ار في التحليل.

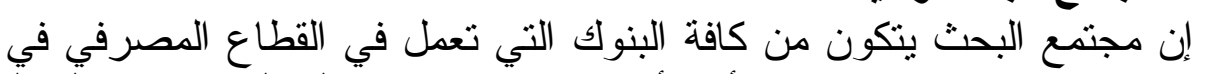

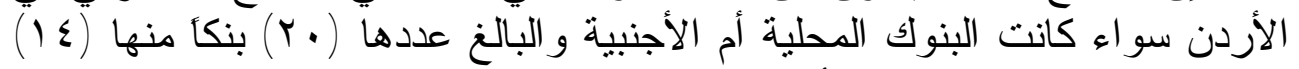

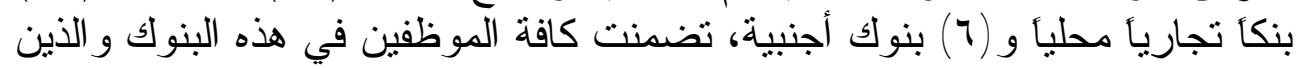

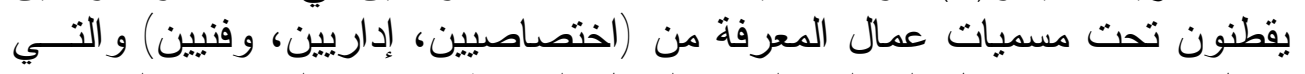

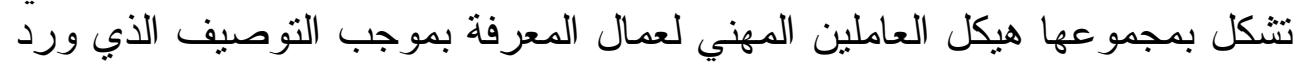

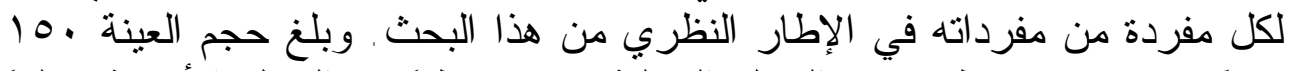

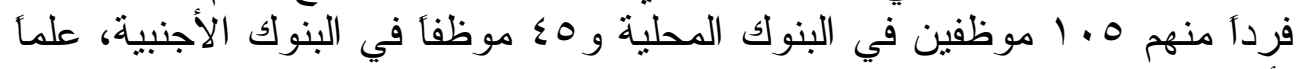

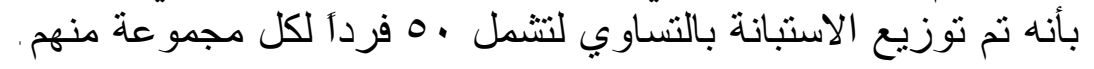




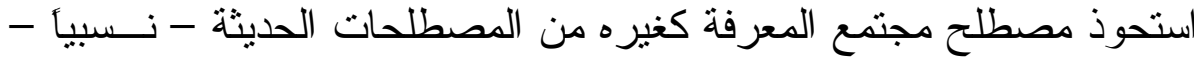
الإطار النظري للبحث

\section{مفهوم مجتمع المعرفة وخصائصه}

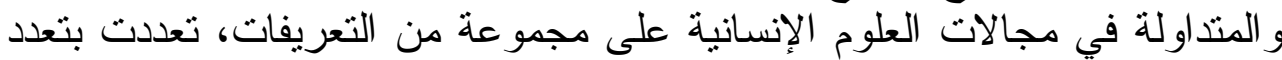

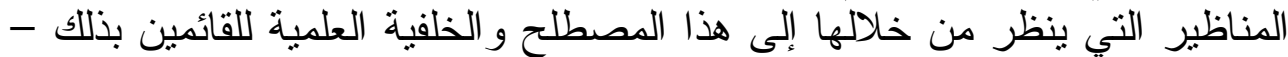

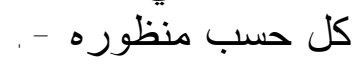

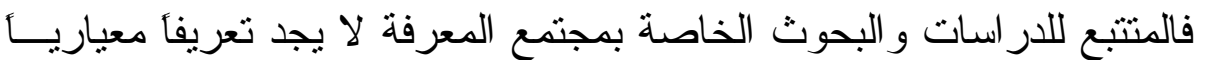

متعارفأ عليه، لكن هناك جملة من المفاهيم الثابتة للتعبير عنه ، كما ظهرت التهرت مسميات

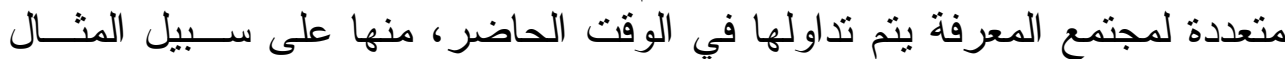

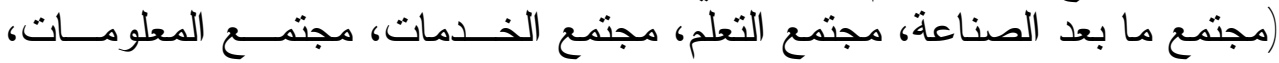

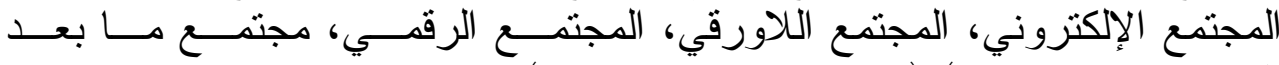

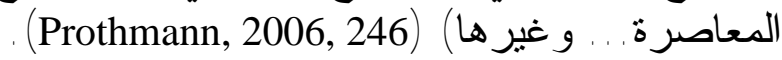

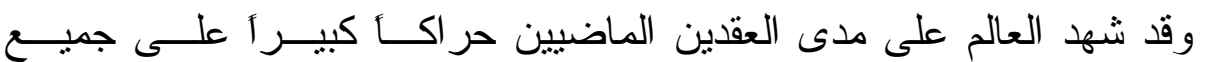

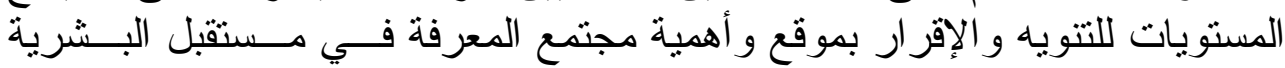

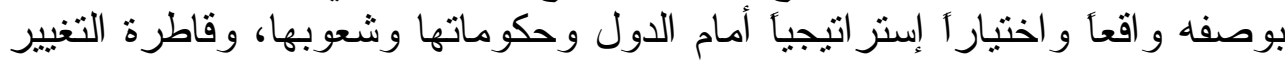
الاقتصادي و الاجتماعي و الثقافي و السياسي خلامل الته القرن الحادي و العشرين .

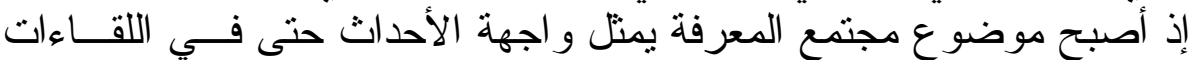

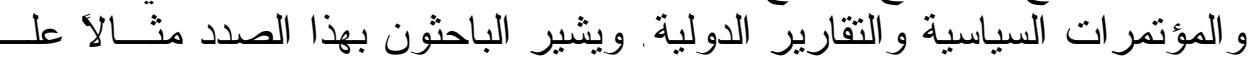

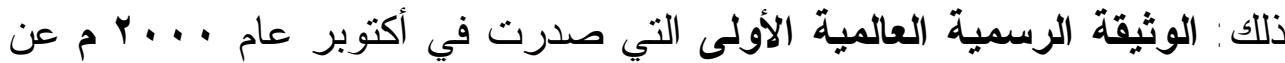

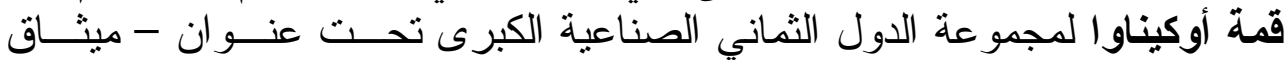

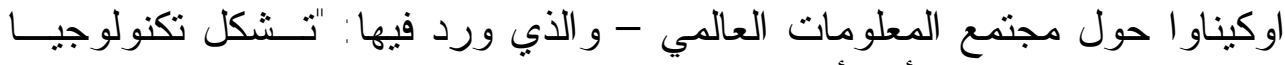

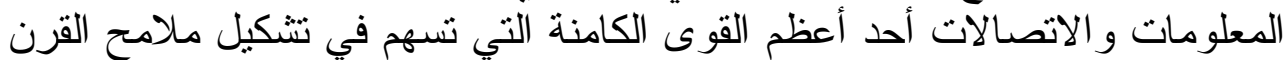

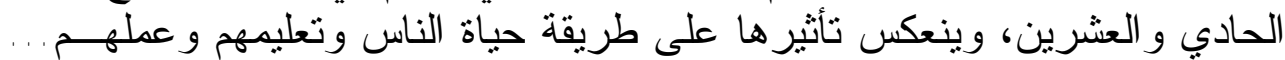

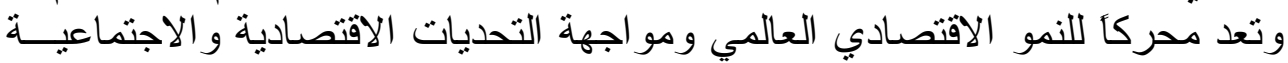

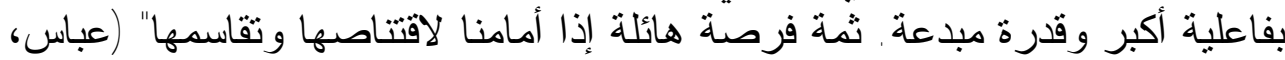

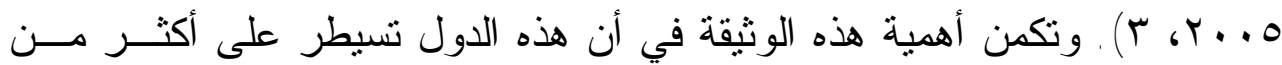

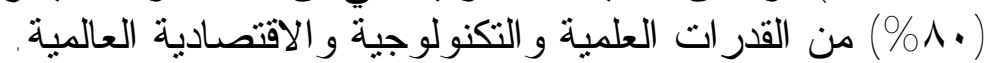

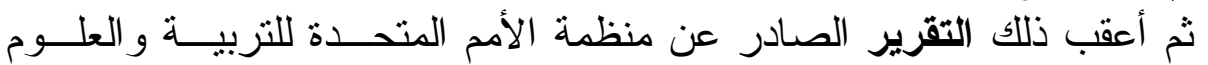

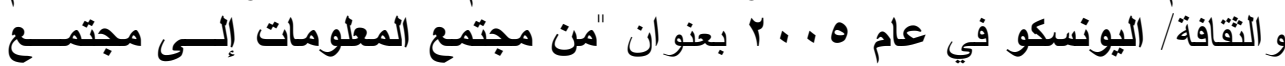

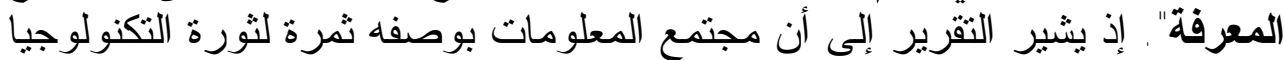

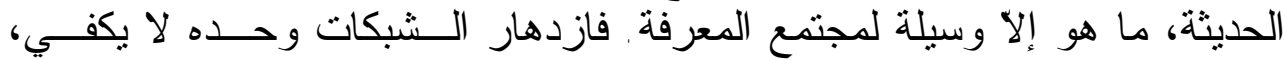

فالمعلومات وسيلة المعرفة وليست المعرفة بكاملها (http://portalunesco.org) .

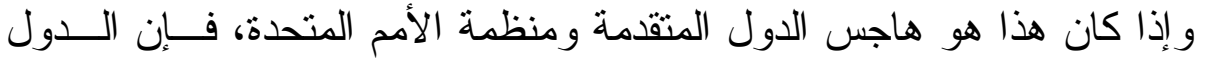

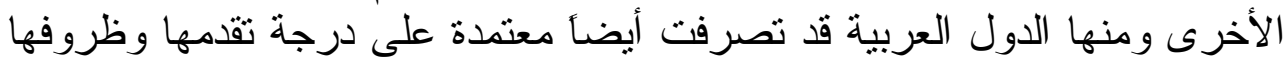

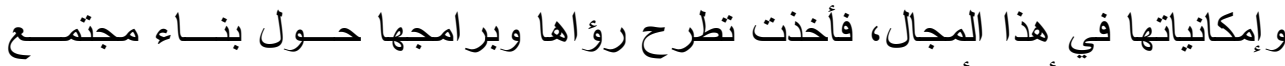

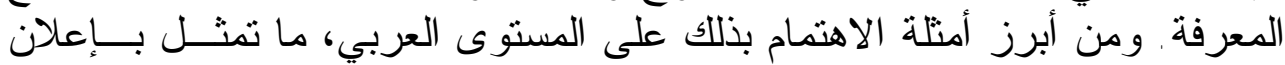




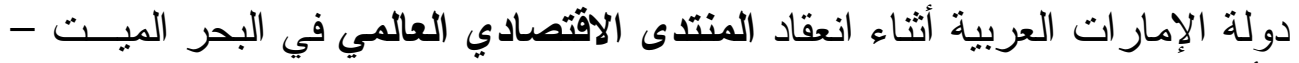

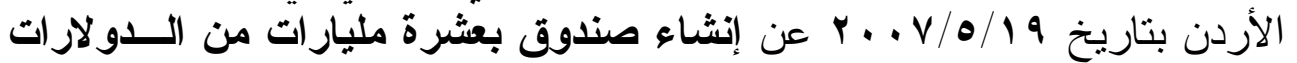

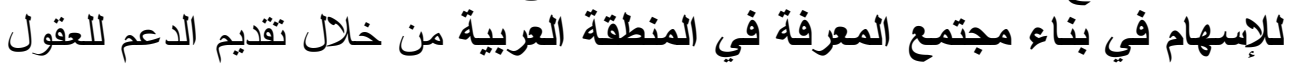

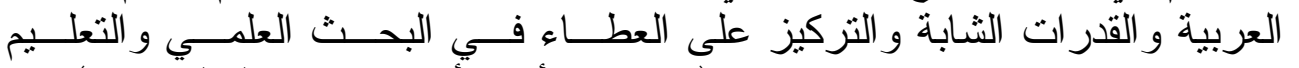

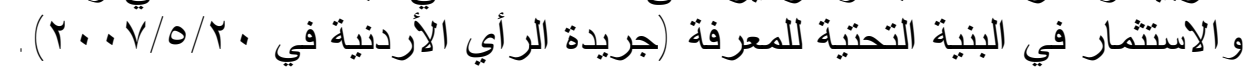

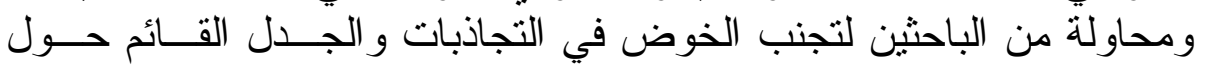

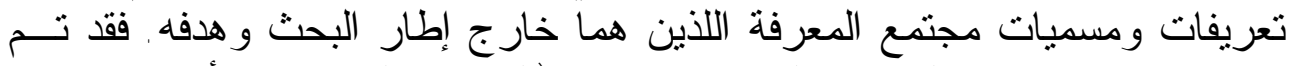

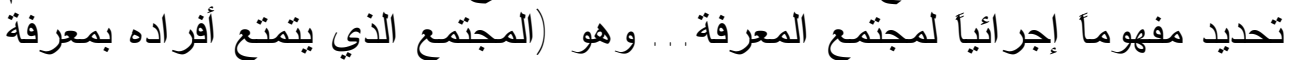

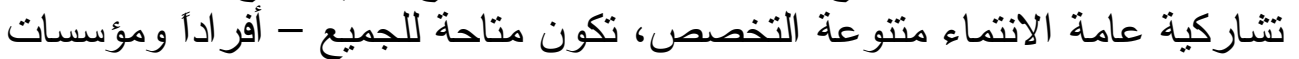

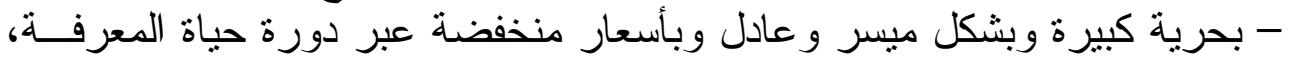

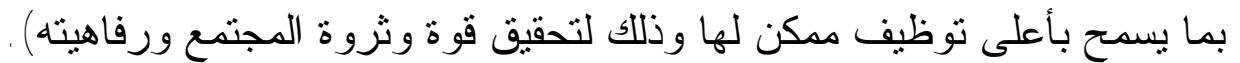

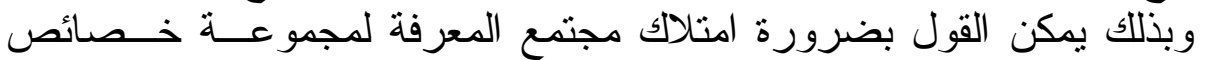

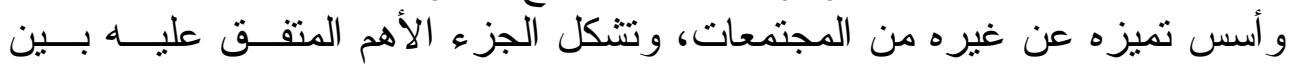

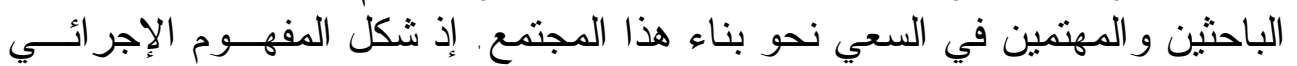

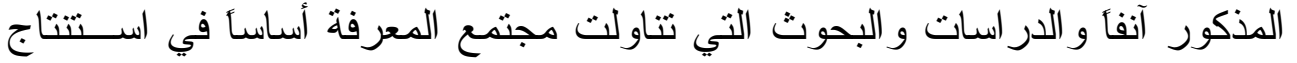

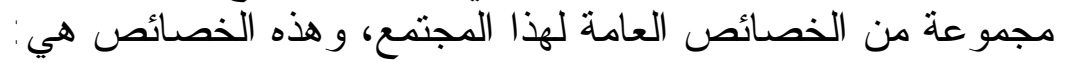

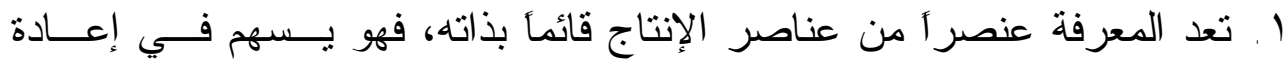

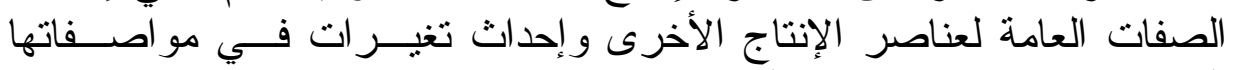

. (David and Foray, 2002,16) جعل ذللك المعرفة تمثل أحد أهم العناصر المسؤولة عن النمو الاقتصادي في وني

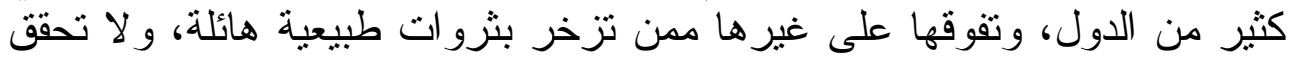
سوى معدلات نمو اقتصادية ضعنيفة.

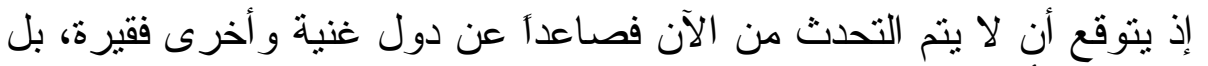

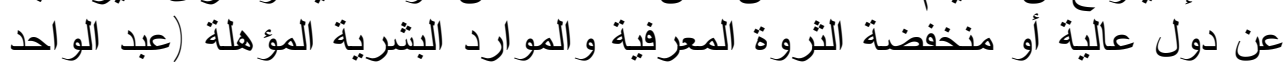

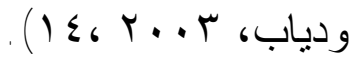

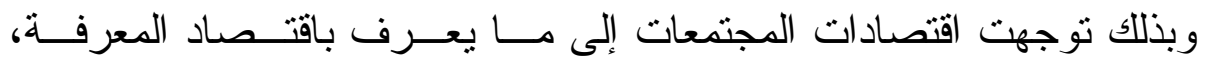

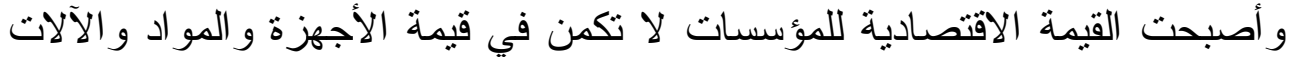

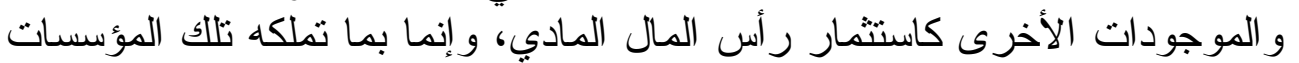

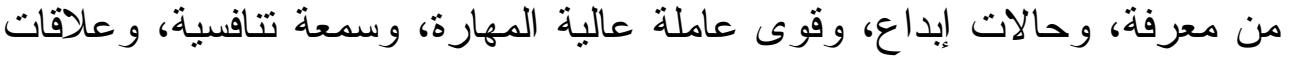

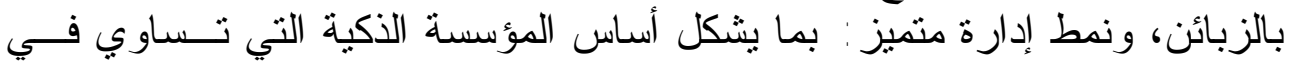
معادلتها = (تكنولوجيا + ر رأس المال الفكري + القيم) (Evers, 2001,5).

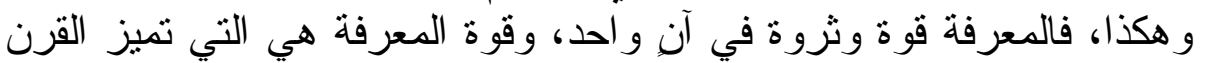

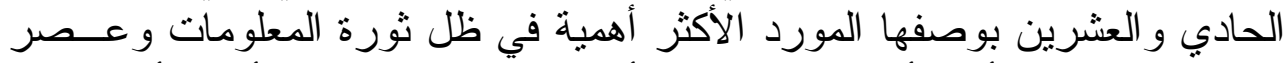

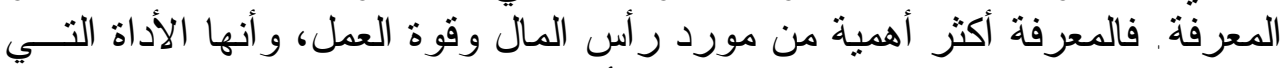

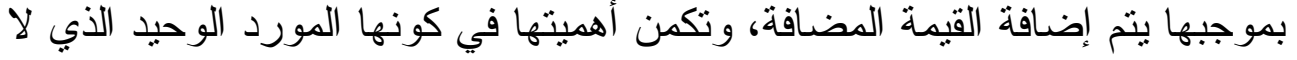

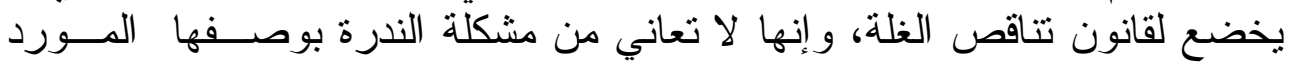


الدكتور العمري والدكتور السكارنة والحشاب [•ـ 1]

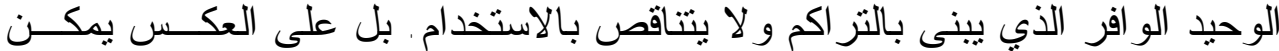

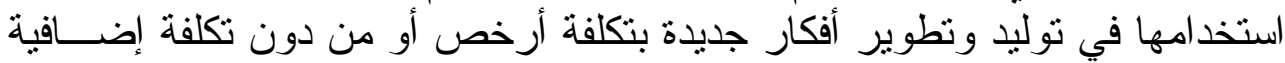

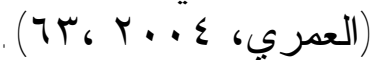
ومما تجدر الإثشارة إليه أن هناك ثلاثية أنواع من المعرفة الإستر اتيجية فـي

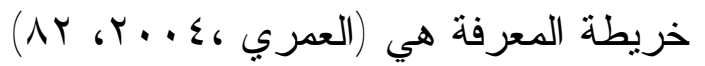

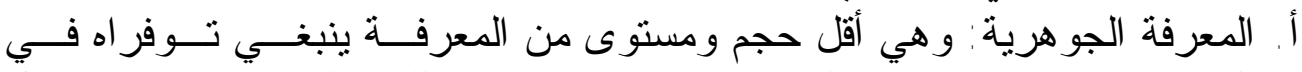

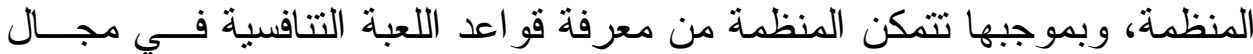

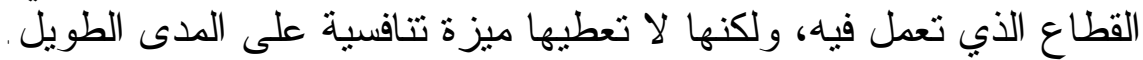

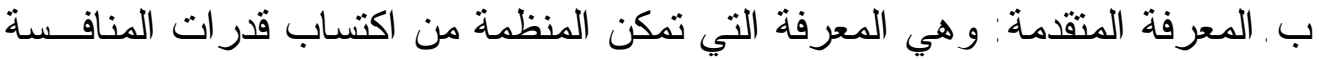

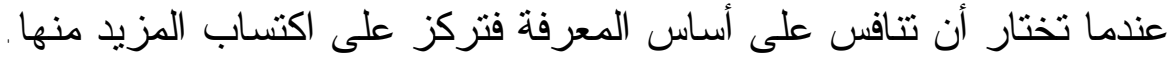

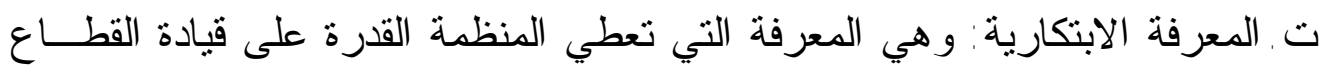

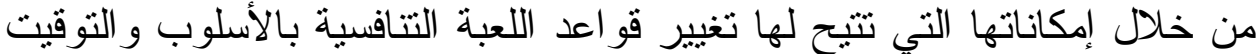

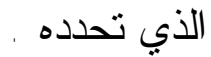

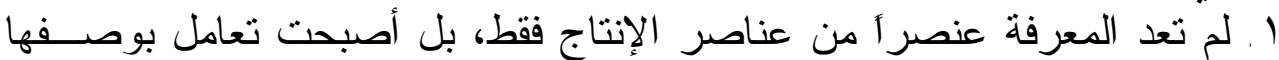

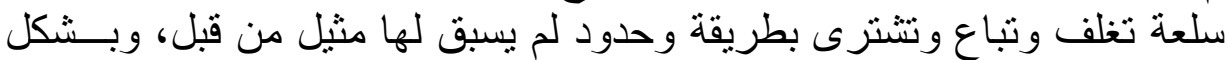

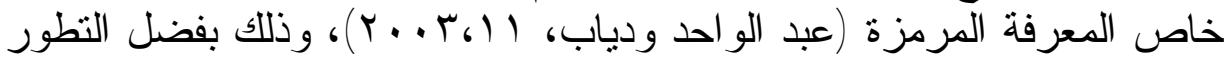
الهائل لتكنولوجيا المعلومات التي أسهمت في نسخ المعرفة وتدابل التها ولها بأسعار شبه

$$
\text { مجانية. }
$$

ولعل أهم ما يميز المعرفة بوصفها سلعة هو كونها تتز ايد وتتنامى مع تتامي لئي

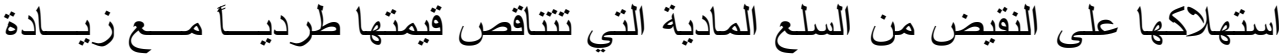

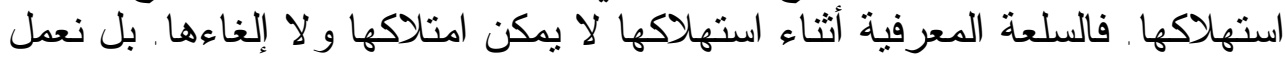

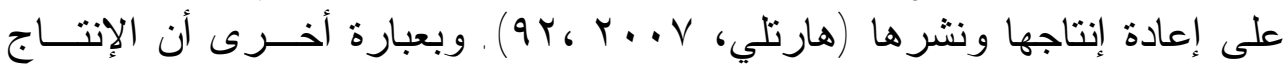

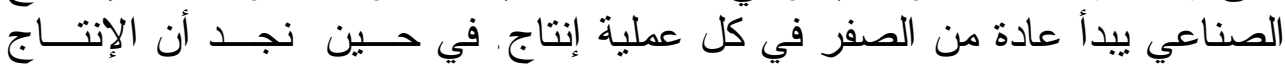

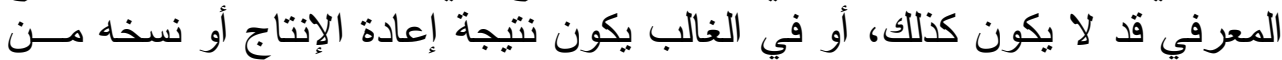

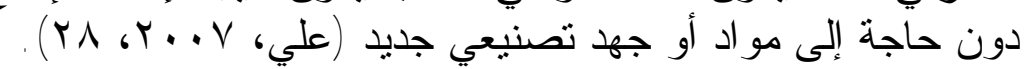

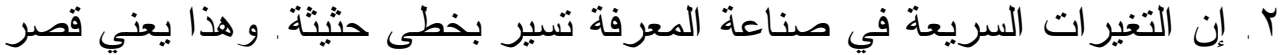

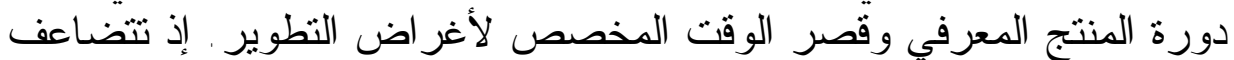

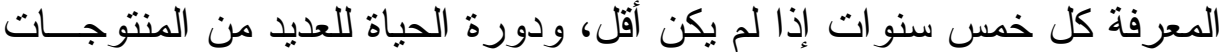

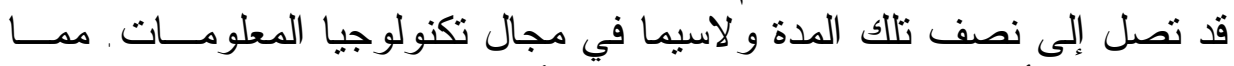

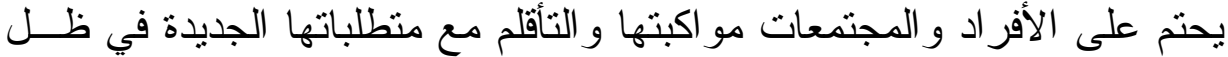
مجتمع المعرفة (Brinkley and Lee, 2006,73). ويندر أن تمر مدة زمنية من دون أن تحمل المجلات المتخصصة أنباء عـنـ فئن

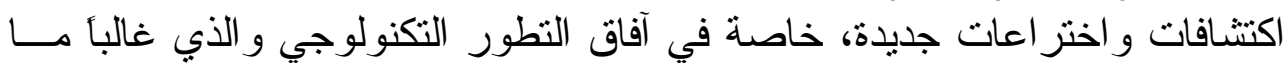

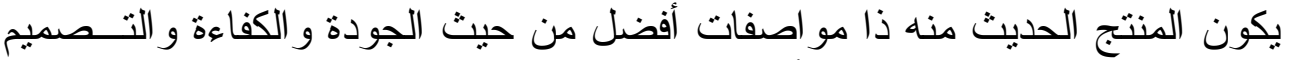

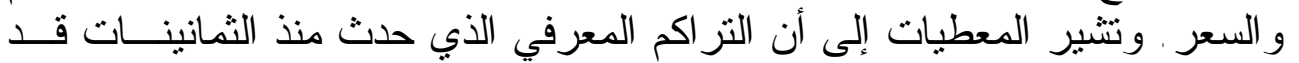


يو ازي ما ر اكمته البشرية من معارف طو ال آلاف السنين السابقة مسن تاريخهـــا

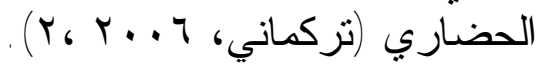

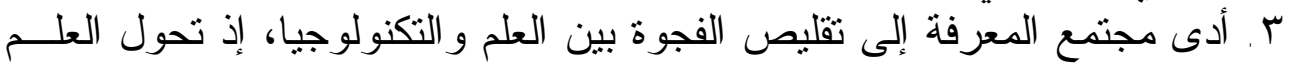

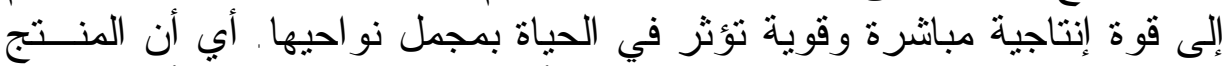

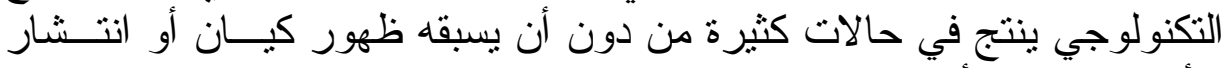

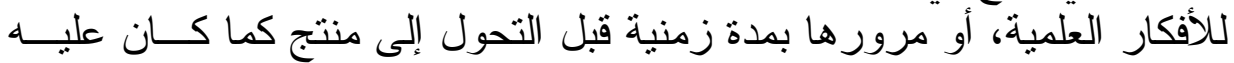

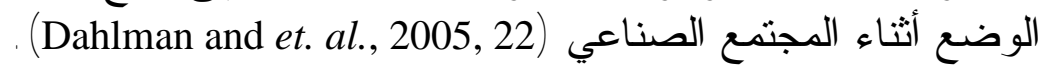

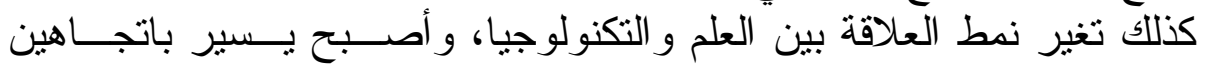

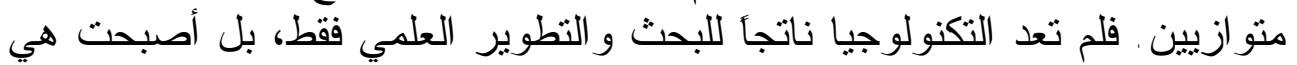

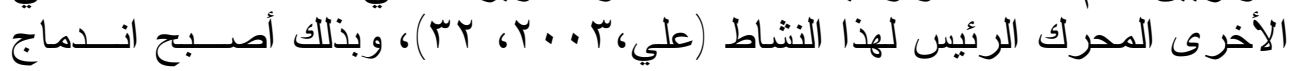

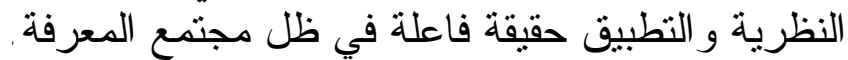

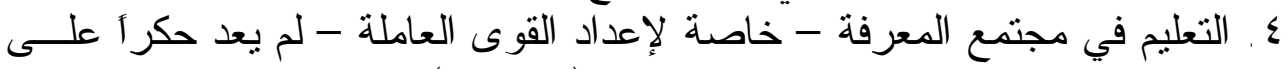

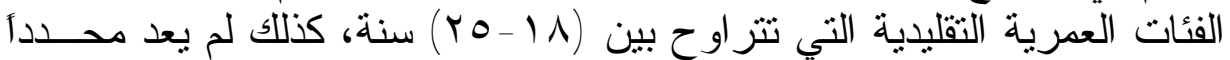

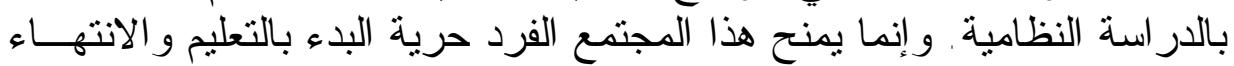

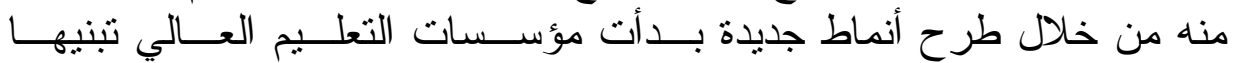

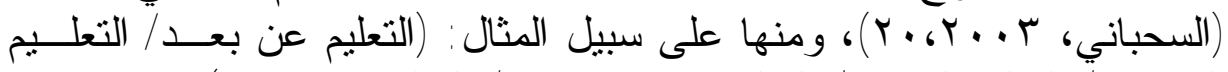

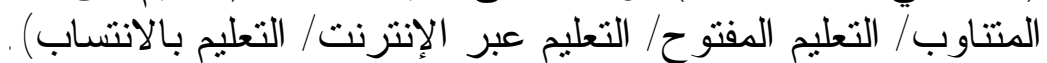

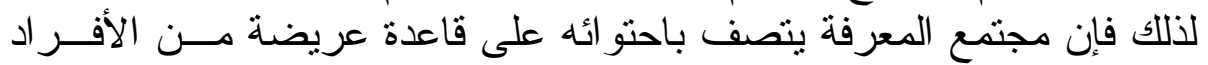

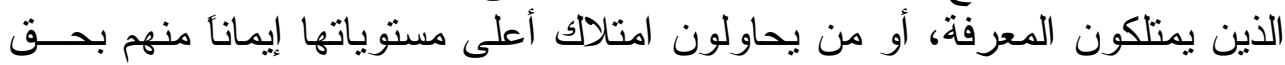

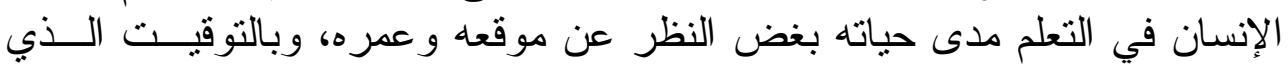

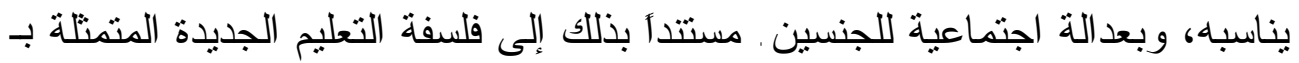
(التعليم من خلال العمل) إلى جانب الجنان (التعليم ثم العمل).

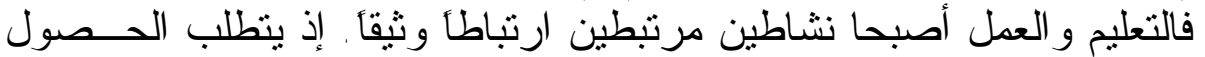

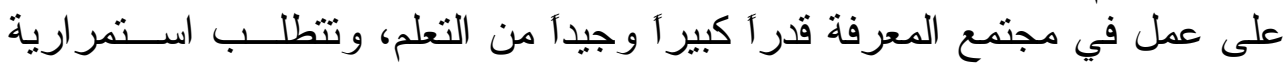

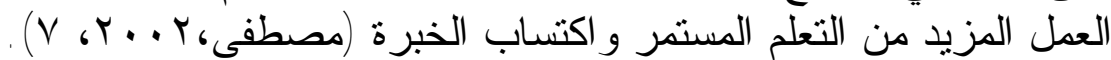

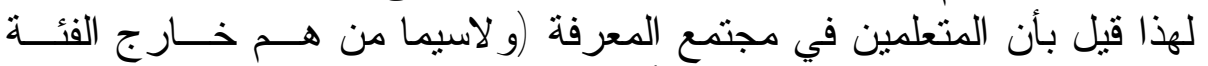

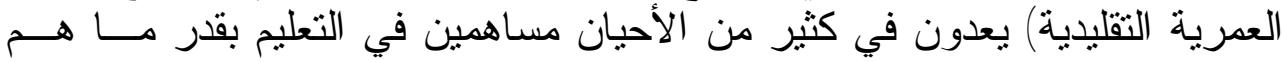
متلقين للمعرفة المغية.

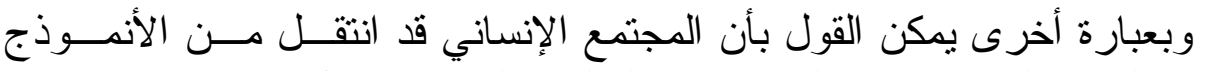

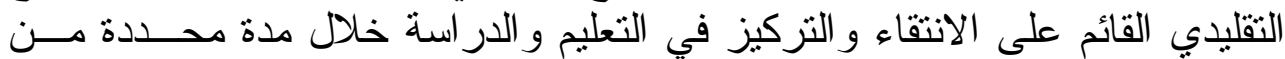

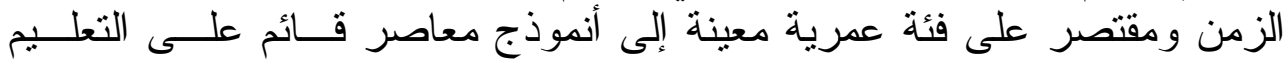

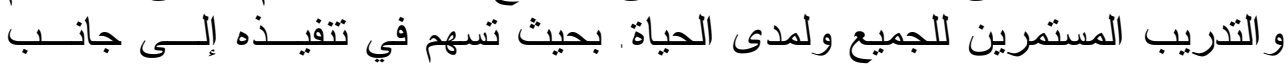

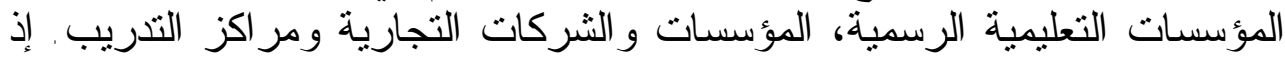

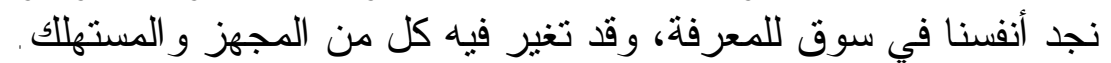

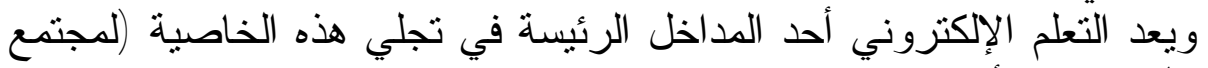

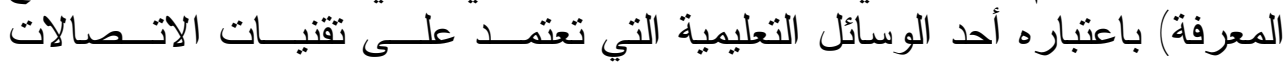


الدكتور العمري والدكتور السكارنة والحشاب [ب ع 1]

الإلكترونية وتقنيات الخدمة الذاتية لإتاحة المعرفة للذين يمارسون العمل وينتشرون

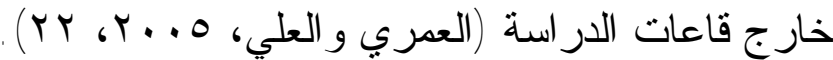

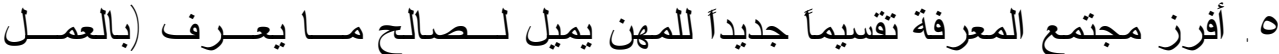

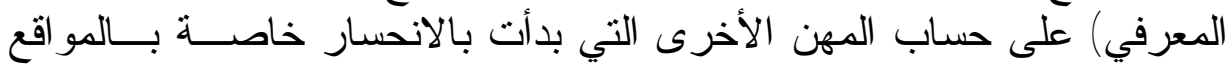

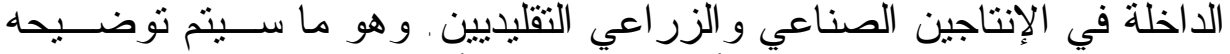

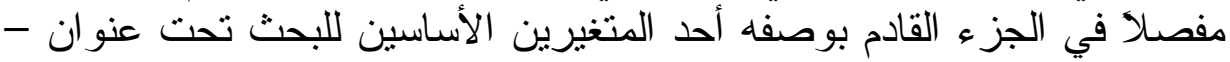

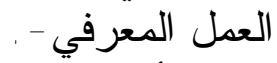

7 ـ ظهور أنماط جديدة من الإدارة عرفت بإدارة المعرفة (ر افعة الحكمة الجماعية)

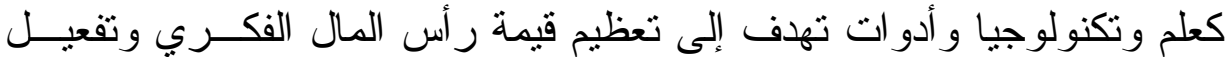

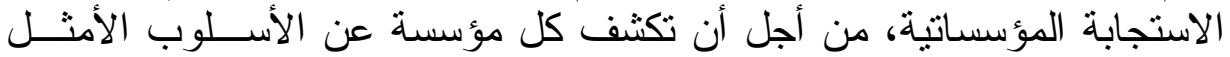

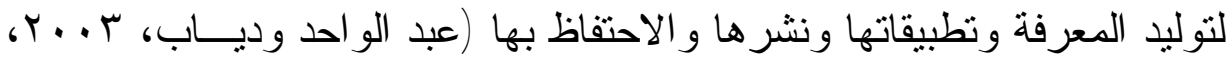
( t هذا وقد أوضح (Natarajan \& Skekhar, 2000, 31) أن ظهور إدارة المعرفة

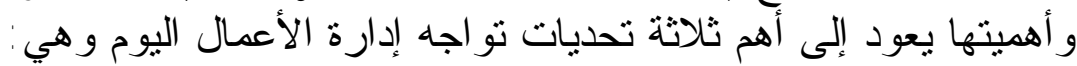

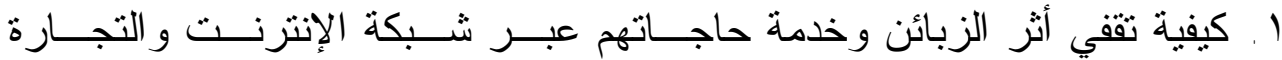
الإلكترونية. r. كيفية استخدام تكنولوجيا المعلومات في الحصول على حصة ومكانة في سوق

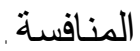
r. الآلية التي تمكّن الثركة من إعادة ترتيب أفكار العاملين وخبر اتهم المتر اكمـــة

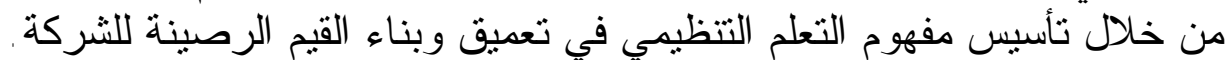

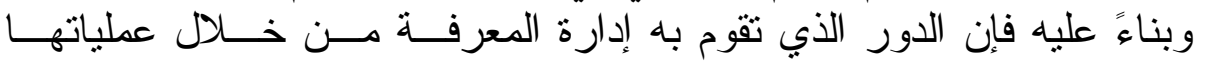

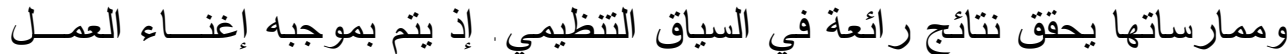

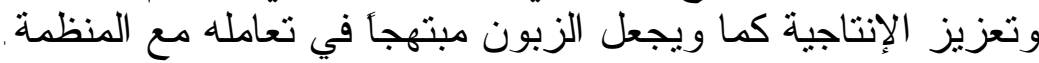

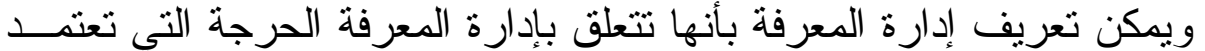

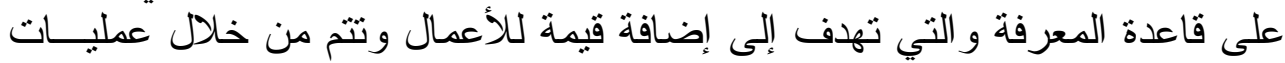

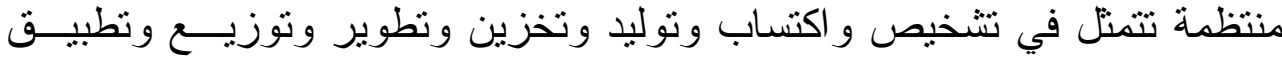

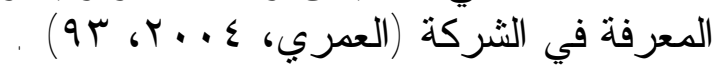

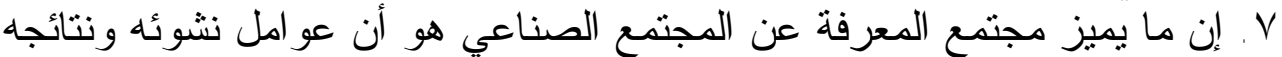

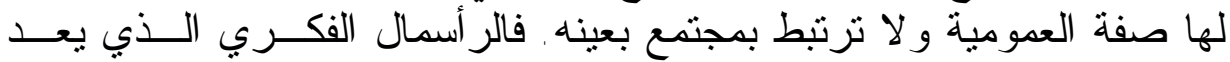

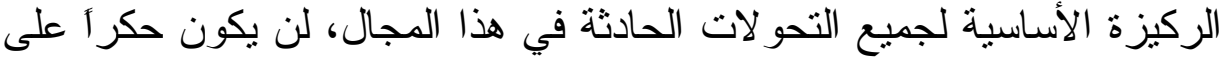

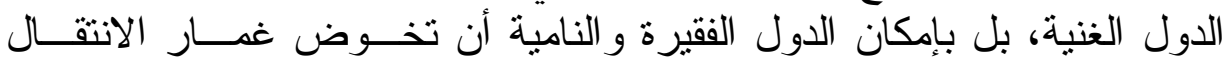

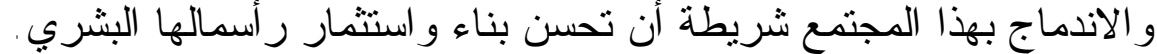

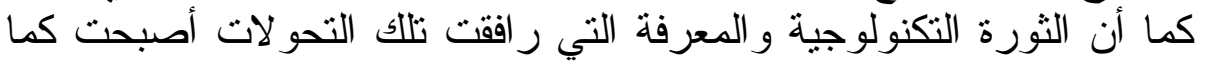

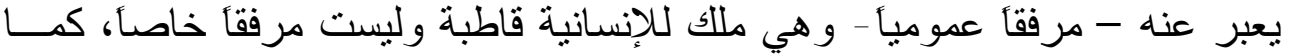

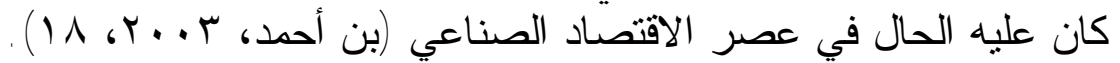


فالمعرفة المتولدة عن تلك التحو لات هي معرفة عامة الاتتماء بأغلب جو انبها

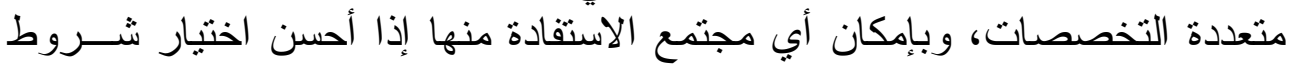

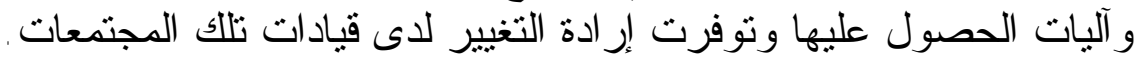

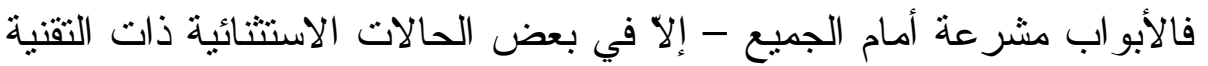

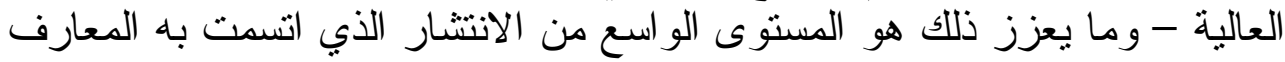

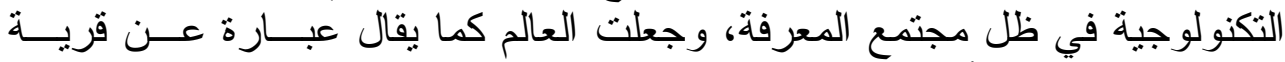

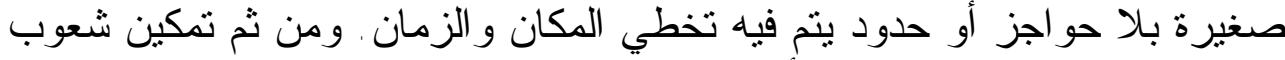

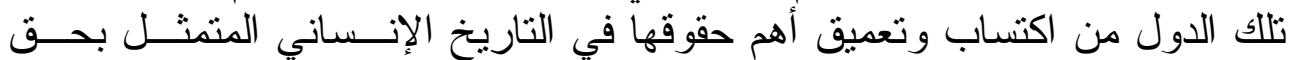
الإنسان في امتلاك المعرفة (http://ec.europa.eu).

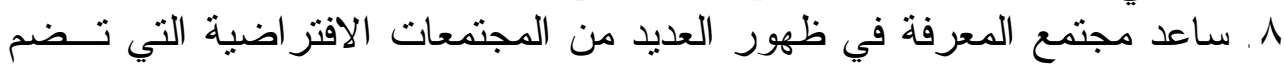

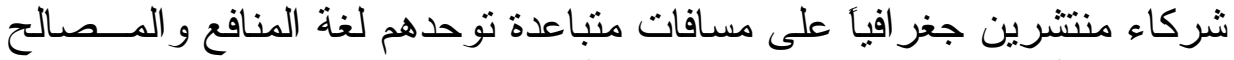

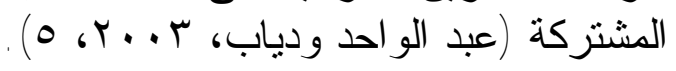

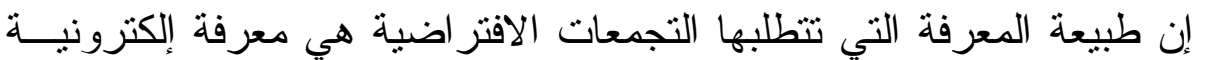

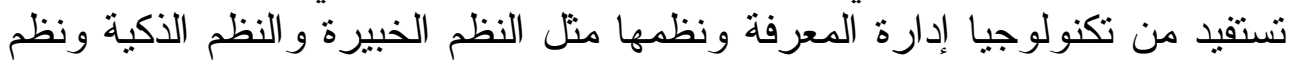

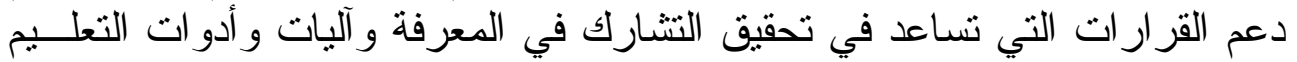

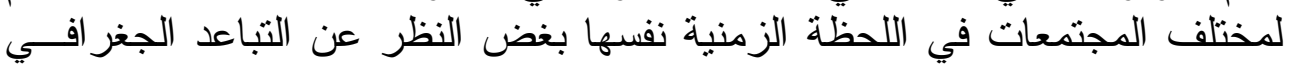
بين منتجي المعرفة ومستخدمئهيها.

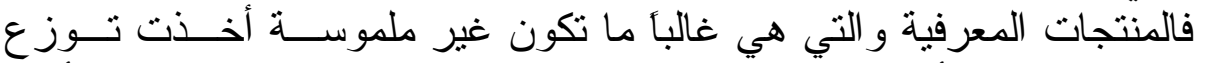

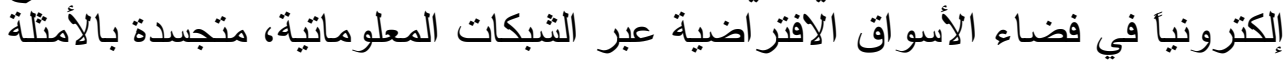

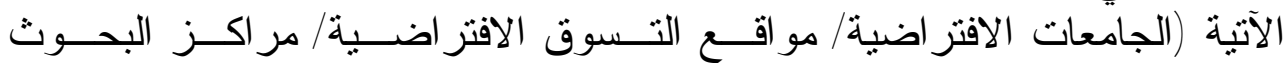

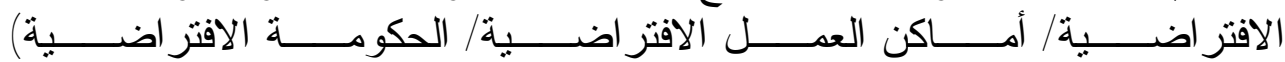
. (http://www.egovmonitor.com)

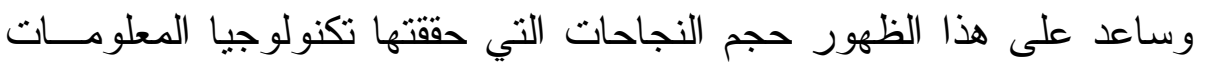

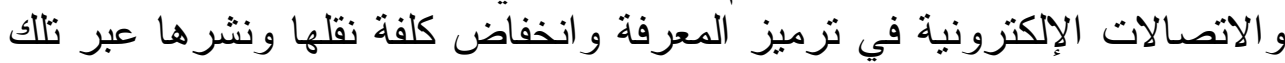

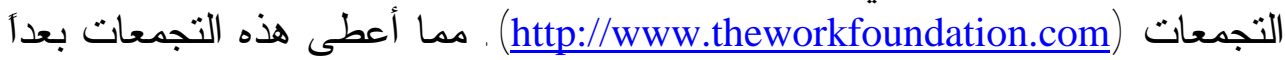

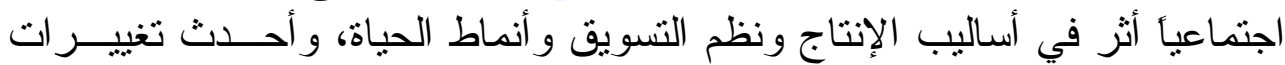

جذرية على مستقبل الاقتصاد العالمي (Economy print edition, Nov, 2001).

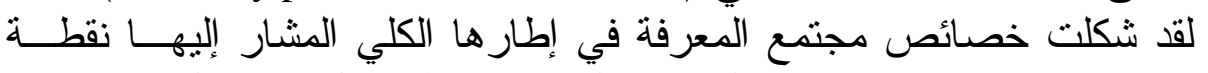

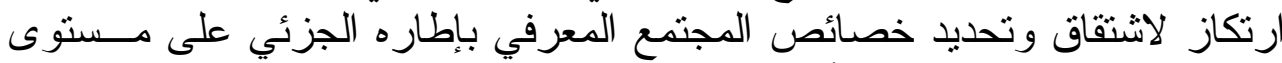

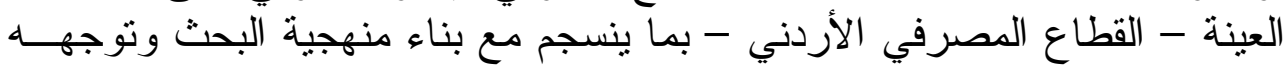

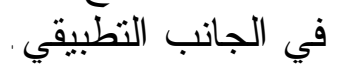

\section{مفهوم العمل المعرفي وعناصره}

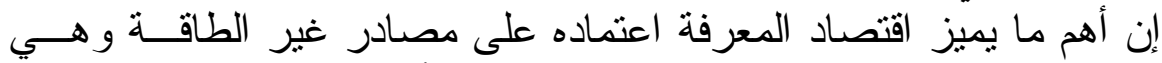

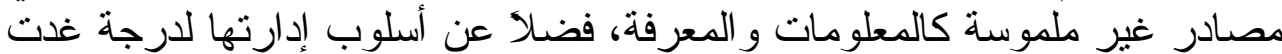


الدكتور العمري والدكتور السكارنة والحشاب [ ؛ 1]

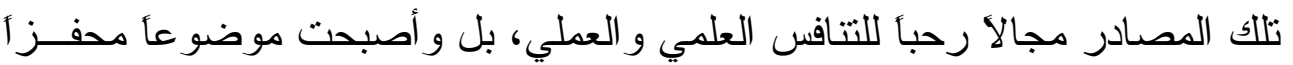
لمهن ووظائف مستقبلية في إطار المنظومة الاقتصادية العادية العامة.

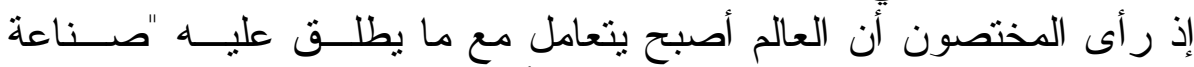

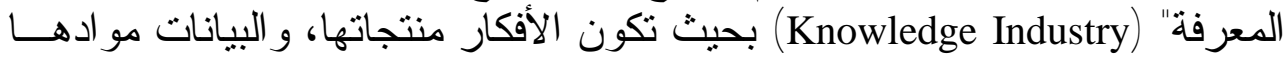

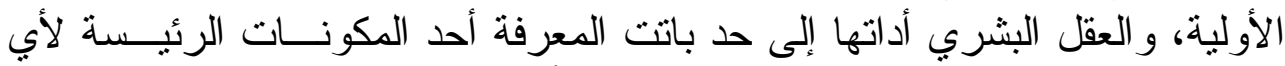

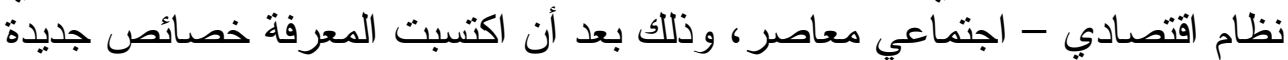

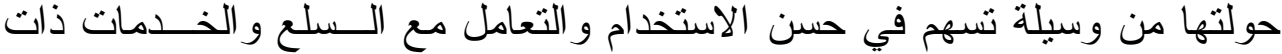

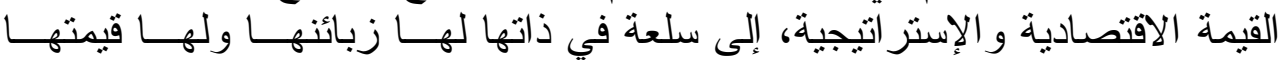

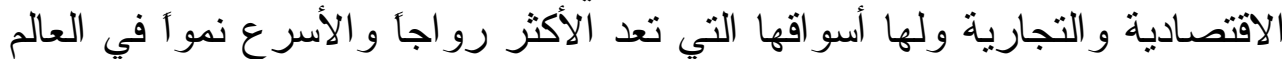

.(Drucker, 1994, 7)

خاصة بعد أن اتجهت صناعة التكنولوجيا حالياً إلى فصل المحتوى المعرفي

عن الجزء المادي الحامل لـــ (Cognitive content)

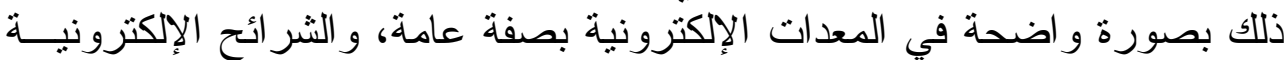

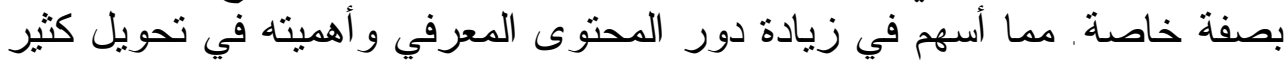

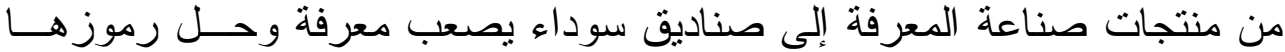

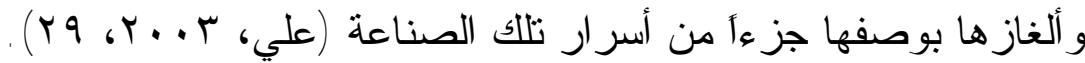

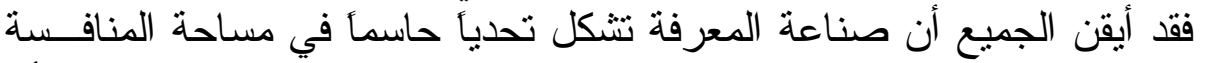

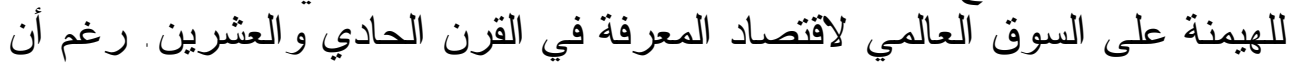

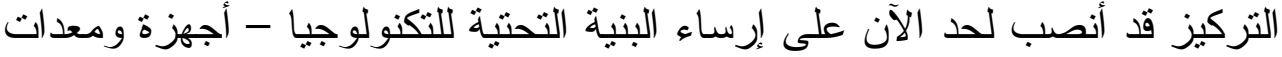

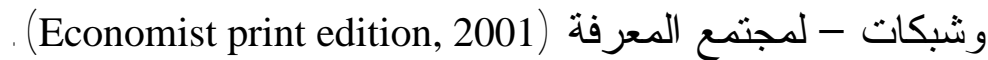
فقد ذكرت الإحصاءات بأن القرص المكتنز (CD) المنتج حالياً لا تشكل قيمة

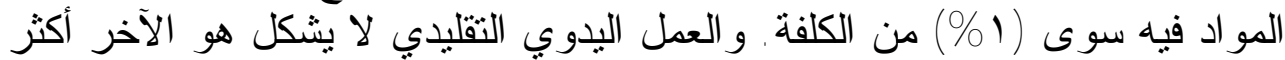

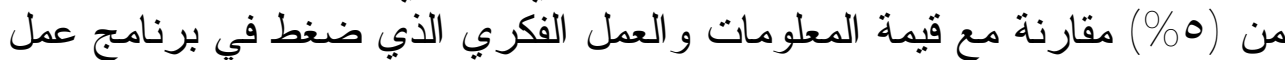

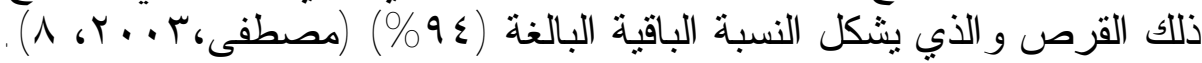
رافق هذا التطور في صناعة المعرفة بروز مصطلحين هما: العمل المعرفي

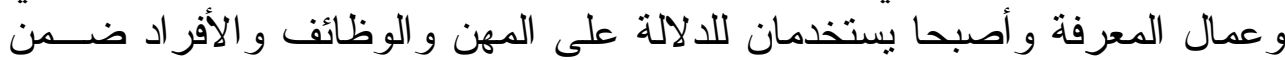

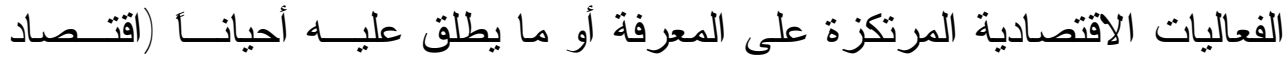

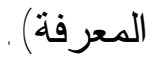

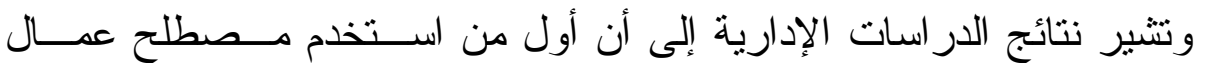

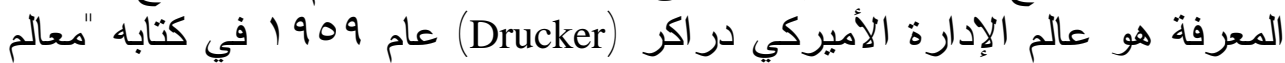

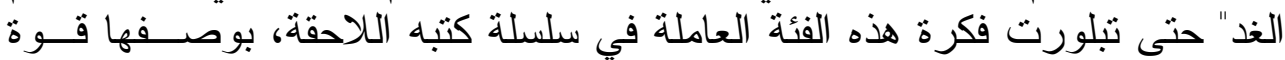
محركة ور ائدة في الاقتصاد الجديد القائم على المعرفة فلمة وفي الوقت ذاته فشله مشاركة في

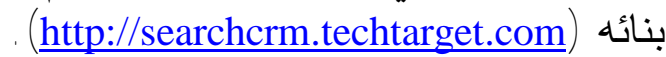
فعمال المعرفة هم تلاك الفئة من الأفر اد الذي يمارسون ما بــسمى بـالأعمـــال

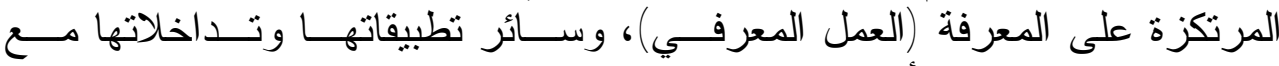

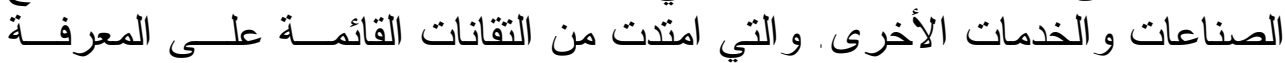


المكثفة (Hi - Tech) إلى تلاك التي تضم تقانة المعلومات و الاتــصالات (I - Tech) . (http://navcenter.borgess.com)

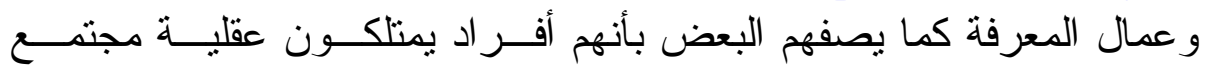

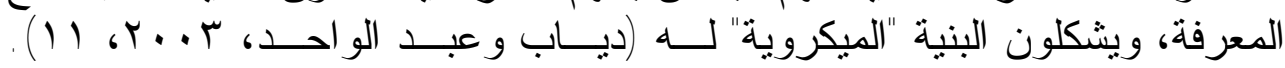

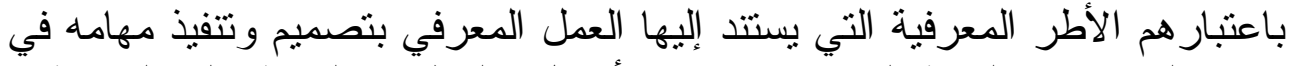

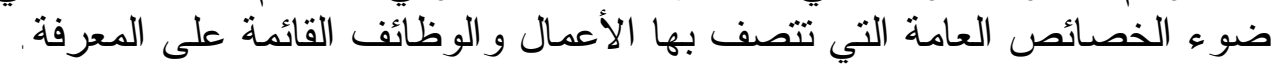
و لأغر اض البحث فإن الثركيز سيكون على تصميم العمل المعرفي من خلال عناصره الرئيسة الثناثة وهي:

\section{أولاً - الهيكل الوظيفي للعمل المعرفي}

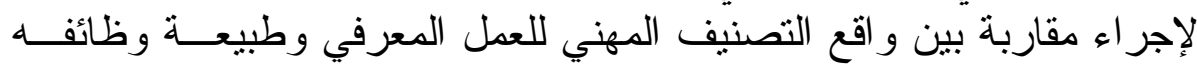

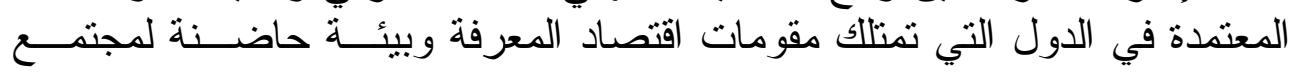

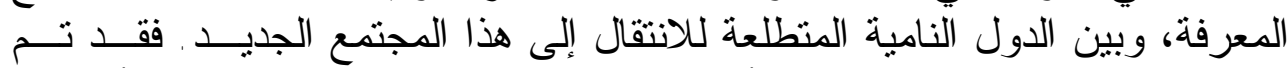

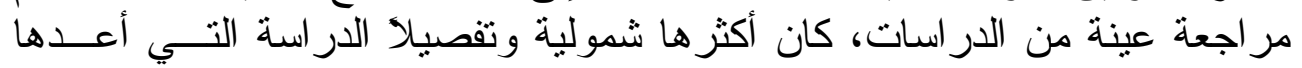

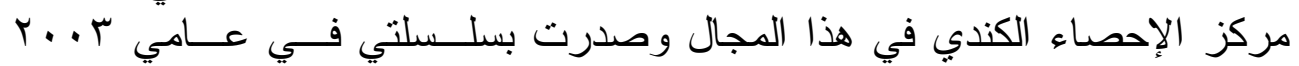

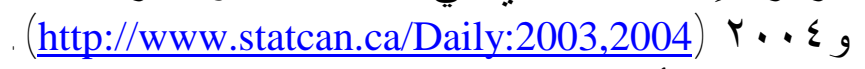

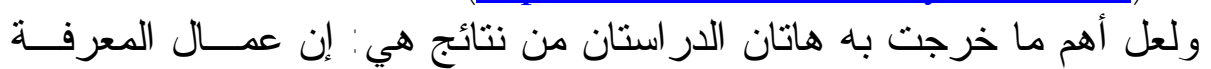

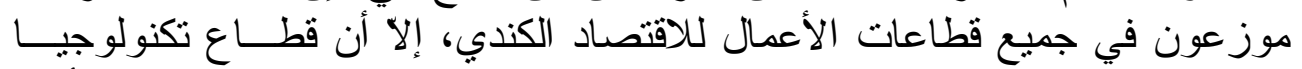

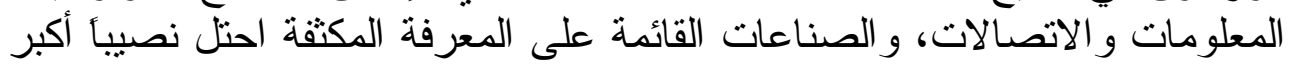

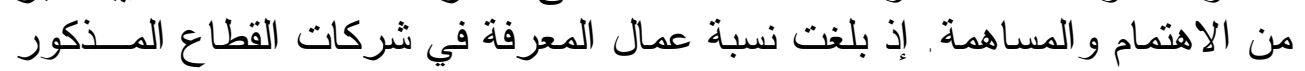

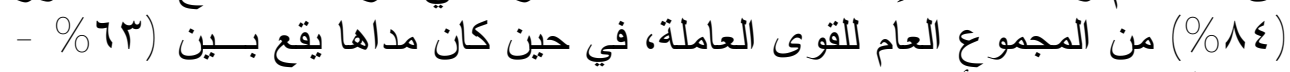

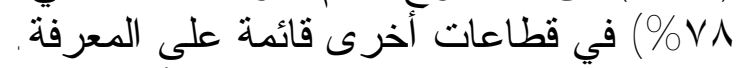

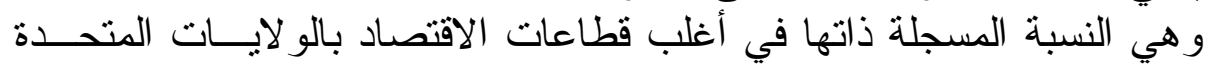

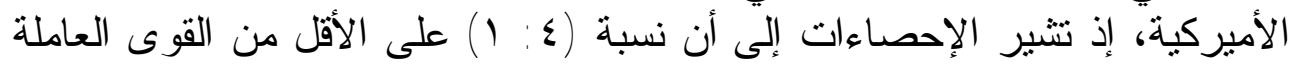

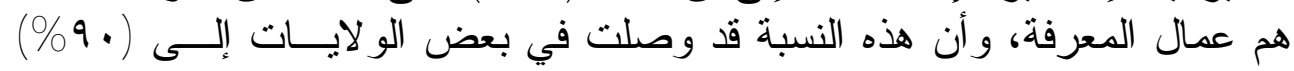

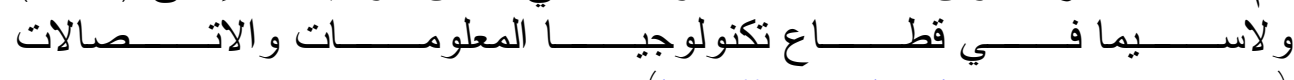
.(http://www.developmentgateway.org)

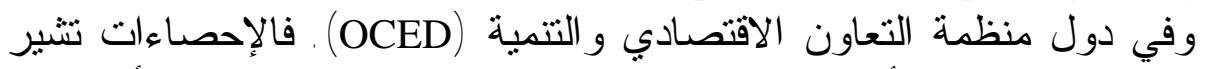

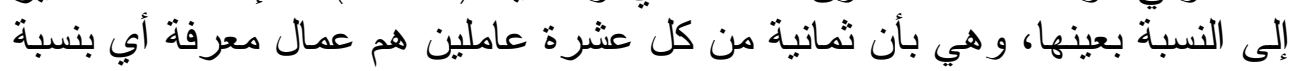

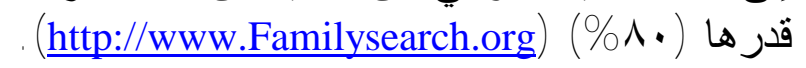

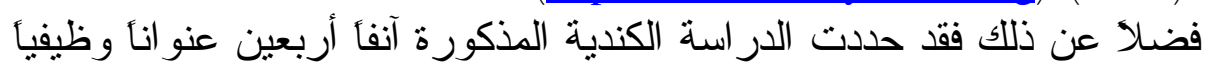

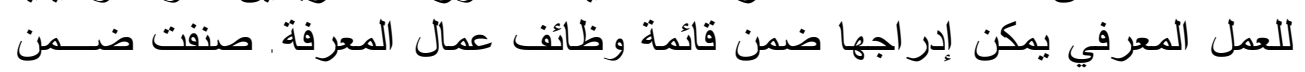

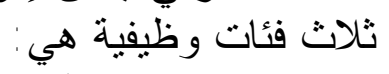

\section{1. الاختصاصيون (Professional Occupations)}

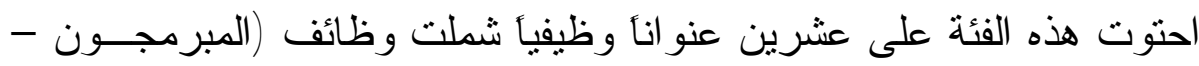

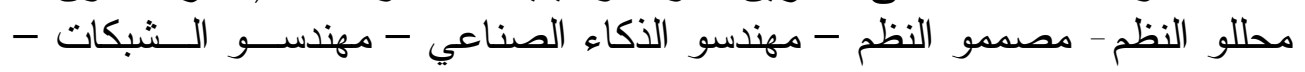


الدكتور العمري والدكتور السكارنة والحشاب [4 ؛ 1]

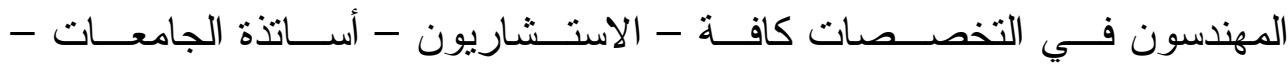
الاختصاصيون في العلوم الطبيعية و الصرفة - التخصصات الطبية) . وهم يشكلون التهات

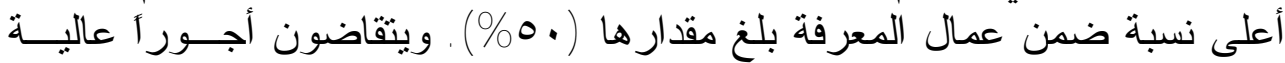

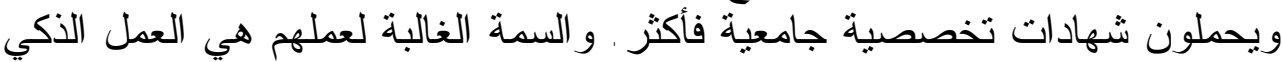
(Intelligent Work) تطبيقاتها.

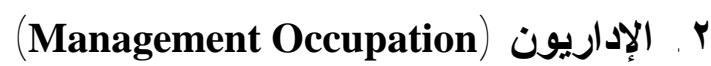

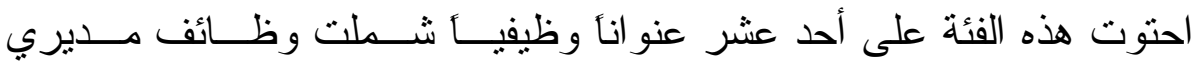
الوحدات الإدارية الرئيسة (في مجالات الإنتاج/ التسويق/ الماتئة المالية/ الموارد البشرية/

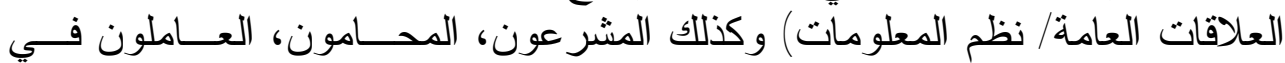

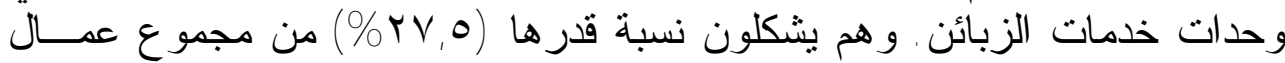

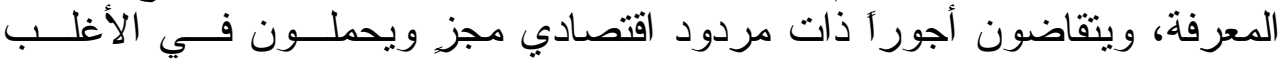
شهادات جامعية. و السمة الغالبة لعملهم هي العمـــل الإداري (Managerial Work ).

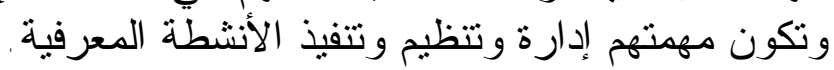

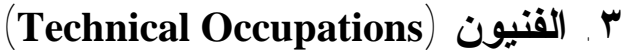

احتوت هذه الفئة على تسعة عناوين وظيفية شملت التخصصات الفنية كافــة (الهندسية- الطبية - الإدارية - الزر اعية - النقل .. الخ) . وهم يشكلون نسبة قدرها

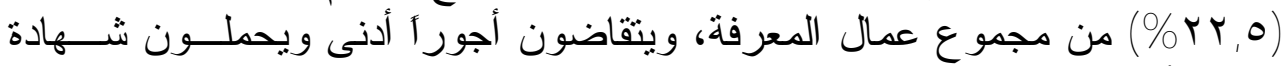

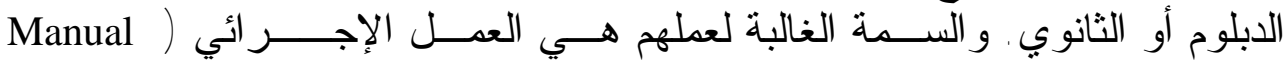

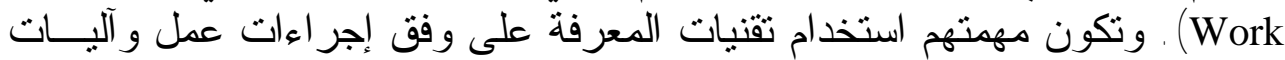
محددة ضمن تخصصاتهم الفنية. لقد بينت الدراسة ومن خلال الأرقام التي أثنير إليها بأن هناك حالة استقطاب

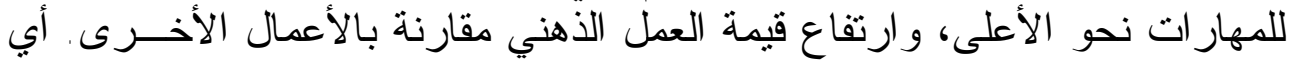

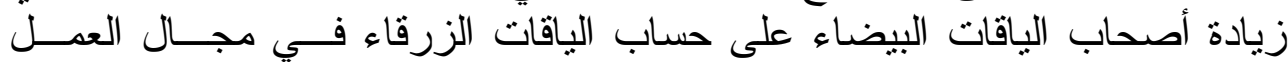

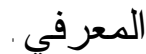

ويستتتج مما تقدم بأن هرم العمالة لا ينطبق بمعاييره التقليدية (الذي تكـــون

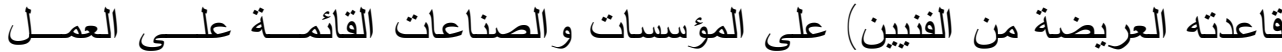

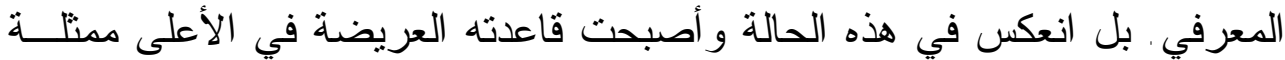
بالفئة الأولى من الاختصاصين، تليها الفئة الثانية من الإداريين، و آخر ها الفئة الثالثة

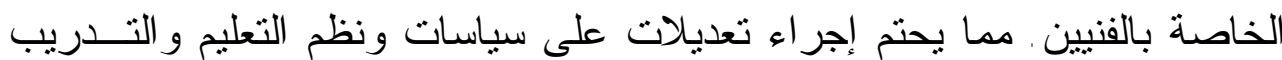
خاصة المتقدمة منها ذات العلاقة بعملية الاستثمار المعرفي و إعداد وتتمية الموارداد

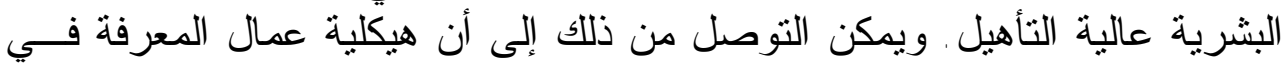

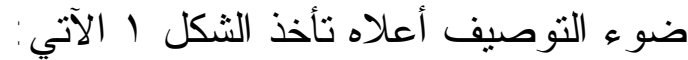




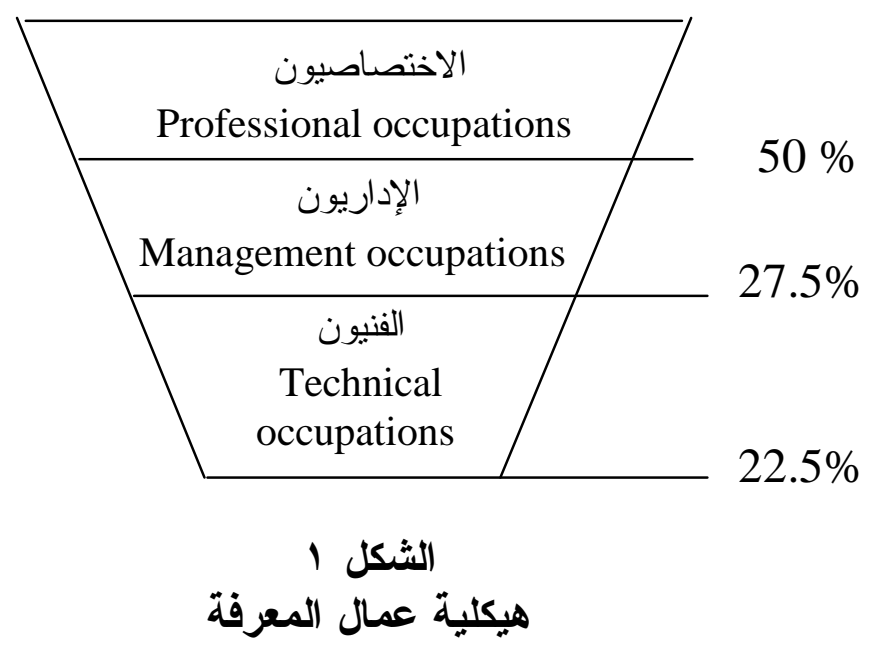

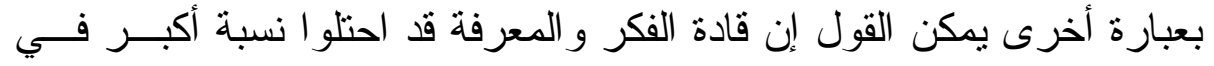

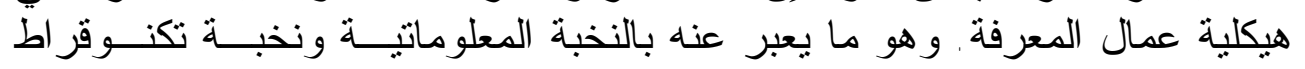

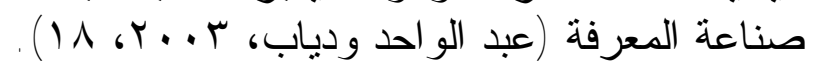

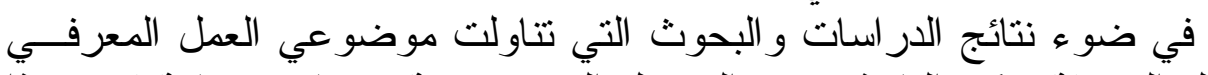

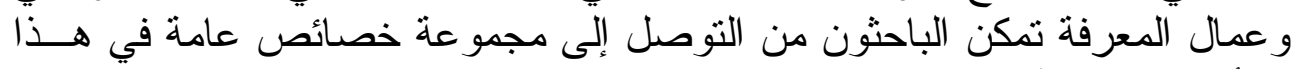

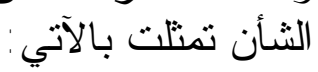

1 ـ الميل لإشباع الّاجات العليا (المتقدمة) على حساب الحاجات الأساسية

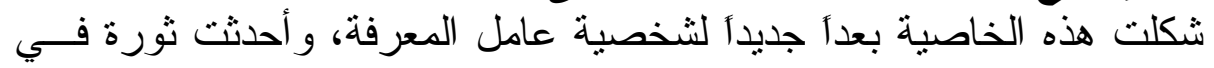
مفاهيم نظرية ماسلو حول "الدو افع الثخصية في العمل" وسلم الحاجات الذي بندي علئي إذ تبين بأن عمال المعرفة لديهم في الغالب الثعور الدائم بالمتعة في إنجــاز

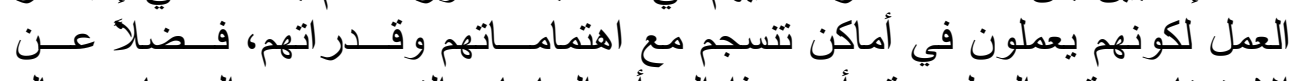

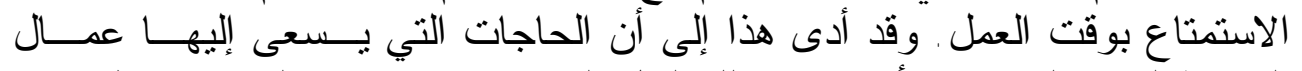

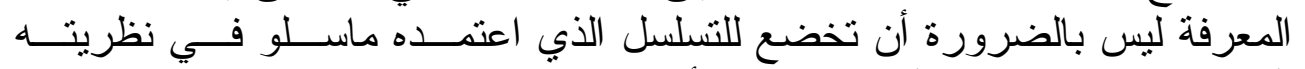

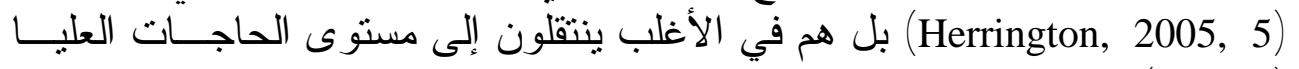

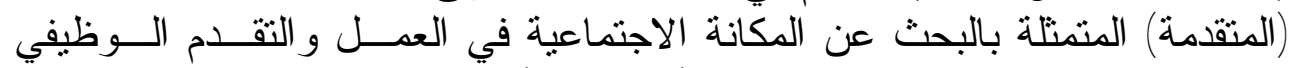

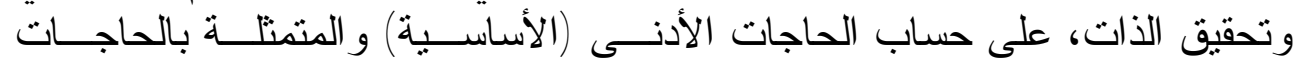


الدكتور العمري والدكتور السكارنة والحشاب [N؛ 1]

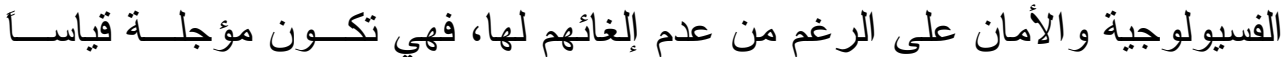

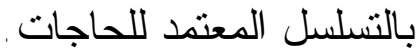

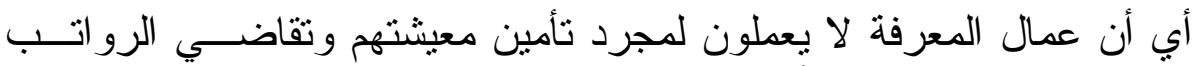

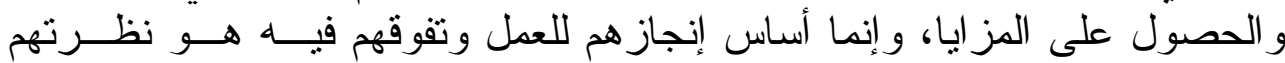

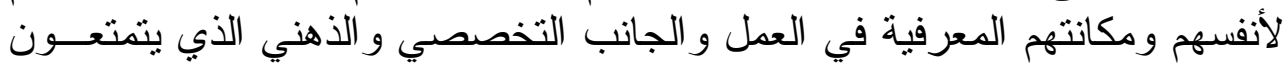

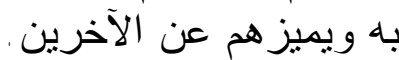
ويرجع هذا في تقديرنا إلى إن ارتباط عمال المعرفة بالعمل يينى بالأســاس الزاس

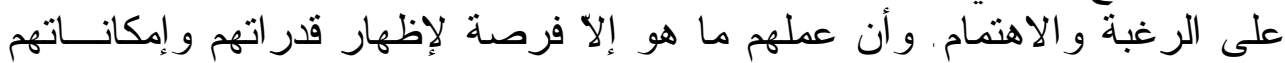

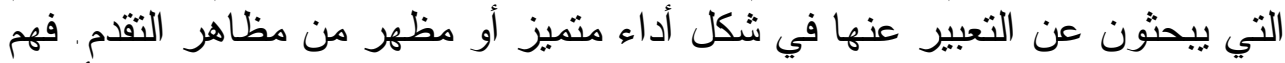

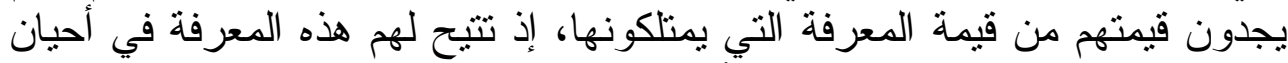

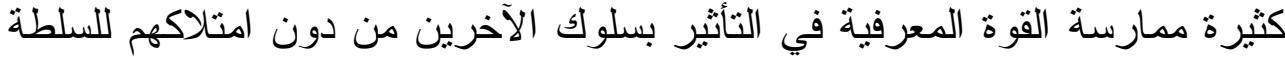

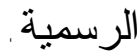

لهذا نجد بأن هذا التطور قد أحدث استثاءً يجب الإقرار به عند الرجو ع إلى لى

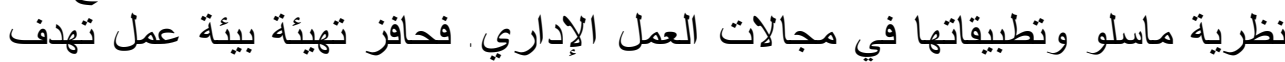

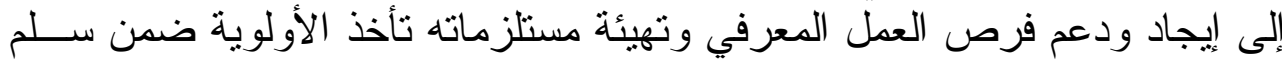

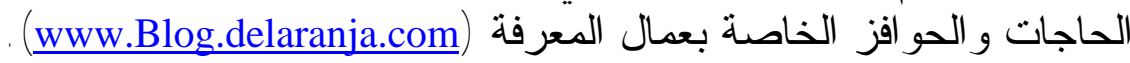

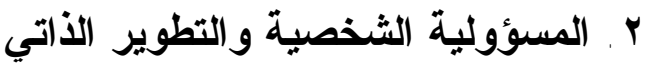

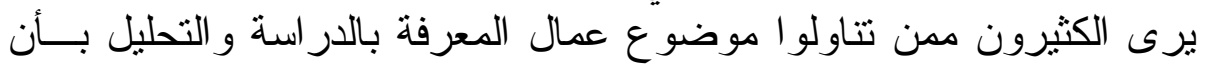

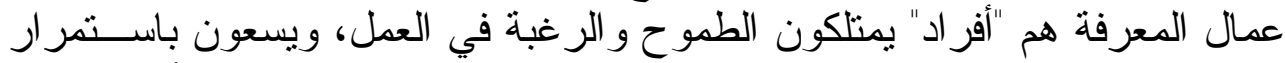

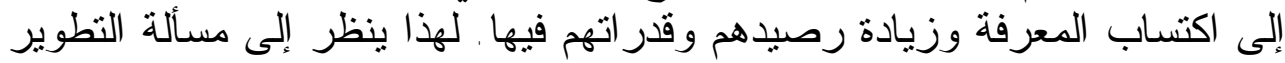

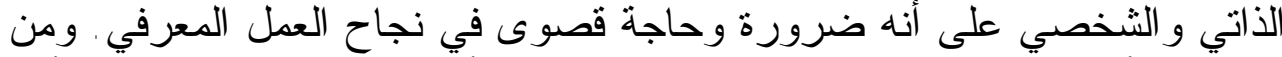

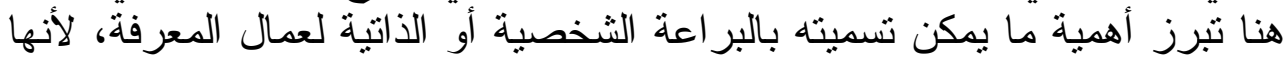

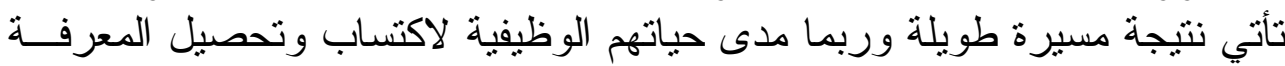

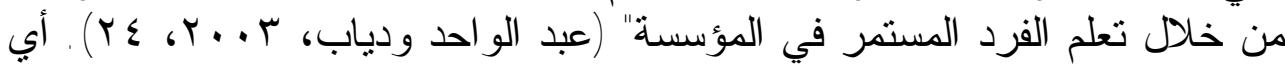

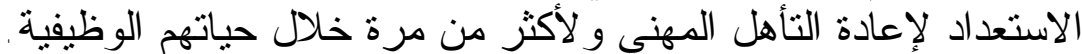

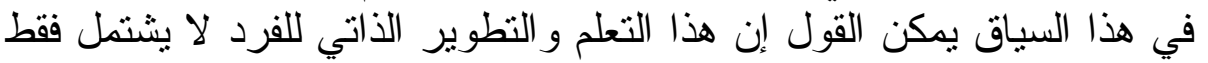

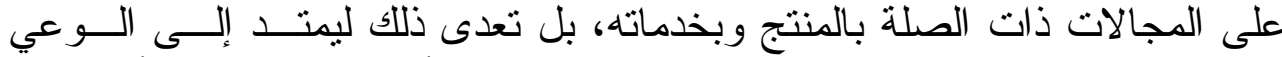

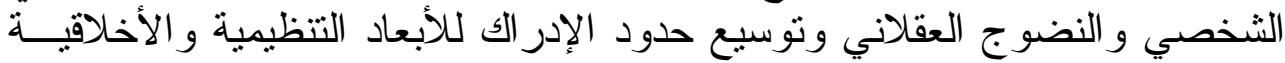
إذ نجد أن هذا النوع من البر اعة الثخصية يقود الفرد إلى تقــيم مـسـاهمة

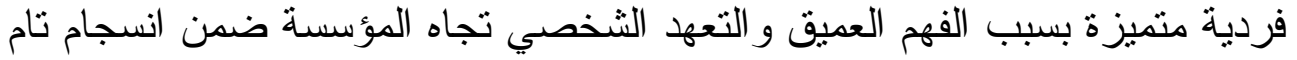

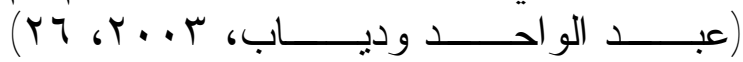
. (http://blogs.ittoolbox.com) يؤدي ذللك إلى نشو هو حوافز ذاتية للوصول إلى مستويات أعلــى فـــي الأداء

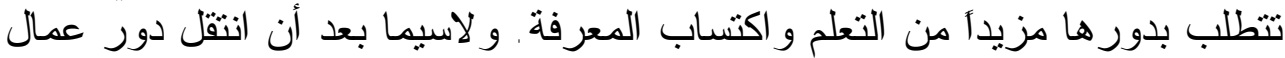


المعرفة من إطار تتفيذ أعمال بسيطة متحكم بها إلى انجاز أعمال معرفية معقدة، إذ إذ إنها

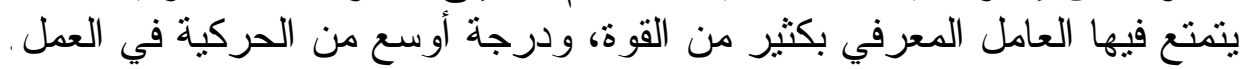

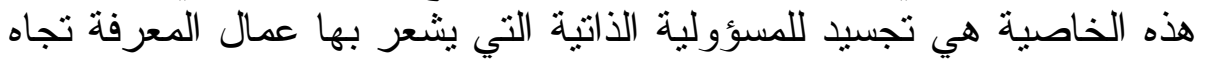

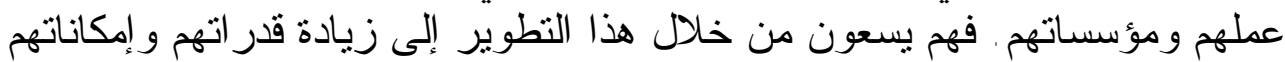

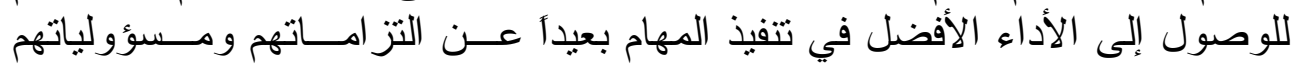

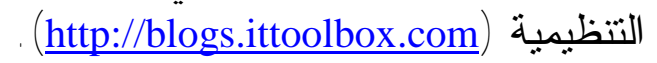

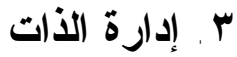

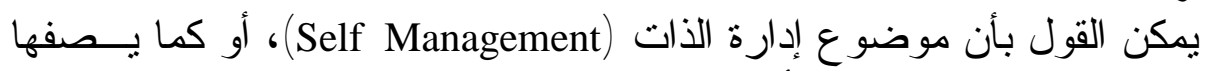

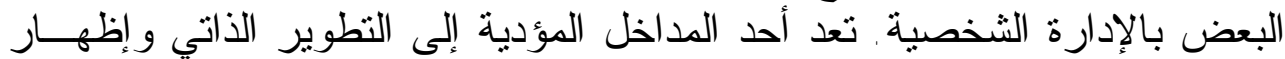
الثخصية المستقلة لعمال المعرفة.

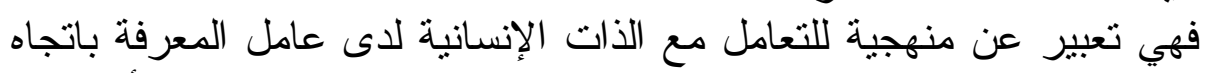

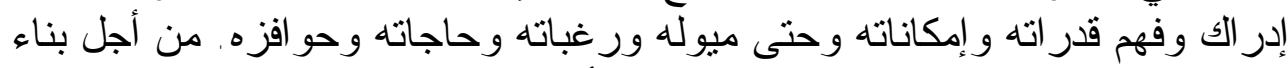

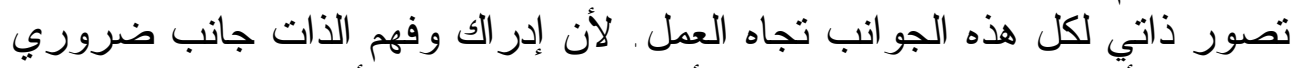

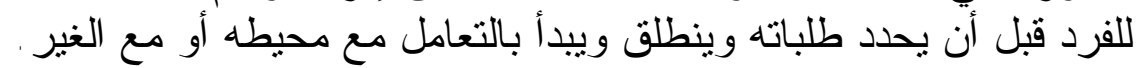

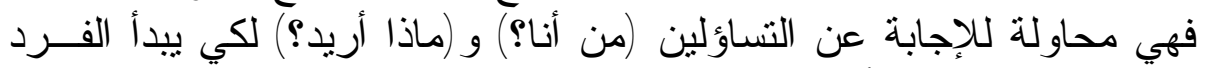

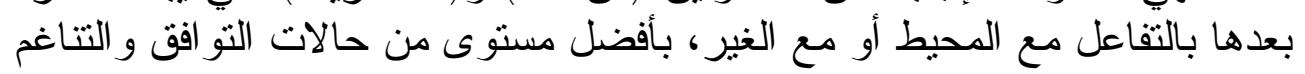

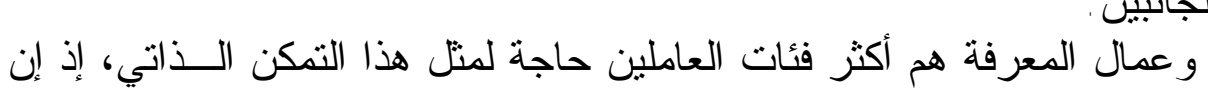

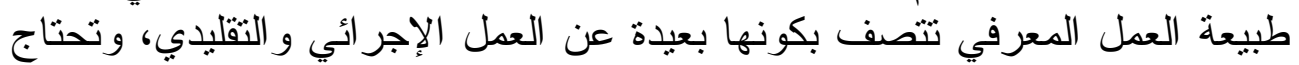

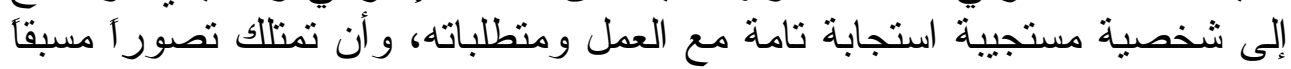

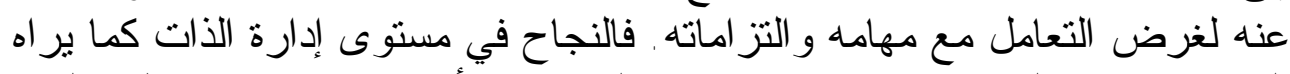

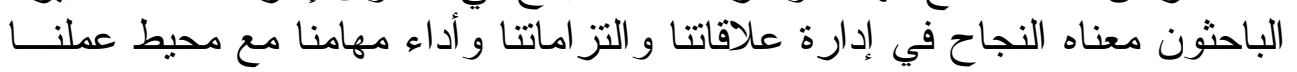
إن المتتبع لممارسة إدارة الذات يجد بأنها لا تختلف عن أوجه النشاط الإداري

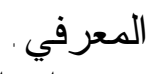

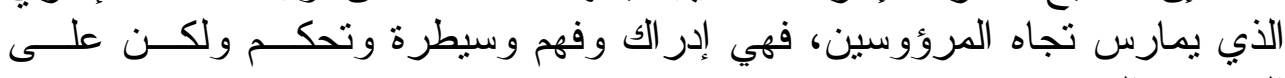

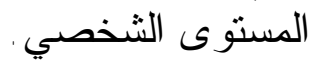

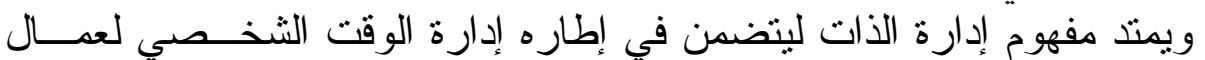

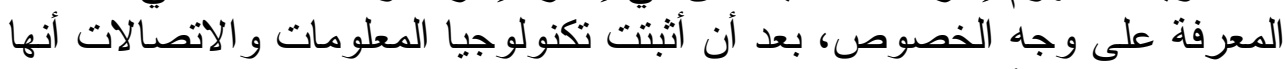

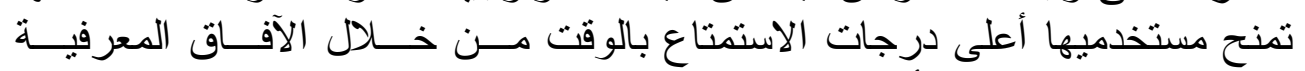

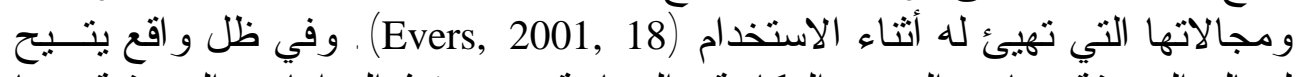

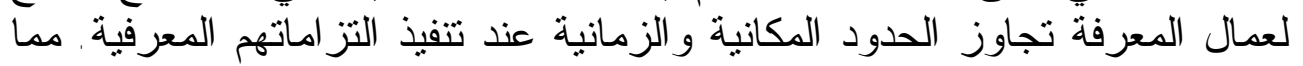

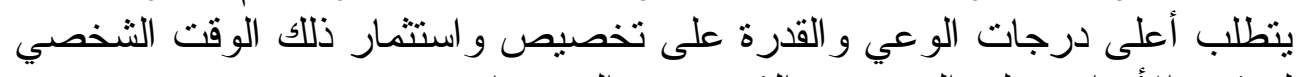

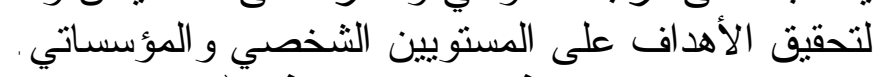

؛ ـ المنهج التثاركي في العمل المعرفي (Sharing of knowledge work)

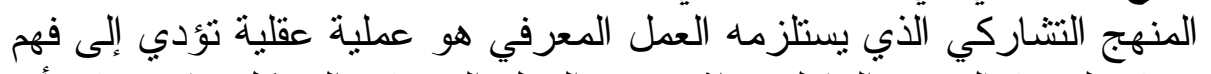

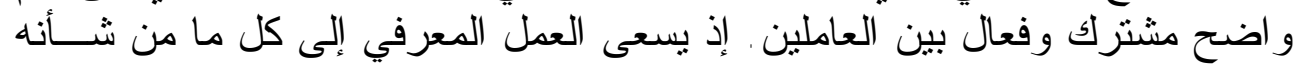


الدكتور العمري والدكتور السكارنة والحشاب [0] [10]

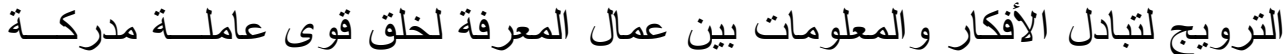

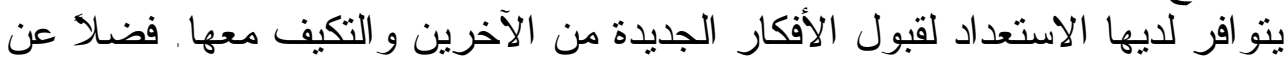

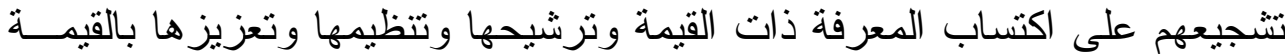

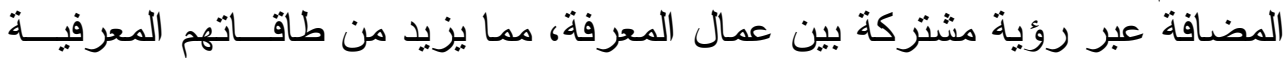

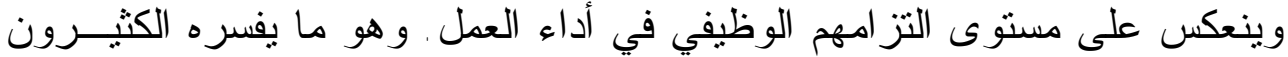

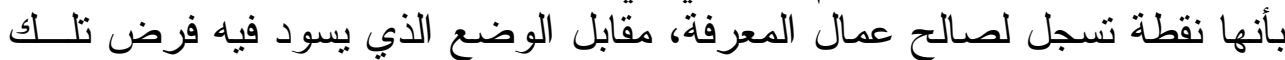

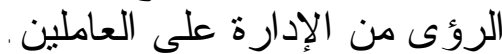

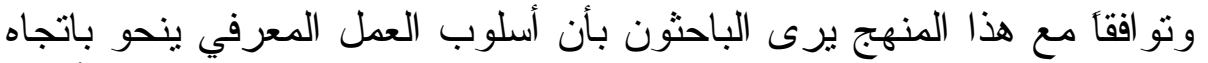

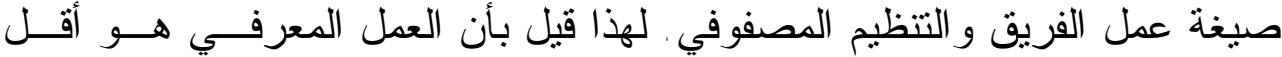

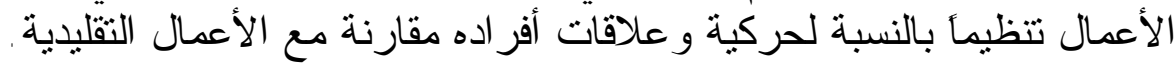

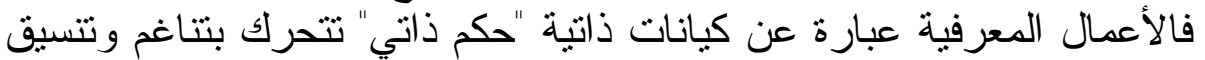

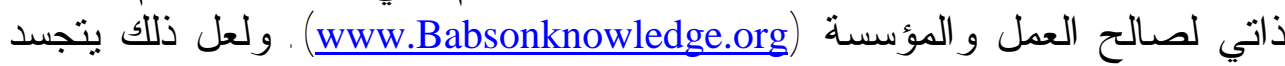
جيدأ في فكرة التمكين (Empowerment) التي تخول هؤ لاء العهال القوة و الــسلطة

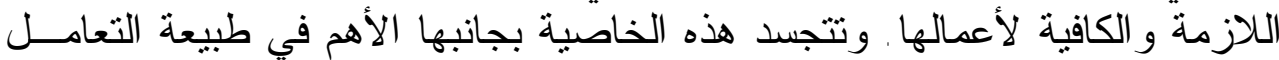

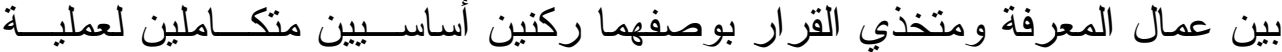

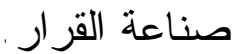

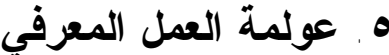

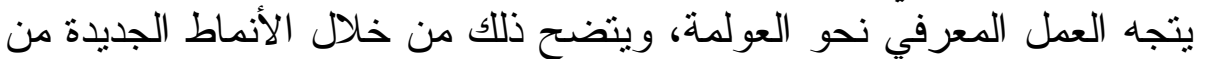

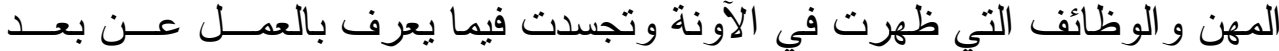

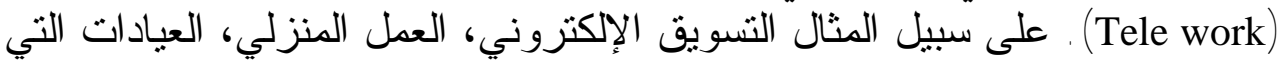

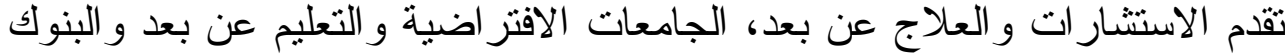

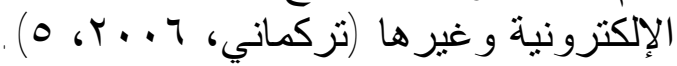

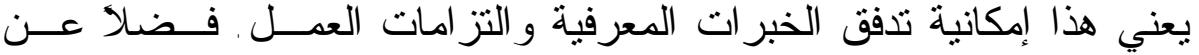

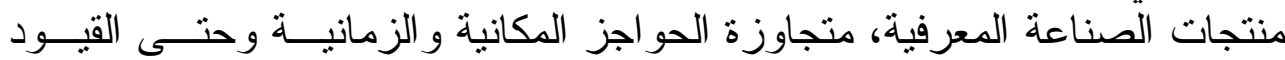
القانونية أحياناً.

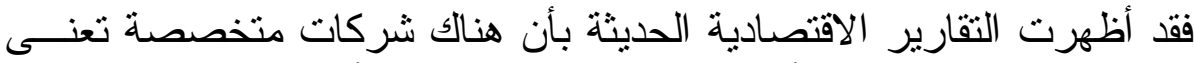

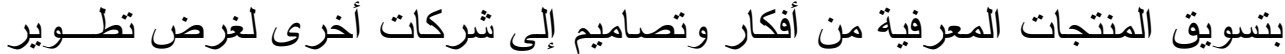

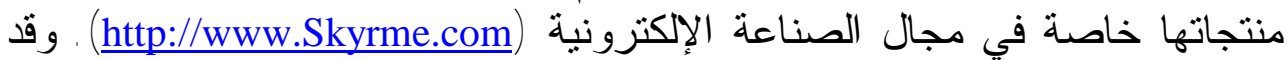

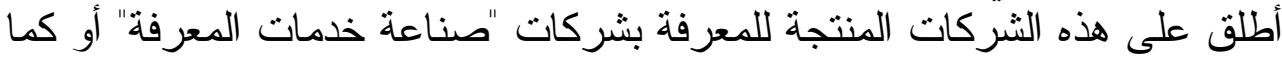

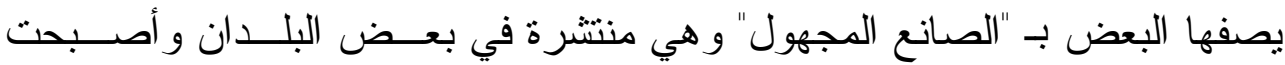
ميزتها التتافسية كالهند مثلا.

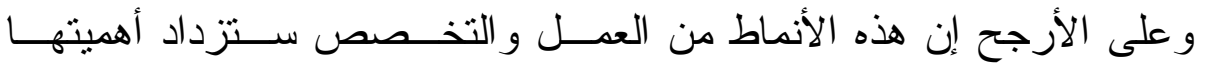

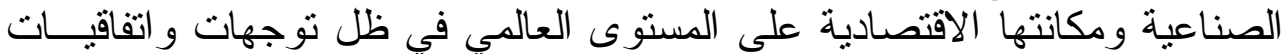

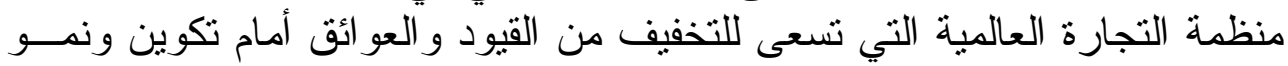

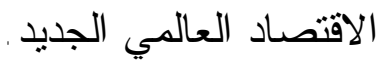




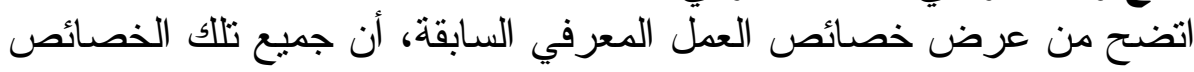

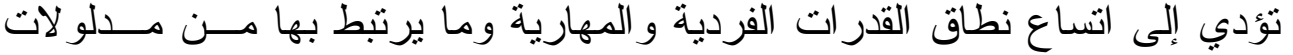

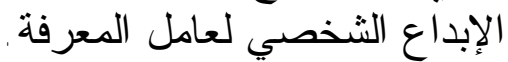

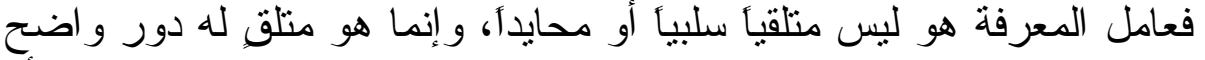

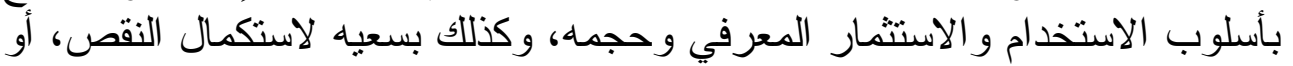

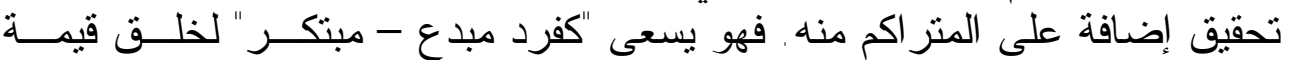

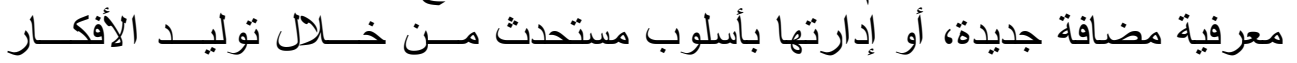

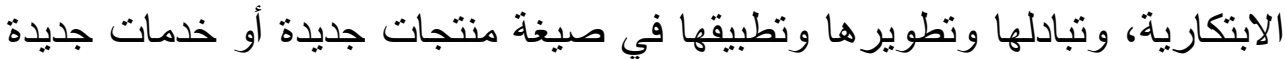

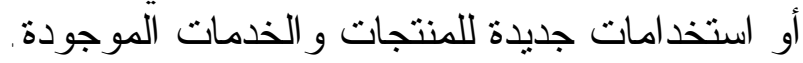

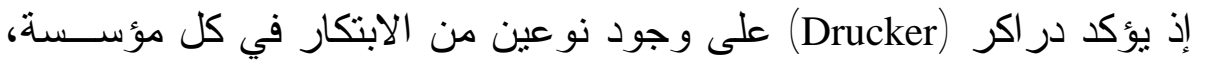

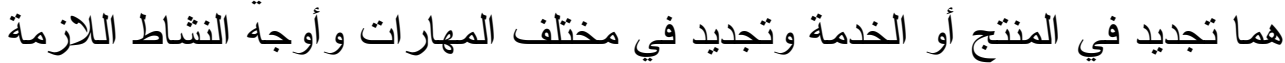

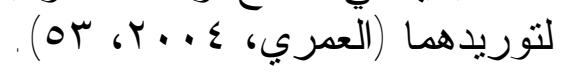

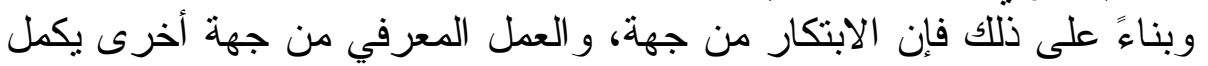

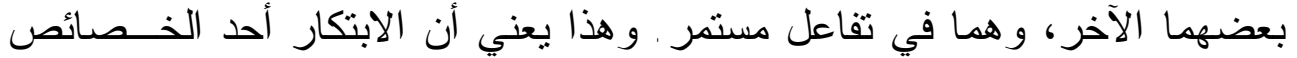

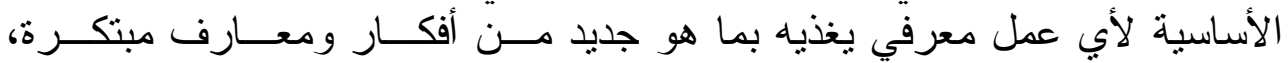

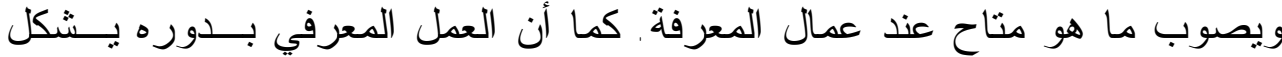

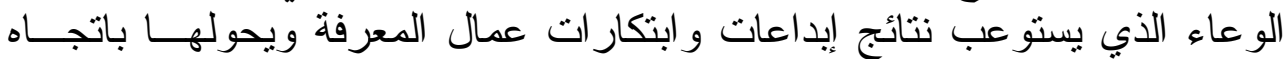
غاياتها المحددة لها. لهذا يمكن النظر إلى العمل المعرفي بأنه منظومة مصغرة للإبداع و الابتكـــار

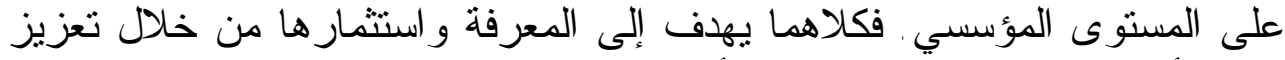

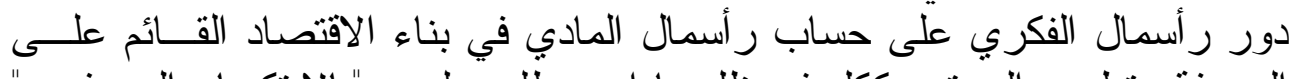

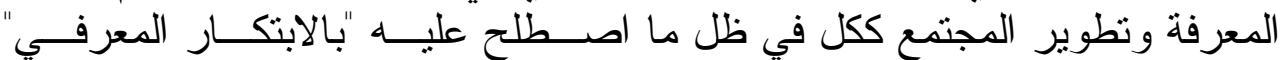

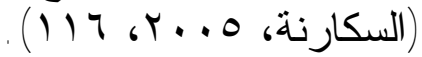

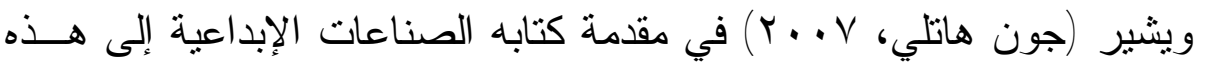

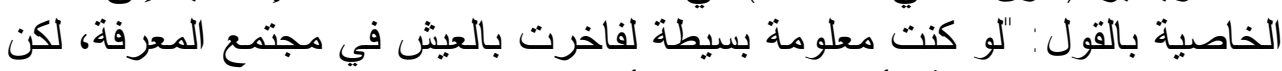

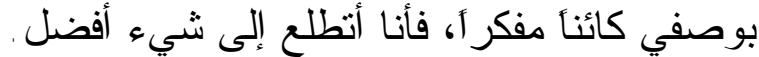

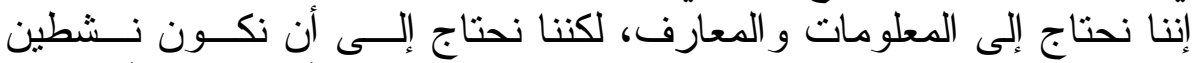

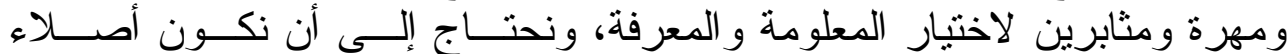

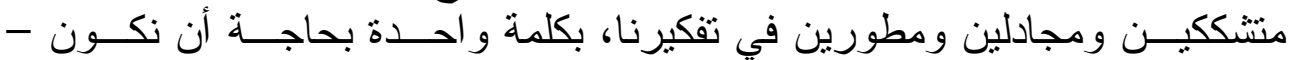
مبدعين -"، وعليه فإننا نجد بأن العمل المعرفي ما هو بـا وإلا عمل إبداعي - ابتكاري.

(Soft skills) ثالثاً - المهارات المعرفية)

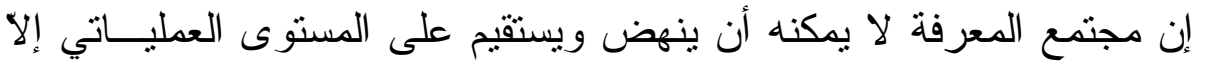

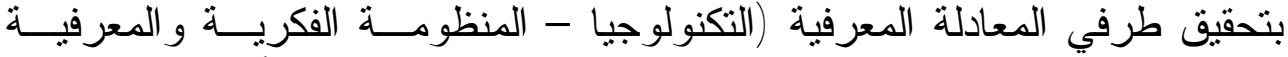
للعاملين)، لذللك تتطلع المؤسسات القائمة على المعرفة باستقطاب أفر اد من عمـــال 
الدكتور العمري والدكتور السكارنة والخشاب [10 [10]

المعرفة يكون بمقدور هم القيام بأداء منتوع وو اسع مــن الأعمــال عبـر المـسـار

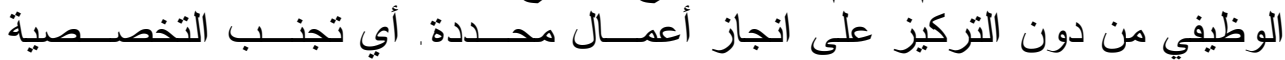

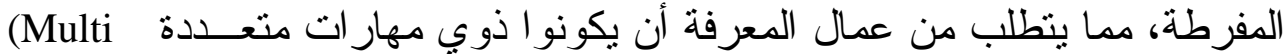
(. skills) (Hard skills)

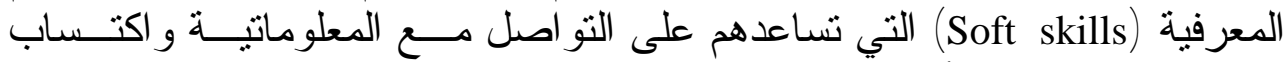

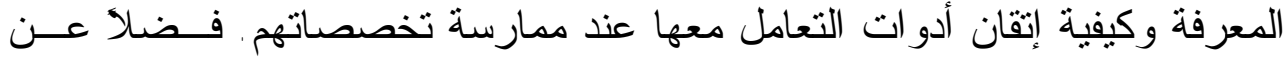

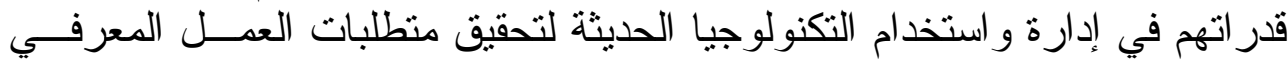
. (http://www.jpa.gov)

وبناءً عليه؛ فقد ازداد مستوى الطلب على المهار ات المعرفية و لاسيما بعد ما

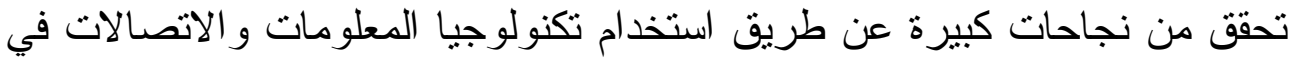

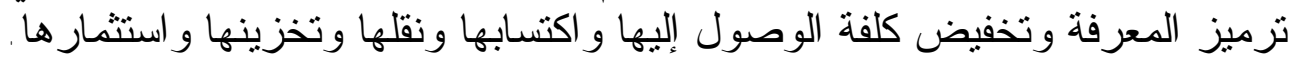

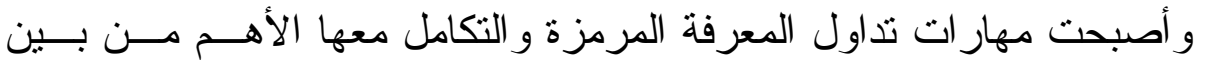

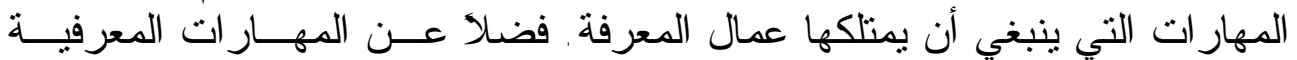

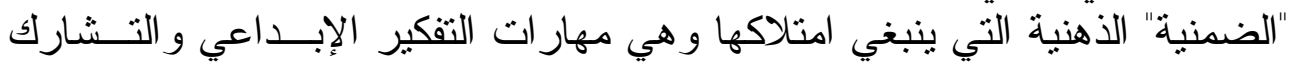

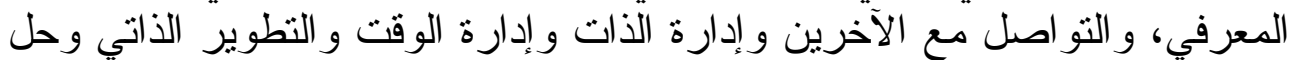

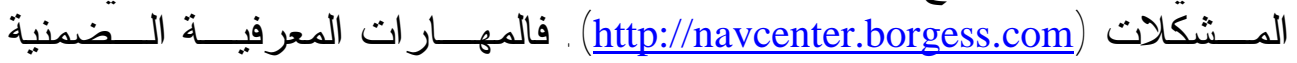
المذكورة و غير ها تعد أداة تمكين لعمال المعرفة في تتمية قدر اتهم الذهنية ومو اجهة

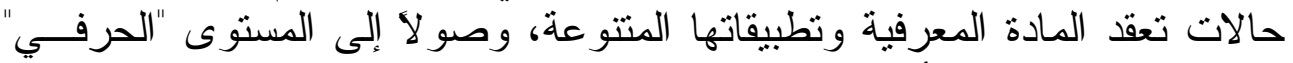

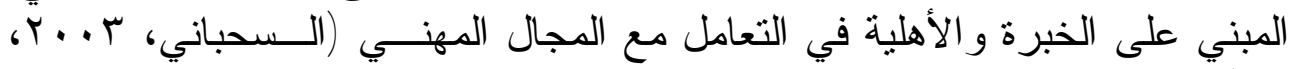
(1)

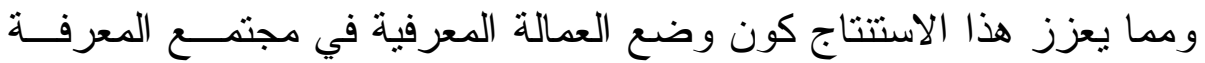

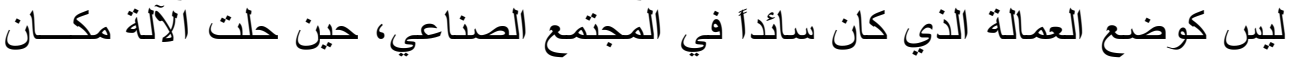

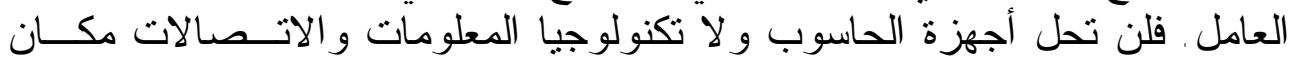

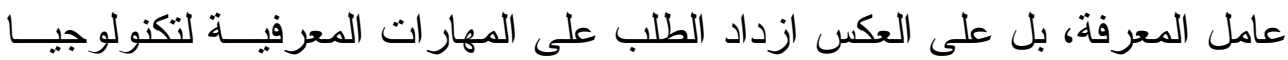

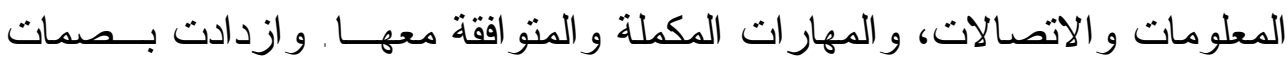

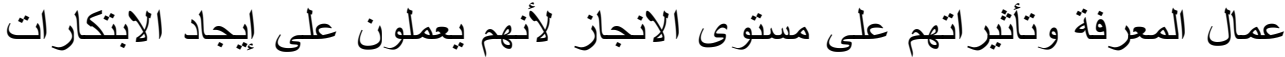

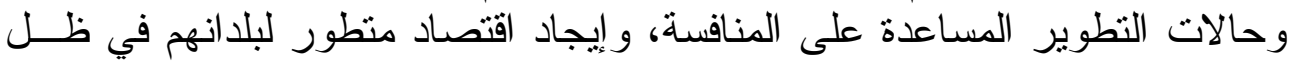
عولمة السوق (Riley, 2003, 5) . وملخص القول أن المهار ات المعرفية في ضوء أنوا، التوصيف و المحتوى المشار

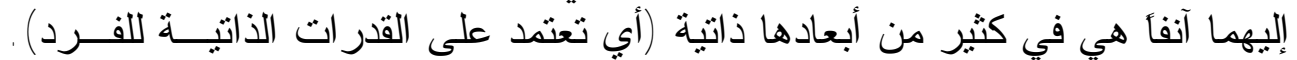

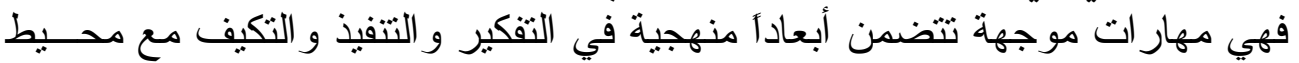

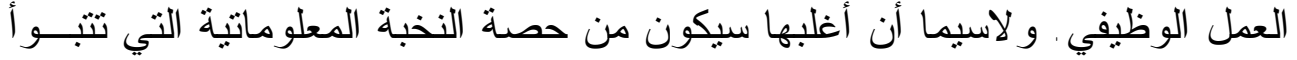

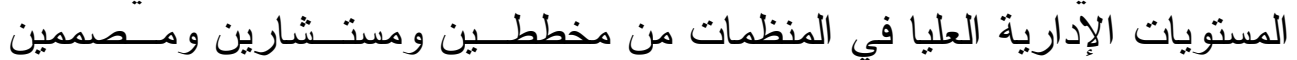

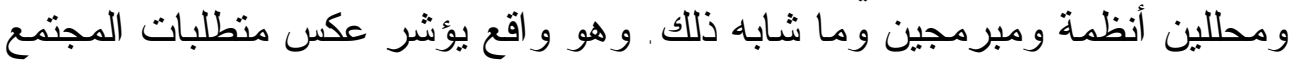

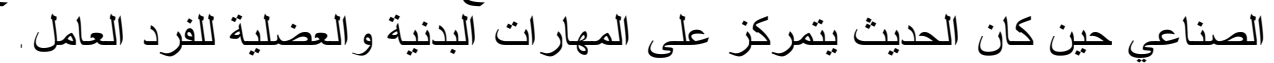




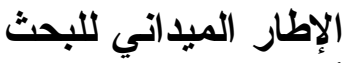 \\ أولاً - وصف خصائص المينة البحث}

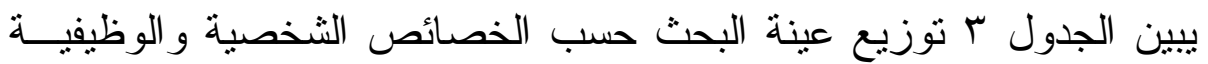

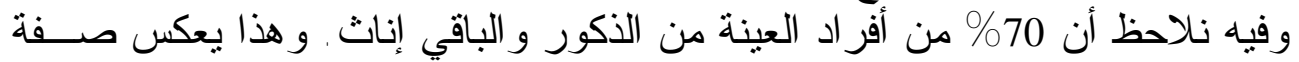

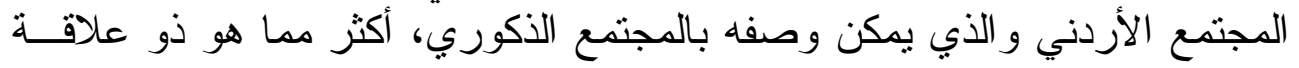

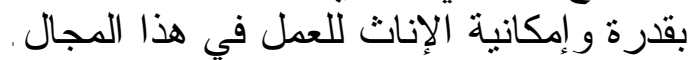

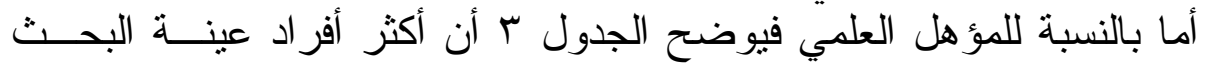

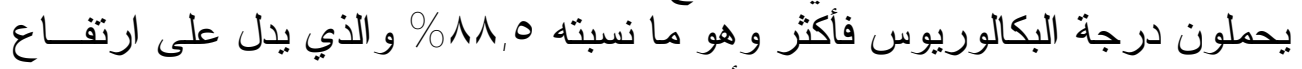

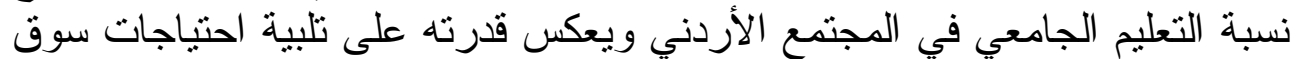

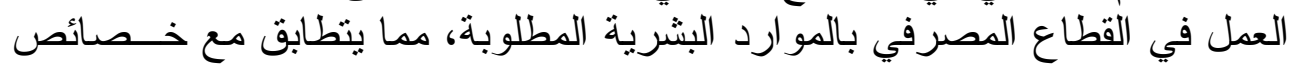

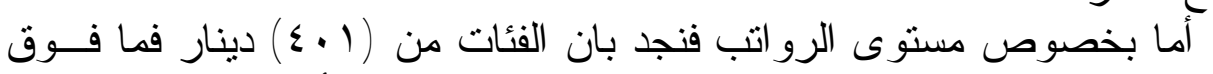
مجتمع المعرفة.

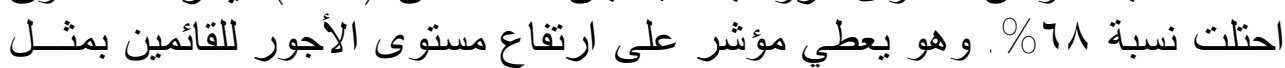

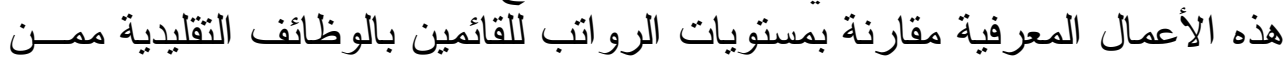

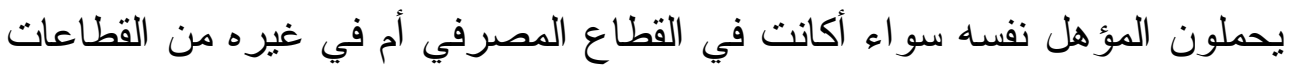

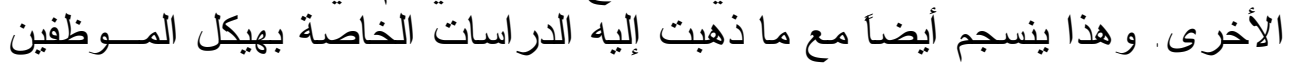

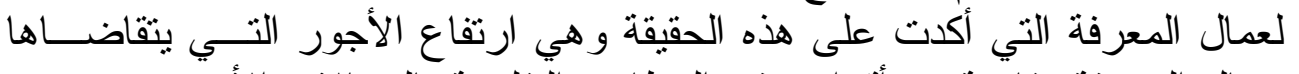

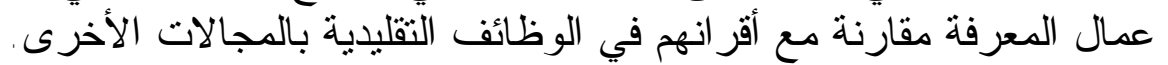

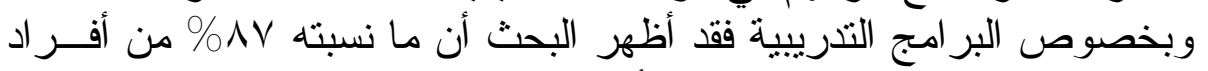

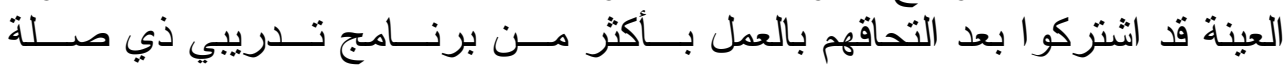

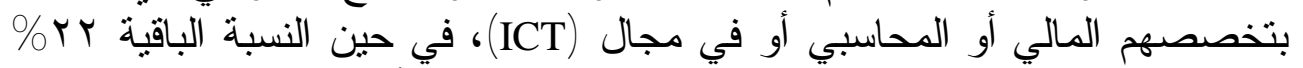

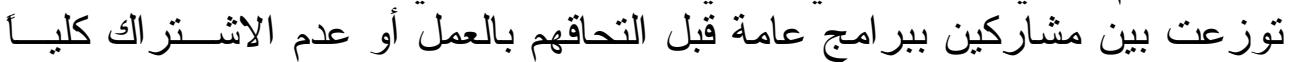

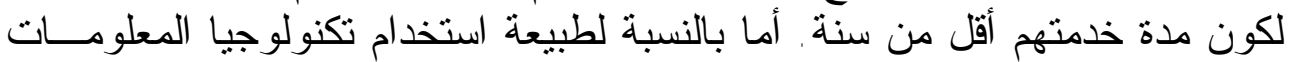

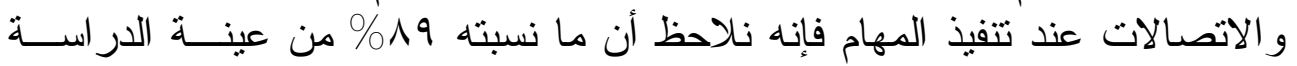

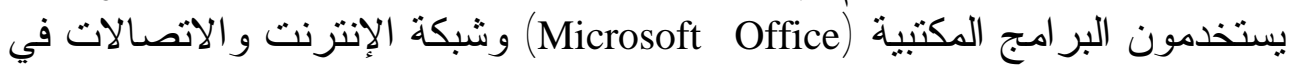

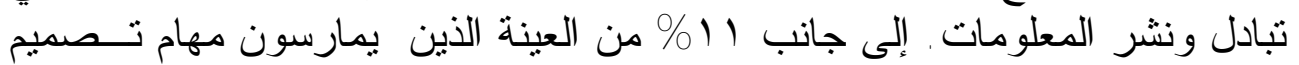

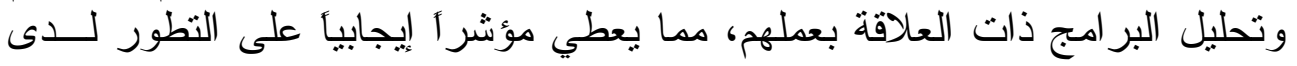

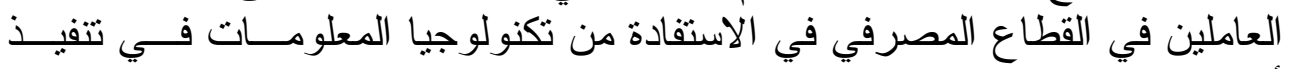


الدكتور العمري والدكتور السكارنة والحششاب [ـه 1]

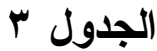

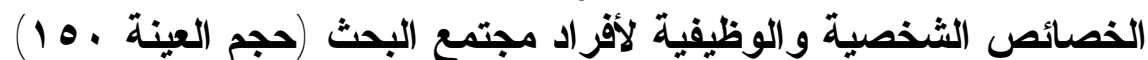

\begin{tabular}{|c|c|c|c|}
\hline النسبة المئوية & التكرار & \multicolumn{2}{|c|}{ المتغير ات الوظيفية و الثخخصية } \\
\hline$\% \vee$. & 1.0 & ذكر & \multirow[t]{2}{*}{ 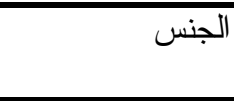 } \\
\hline$\% r$. & 纟o & أنثى & \\
\hline$\% 1 \ldots$ & 10. & 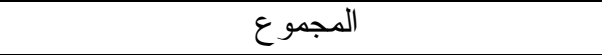 & \\
\hline$\% r, 0$ & o & ثانوي & \multirow{4}{*}{ المؤهل العلمي } \\
\hline$\% \wedge$ & ir & دبلوم & \\
\hline$\% \wedge 0$ & IrA & جامعي & \\
\hline$\% r, 0$ & 0 & ماجستير & \\
\hline$\% 1 .$. & 10. & 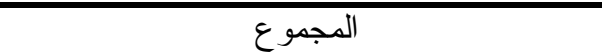 & \\
\hline$\% \backslash r, \varepsilon$ & $\bar{r}$. & 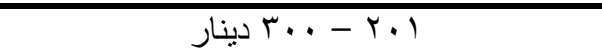 & \multirow[t]{4}{*}{ الر اتب الثهري } \\
\hline$\% r \uparrow, \uparrow$ & $\varepsilon$. & 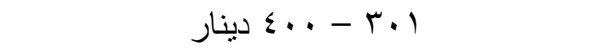 & \\
\hline$\%$. & vo & 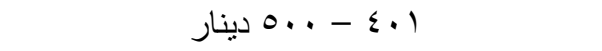 & \\
\hline$\% 1$. & 10 & 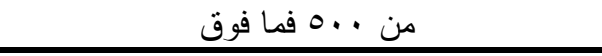 & \\
\hline$\% 1 .$. & 10. & 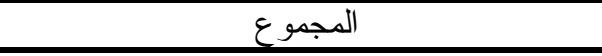 & \multirow{7}{*}{ طند تنفيذ المهام } \\
\hline $\begin{array}{ll}\% 1 \cdot, y \\
\% \circ q^{\prime}\end{array}$ & 17 & • • تصميم وتحليل البرامج ذات العلاقة بمهـام & \\
\hline$\% q, r$ & $1 \varepsilon$ & 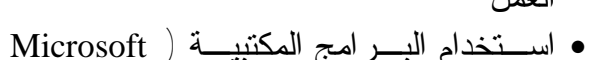 & \\
\hline$\% r \cdot, r$ & r & (office & \\
\hline & & • إذخال البيانات و استرجاعها & \\
\hline & & • استخدام شبكة الانترنيت والاتــصالات فــي & \\
\hline & & & \\
\hline$\% 1 .$. & 10. & الدجموع & \\
\hline
\end{tabular}

ثانياً - وصف متغير ات البحث وتثخيصها

نتتاول في هذا الجانب وصف متغير ات البحث وتشخيصها بهذف معالجتهـا

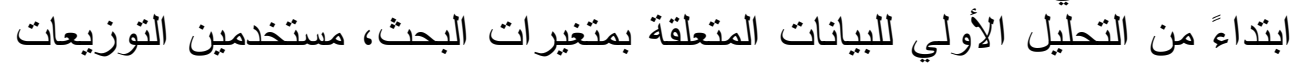

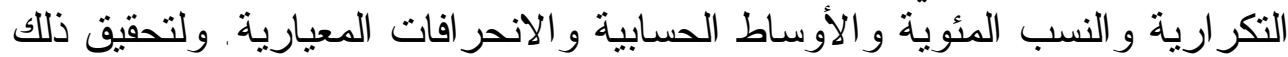

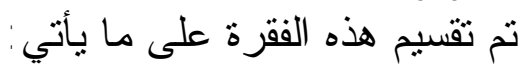

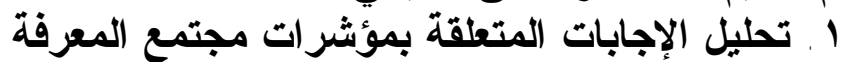

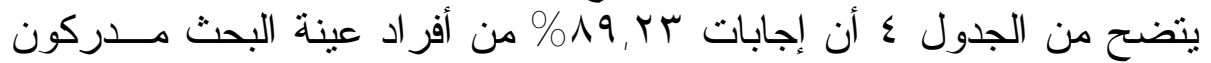

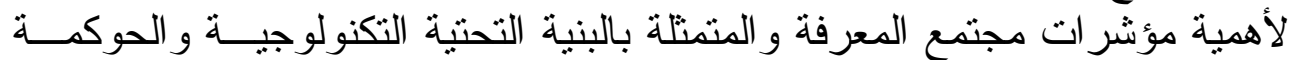

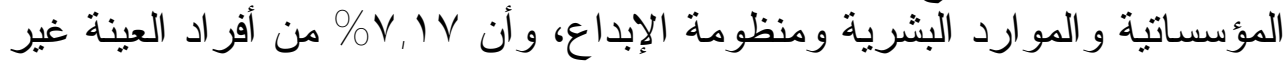

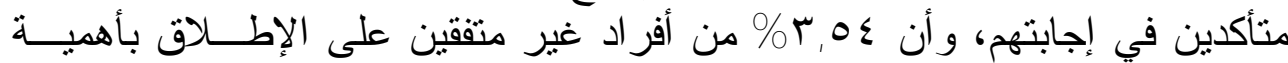

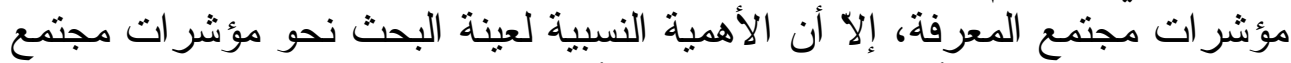

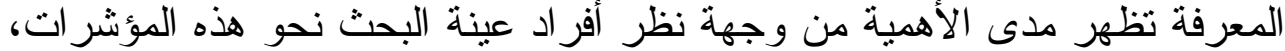


ويظهر ذلك من خلال مقدار الوسط الحسابي العام (1) (r, و الانحر اف المعيــاري

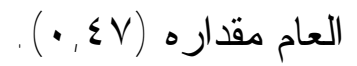

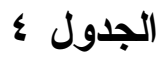

التوزيع التكراري والنسبي و الوسط الحسابي والاحتراف المعياري

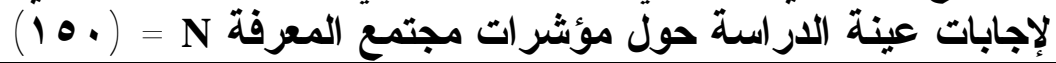

\begin{tabular}{|c|c|c|c|c|c|c|c|}
\hline \multirow{2}{*}{ الالاحرياف } & \multirow{2}{*}{ الحسابي } & \multicolumn{5}{|c|}{ مقياس الإجابة } & \multirow{2}{*}{ مؤشر المرفة مجتمع } \\
\hline & & تمامق & اتفق & نوعا & لا اتفق & 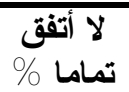 & \\
\hline$\cdot, \sum 9$ & $r, 9 \Lambda$ & $V 7,9 Y$ & $|r, r|$ & $V, 97$ & $r, \cdot 1$ & - & 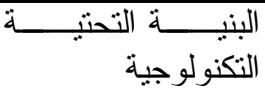 \\
\hline$\cdot, \leqslant 9$ & $r, 91$ & $\wedge \varepsilon, 7 q$ & $\varepsilon, \pi Y$ & $V, v$. & $r, \cdot \Lambda$ & - & الحوكمة المؤسساتية \\
\hline$\cdot, \xi \xi$ & $\overline{r, \Lambda \tau}$ & $\lambda r, 1$ & 7,10 & 7,10 & $\varepsilon, \pi)$ & - & الموارد البشرية \\
\hline$\cdot, \leqslant 7$ & $r, \lambda$. & $\lambda r, 1$ & $\begin{array}{l}, r Y \\
, Y\end{array}$ & $7,9$. & $r, 0$ & - & منظومة الإبداع \\
\hline$\cdot, \varepsilon V$ & $r, 91$ & $11,0 \leqslant$ & 8,79 & $\frac{V, I V}{V}$ & $r, 0 \xi$ & & المؤشر العام \\
\hline
\end{tabular}

r ـ تحليل الإجابات المتعلقة بعناصر العمل المعرفي

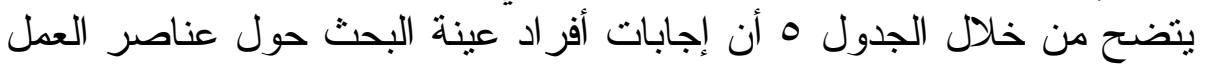

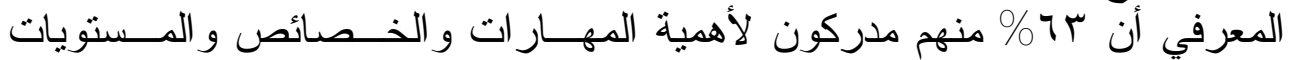

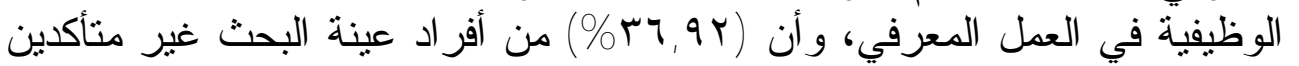
أو حياديين في إجاباتهم من ذلكئل الكئ.

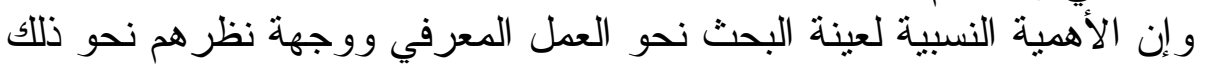

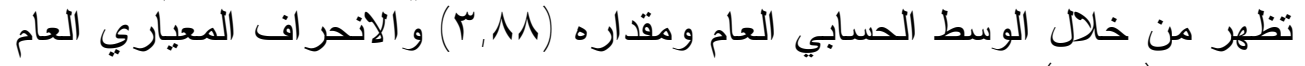

ومقداره (T) ـ • ).

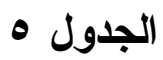

التوزيع النسبي والوسط الحسابي والاحمر اف المعياري

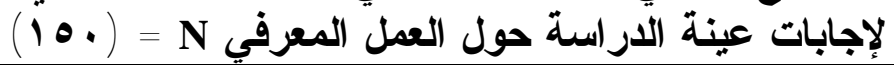

\begin{tabular}{|c|c|c|c|c|c|c|c|}
\hline \multirow{2}{*}{ المعياري } & \multirow{2}{*}{ الحسابي } & \multicolumn{5}{|c|}{ مقياس الإجابة } & \multirow{2}{*}{ عناصر العمل المعرفي } \\
\hline & & تمامـا & اتفق & نوعاً ما & لا أتقق & 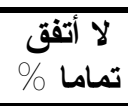 & \\
\hline$\cdot, \Gamma \mu$ & $\overline{r \lambda I}$ & $\overline{Y \Lambda, Y}$ & $|r, r|$ & $\lambda v, 79$ & - & - & الخصائص \\
\hline$\cdot \bar{r}, \mu$ & $r, \Lambda \Lambda$ & $r 0, r$ & $\lambda v, 79$ & $|r, r|$ & - & - & المستويات الوظيفية \\
\hline$\cdot, 7 \varepsilon$ & $r, 17$ & $r, r$ & $\varepsilon, 70$ & $1 \cdot, V V$ & - & - & المهارات \\
\hline$\cdot, \varepsilon r$ & $r, \Lambda \Lambda$ & $r \Lambda, r$. & $r \varepsilon, \Delta V$ & r४, QY & - & - & المؤشر العام \\
\hline
\end{tabular}


الدكتور العمري والدكتور السكارنة والحشاب [109]

ثالثاً - اختبار أنموذج البحث وفرضياته

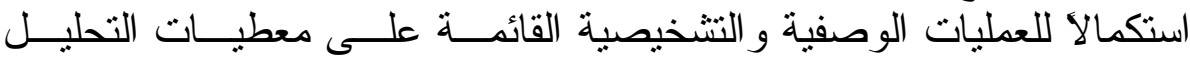

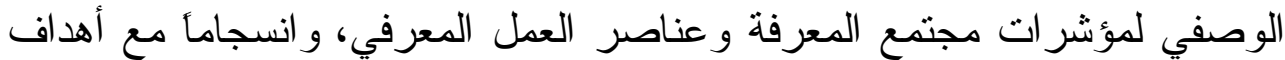

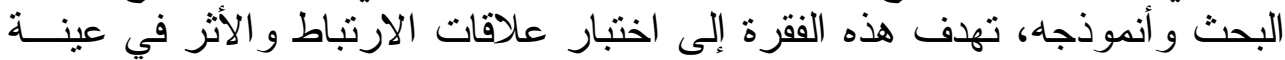
البحث ومن ثم التحقق من فرضياته فئه

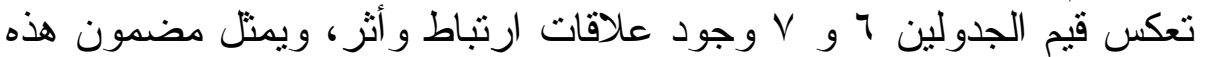

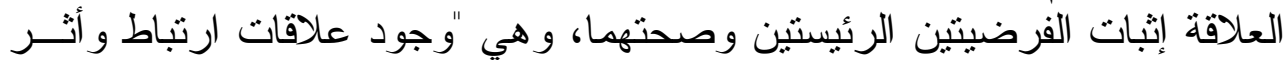

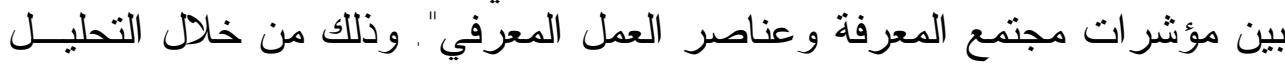

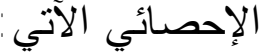
ا ـ تحليل علاقات الارتباط بين متغيرات البحث

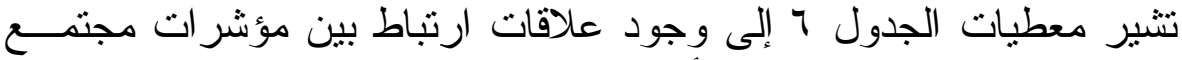

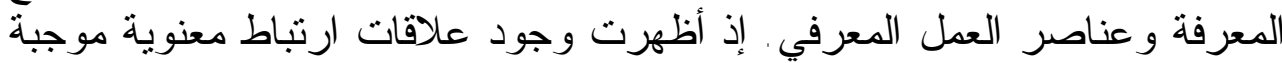

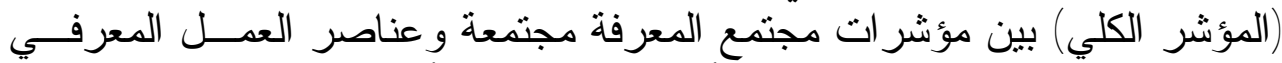

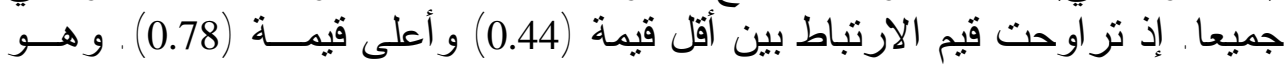

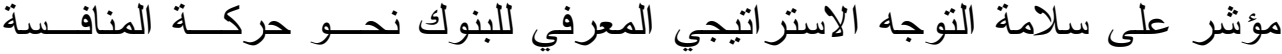

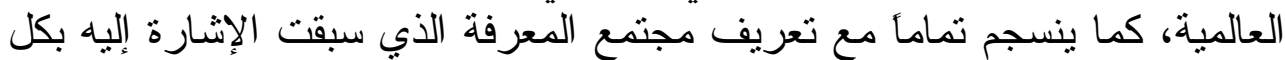

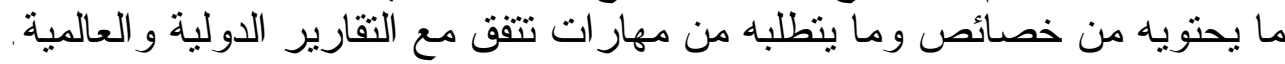

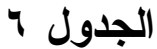

معامل الارتباط بين مؤشرات مجتمع المعرفة وعناصر العمل المعرفي

\begin{tabular}{|c|c|c|c|c|}
\hline المؤشر & مهار ات عمال & الوظيفي & العمل المعرفي & المتغير ات المستقلة المتغير ات المعتمدة \\
\hline$\cdot, \mathrm{\vee} \wedge$ & $*, 0 \mathrm{~V}$ & $*, \varepsilon \wedge$ & $*,, \vee 7$ & البنية التحتية التكنولوجية \\
\hline$\cdot, 77$ & $*, 7 V$ & $* ., 01$ & $*,, \leq \varepsilon$ & الموارد البشرية \\
\hline$\cdot, \leqslant \varepsilon$ & $*, r V$ & $*, V Y$ & $*, \vee \vee 7$ & منظومة الإبداع و التطوير \\
\hline.,$O Y$ & $*, \varepsilon r$ & $*, 70$ & $*, 7 \varepsilon$ & الحوكمة المؤسساتية \\
\hline
\end{tabular}

ويتبين من الجدول أيضـأ وجود علاقات ارتباط معنوية بــين مؤشــر البنيــة

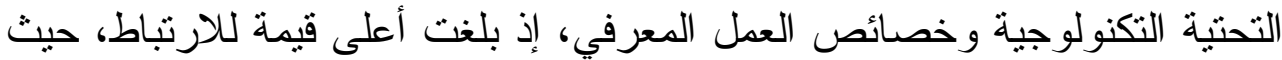
شكلت ( 0.76) من بين بقية المتغير ات .

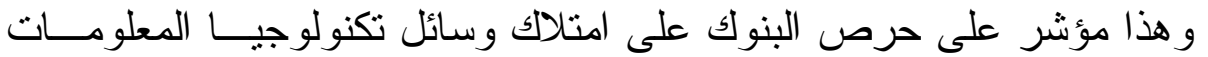

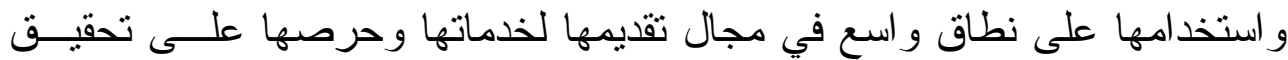
رضا وحاجات الزبائن المستجدة.

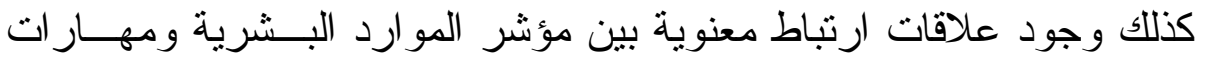

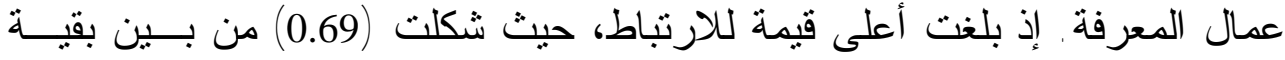

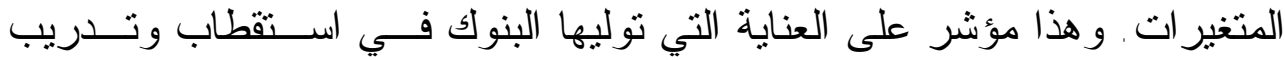


و المحافظة على مواردها البشرية وتعميق بناء الثقافة المعلوماتية و المعرفيــة فــي

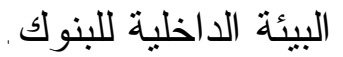

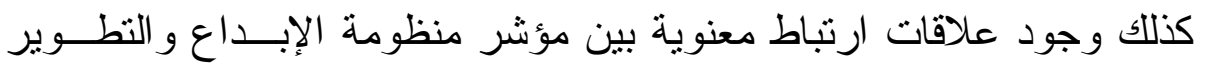

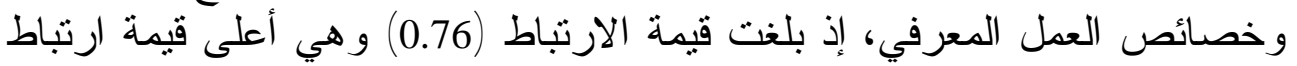

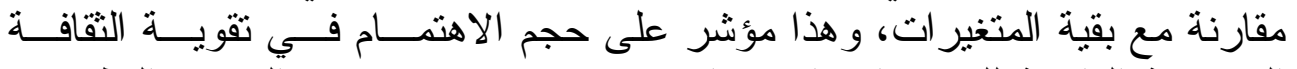

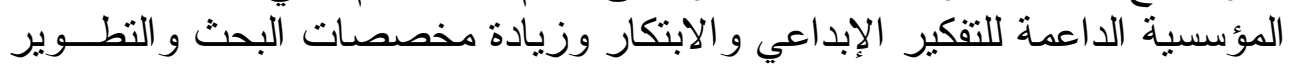

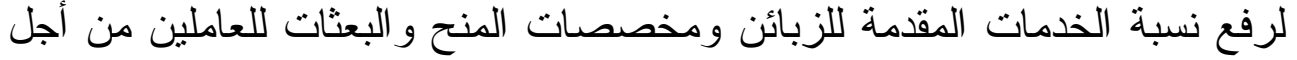

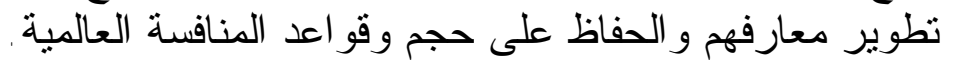

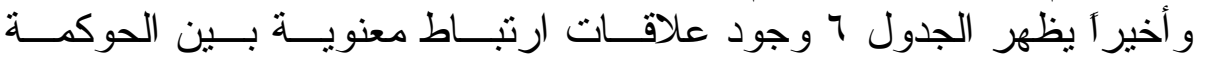

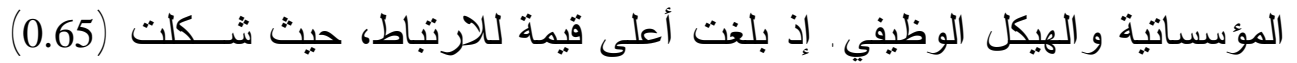

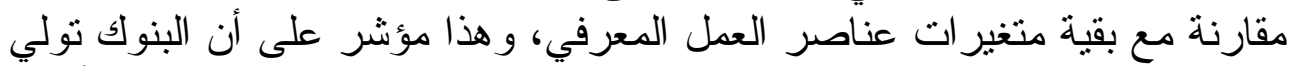

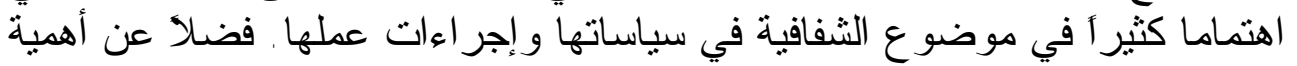

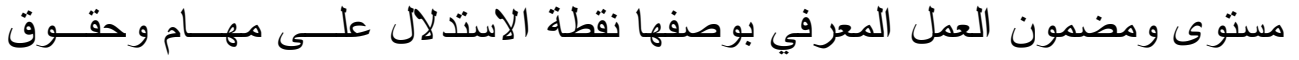
ومسؤوليات الموظف و علاقاته التتظيمية.

r. تحليل علاقات التأثير بين مؤشرات مجتمع المعرفة وعناصر العمل المعرفي

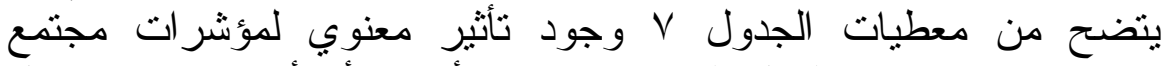

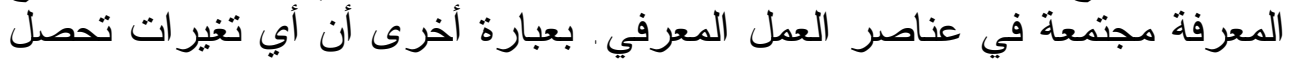

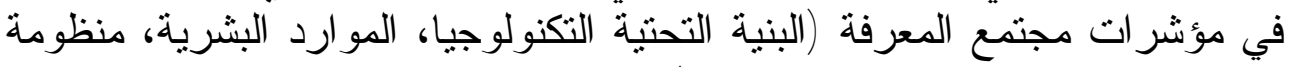

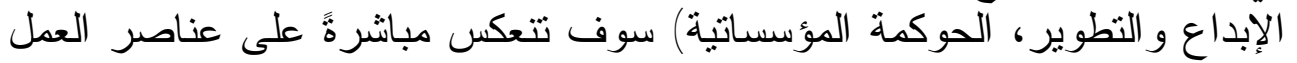
المعرفي من (خصائص و هيكلية ومهار ات) .

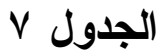

تأثير أبعاد مؤشرات مجتمع المعرفة في عناصر العمل المعرفي

\begin{tabular}{|c|c|c|c|c|c|c|c|}
\hline الجدولية & $\begin{array}{c}\text { المحسوبة } \\
\text { المسبة }\end{array}$ & $\overline{\mathbf{R}^{2}}$ & $\begin{array}{c}\text { المؤسساتية } \\
\text { B4 }\end{array}$ & والإبذاعة & $\begin{array}{l}\text { البشرية } \\
\text { B2 }\end{array}$ & $\begin{array}{c}\text { التكنولوجية } \\
\text { التوجية } \\
\text { B1 }\end{array}$ & قرتة \\
\hline$r, I V$ & $\lambda, \cdot 7$ & $\cdot, 7$ & $\begin{array}{l}(, r) \\
(1, \cdot v)\end{array}$ & $\begin{array}{l}\dot{P}, Y \\
(1,07)\end{array}$ & $\begin{array}{l}\cdot, r 0 \\
*(r, \wedge 1)\end{array}$ & $\begin{array}{l}\cdot, \cdot \wedge \\
(\cdot, r \Lambda)\end{array}$ & خصرائص العمل \\
\hline$r, I V$ & $r, v q$ & $\cdot, \varepsilon 1$ & $\begin{array}{c}\cdot, 00 \\
*(1,7 r)\end{array}$ & $\begin{array}{l}\dot{Y Y T} \\
(1,0 Y)\end{array}$ & $\begin{array}{l}\dot{Y r} \\
(\cdot, \wedge 0)\end{array}$ & $\begin{array}{c}\cdot,\{0 \\
*(r, \leqslant 1)\end{array}$ & الهيكل الوظيفي \\
\hline$r, I V$ & $7, \wedge \wedge$ &., 07 & $\begin{array}{l}\cdot, r \leq \\
(1, T r)\end{array}$ & $\begin{array}{c}\cdot, 74 \\
*(r, 94)\end{array}$ & $\begin{array}{c}\cdot, \varepsilon) \\
*(r, r \circ)\end{array}$ & $\begin{array}{l}\cdot, 1 T \\
(\cdot, 9 \cdot)\end{array}$ & مهار ات عمال \\
\hline
\end{tabular}


الدكتور العمري والدكتور السكارنة والحشاب [101]

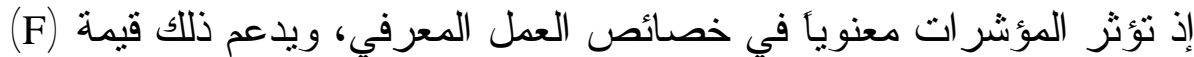

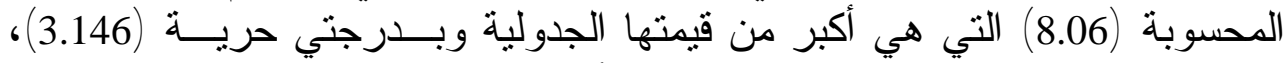

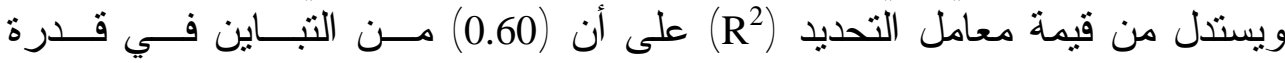

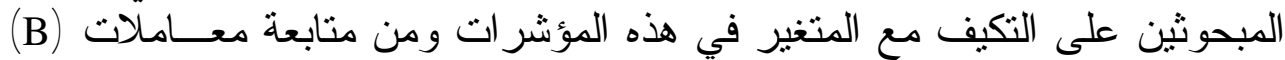

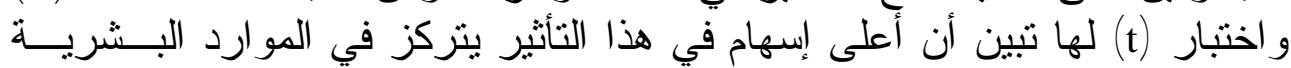

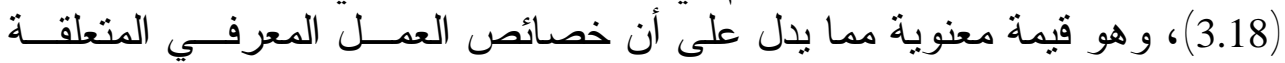

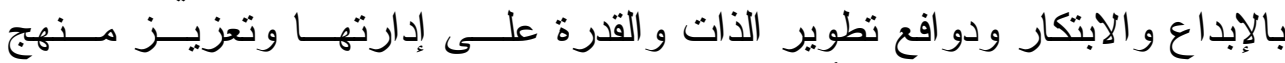

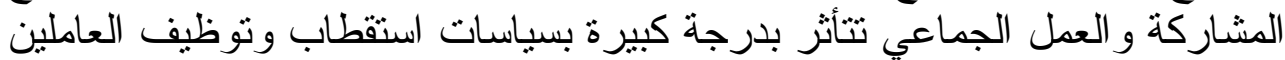

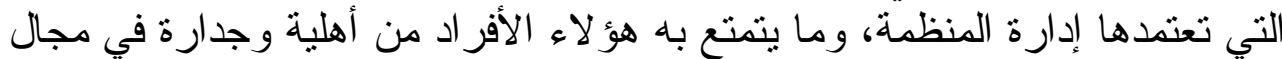

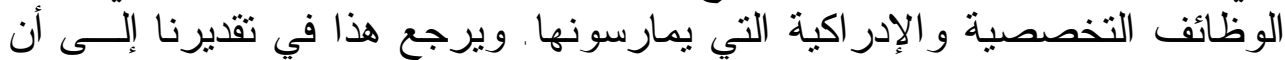

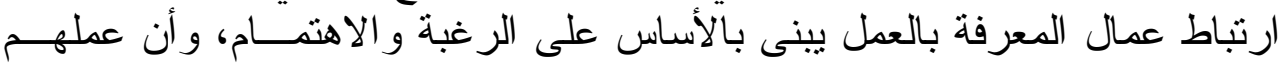

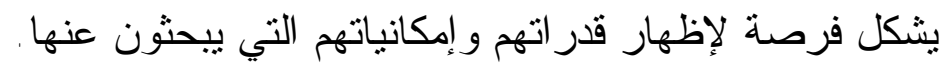

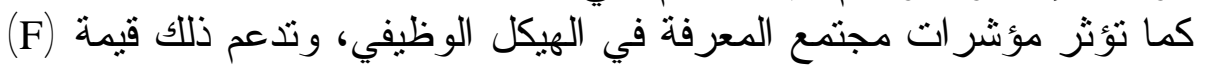

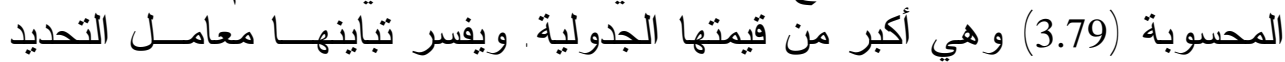
(R²) يتركز في مؤشر البنية التحتية التكنولوجية ومؤشر الحوكمـــة المؤسـسـاتية (2.41) (1.62) على التو الي، وهي قيم معنوية. وتتعكس هذه النتيجة العلاقة الجدلية القائمة

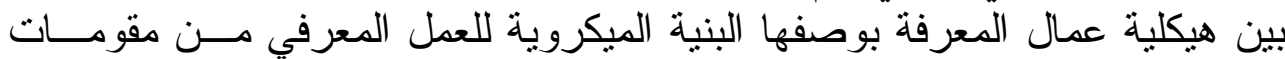
البنية التحتية التكنولوجية التتظيمية للمنظمة .

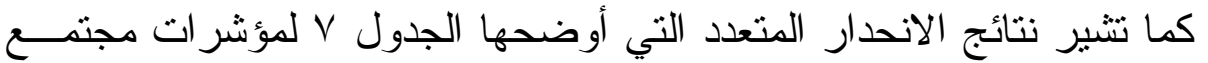

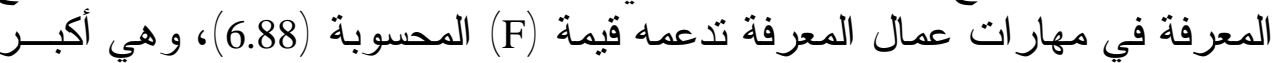

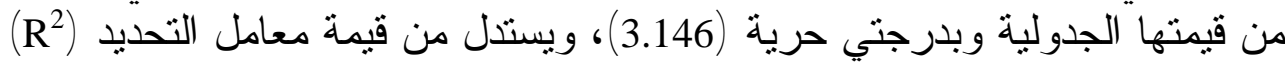

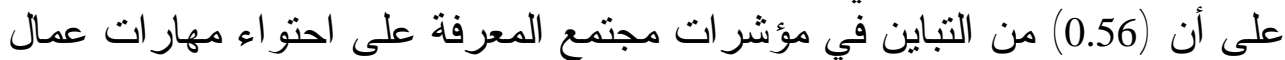

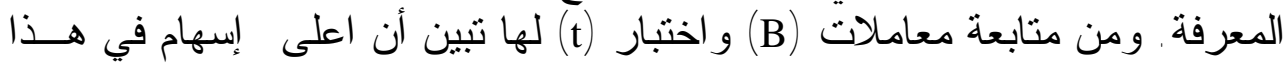

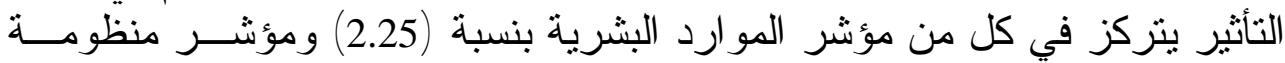

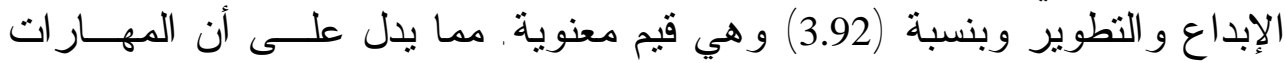

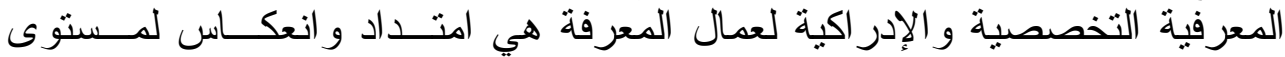

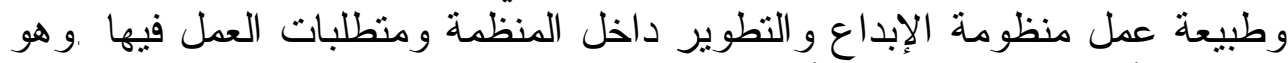

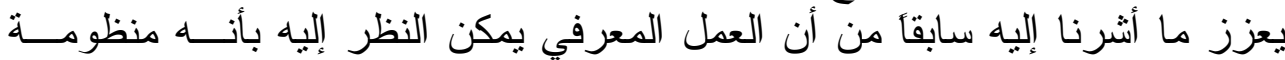

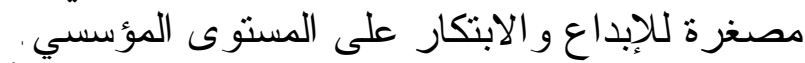

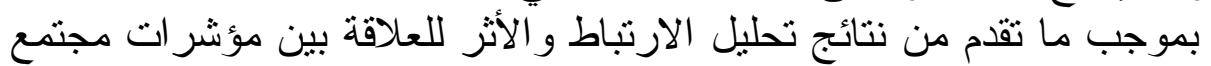

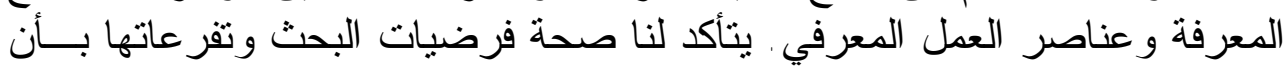

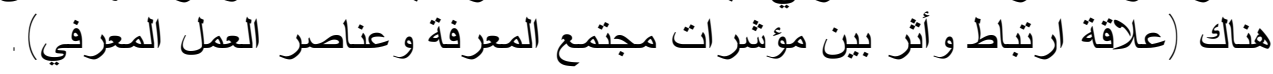




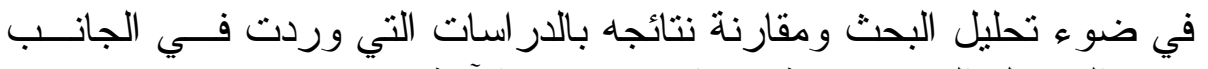

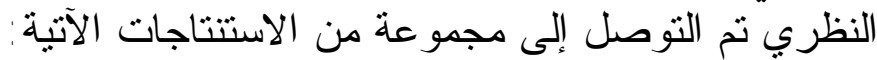

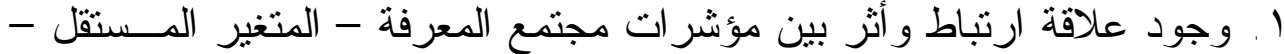

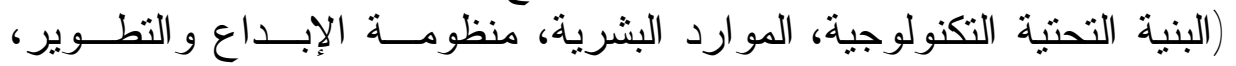

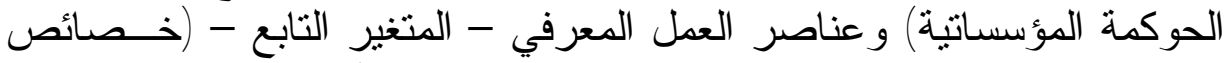

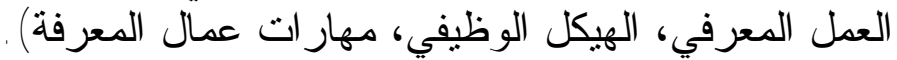

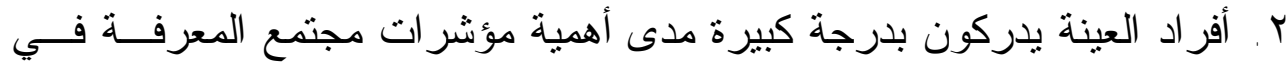

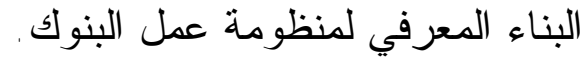

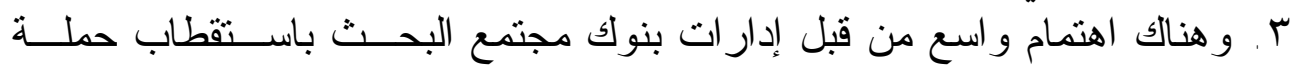

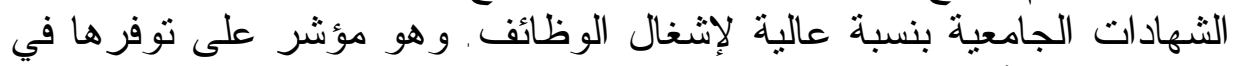

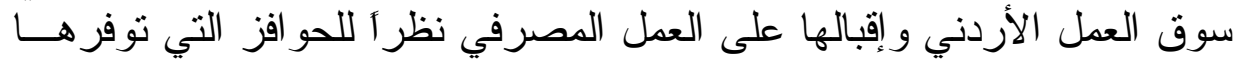
البنوك لموظفيها.

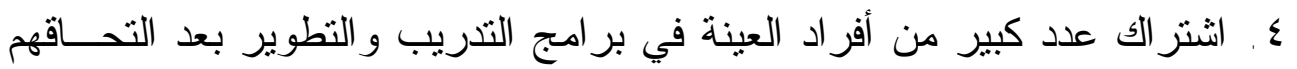

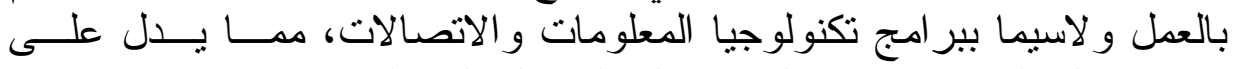

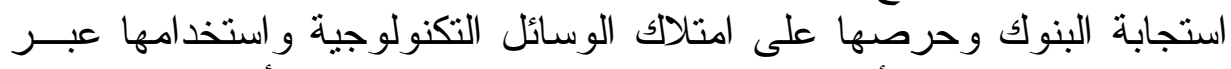

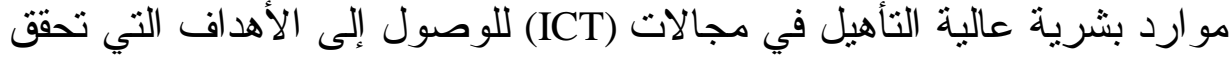

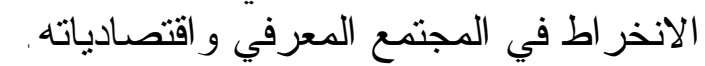

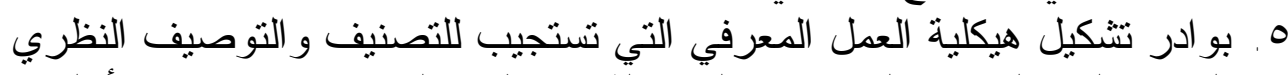

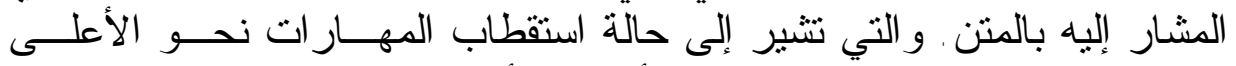

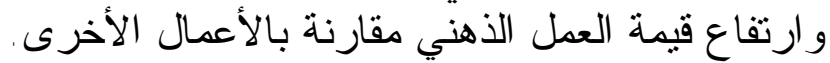

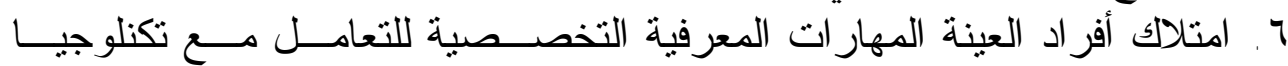

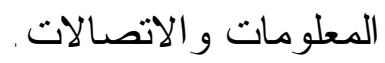

V. أفر اد العينة يدركون مدى أهمية المهار ات المعرفيــة الإدر اكيــــ (Soft skills) و وتأثير ها على عملهم.

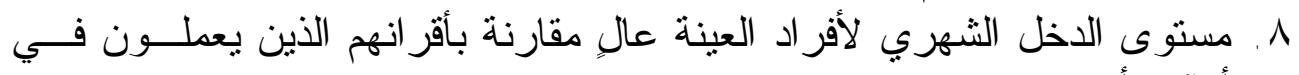

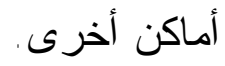

بناءً على استتناجات البحث المذكورة آنفأ، يوصي الباحثون البنوك الأردنية التوصيات

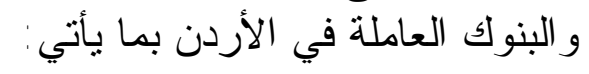

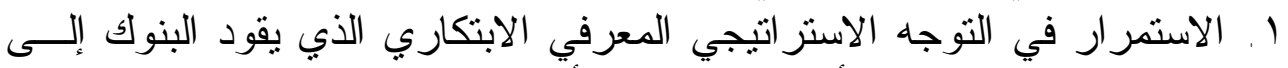

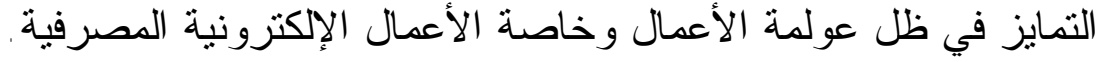


الدكتور العمري والدكتور السكارنة والحشاب [ [17]

r. الاستفادة من الثبكة العالمية (الإنترنت) في تقديمها لخدماتها وتعزيز اتجاهاتها التطورية المستقبلية.

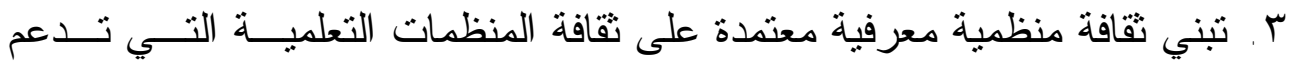

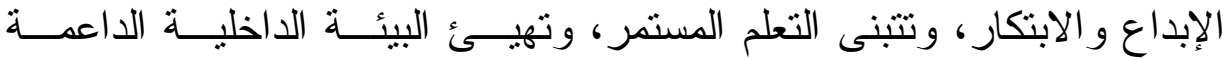

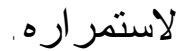

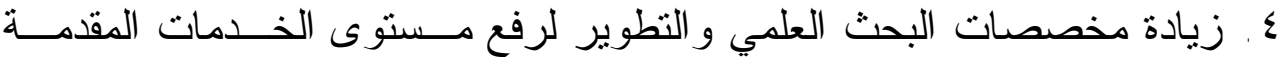

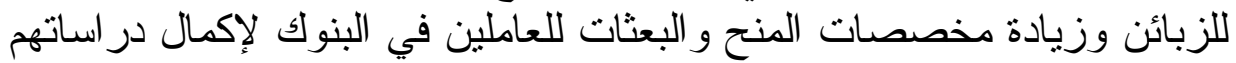
العليا.

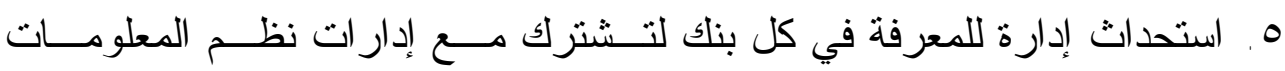

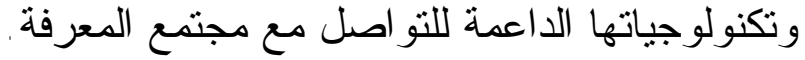

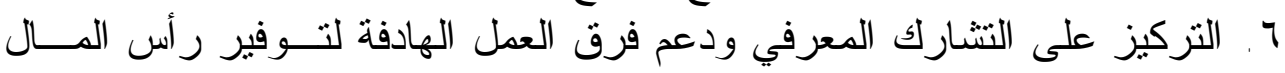

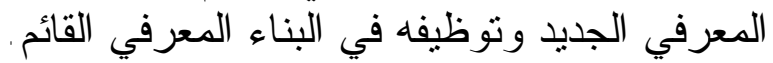

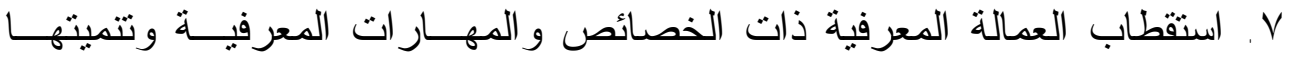

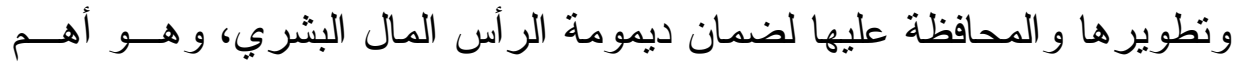

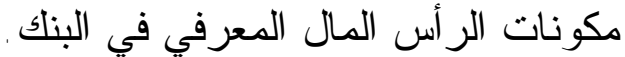

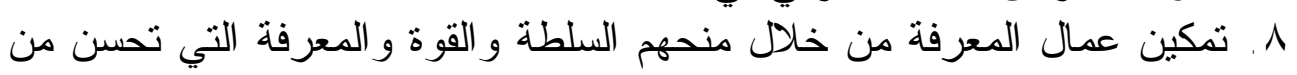

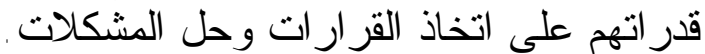

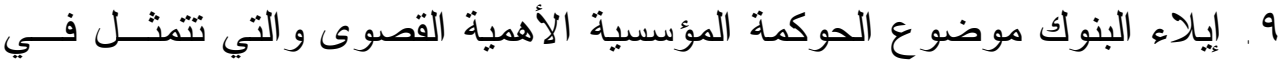

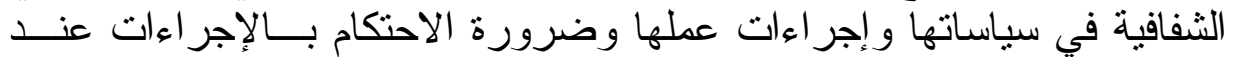

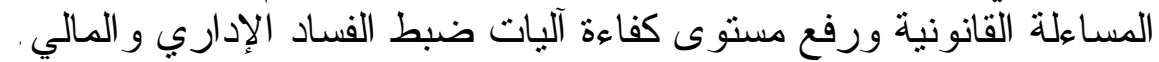

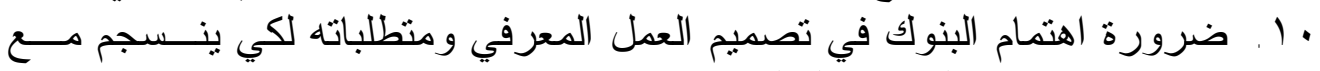
مؤشر ات مجتمع المعرفة العالمية.

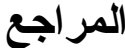 \\ أولاً - المرجع باع اللغة العربية}

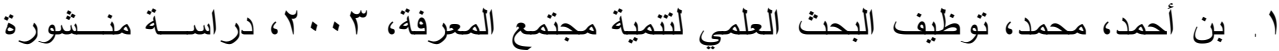

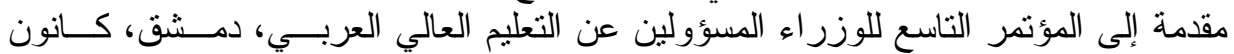

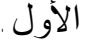

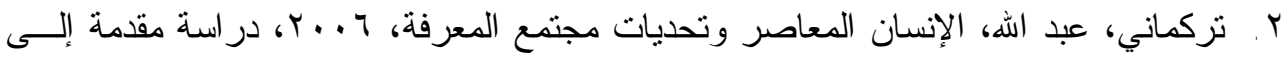

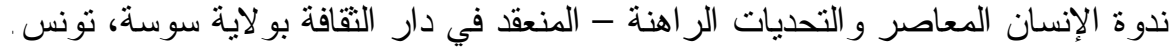

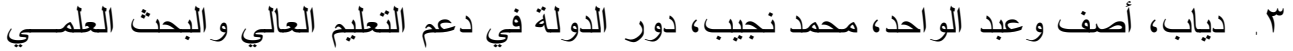

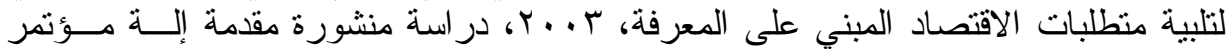

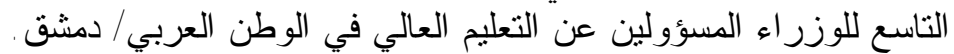

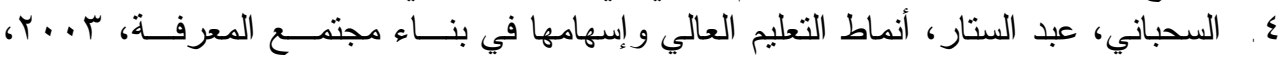
دراسة منشورة مقدمة إلى المؤتمر التاسع للوزر ألماء المسؤولين عن التعليم العالي في الــوطن

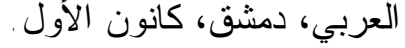




$$
\begin{aligned}
& {[|7|]} \\
& \text { مجتمع المعرفة وتأثيره في العمل المعرفي ... } \\
& \text { ه. السكارنه، بلال خلف، إستر اتيجية الريادة ودور ها في تحقيق الميزة التنافسية وتحسين الأداء }
\end{aligned}
$$

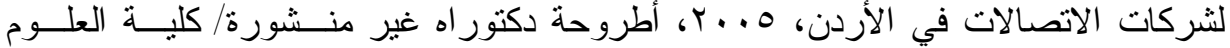

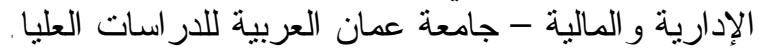

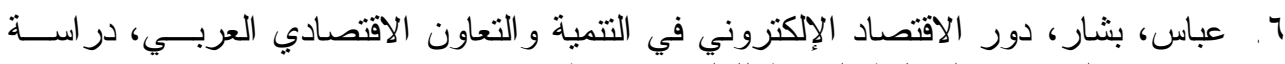

$$
\begin{aligned}
& \text { منشورة على موقع المنظمة العربية للعلوم الإدارية. }
\end{aligned}
$$

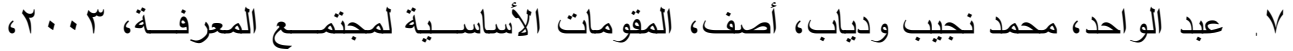

$$
\begin{aligned}
& \text { در اسة منشورة مقدمة إلى المؤتمر التاسع للوزر اء المسؤولئين عن التعليم العالي في الــوطن }
\end{aligned}
$$

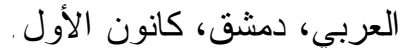

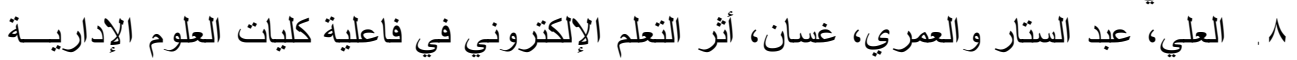

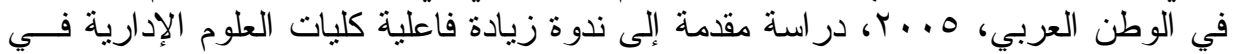

$$
\begin{aligned}
& \text { الوطن العربي المنعقدة في جامعة الزرقاء الوبة - الأردن. }
\end{aligned}
$$

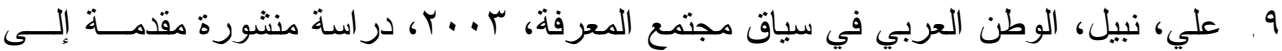

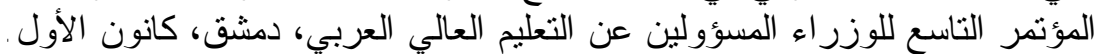

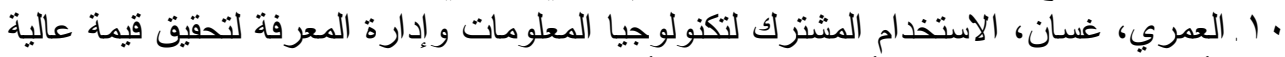

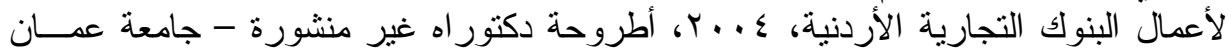

$$
\begin{aligned}
& \text { العربية للار اسات العليا. }
\end{aligned}
$$

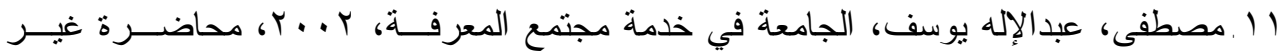

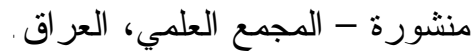

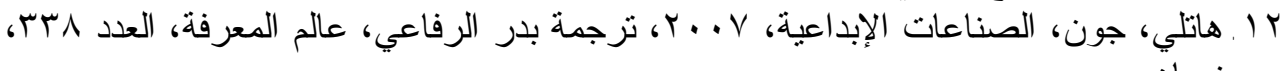

\section{ثانياً - المراجع باللغة الأجنبية}

1. Andrew Herrington "Maslow' S Hieyaychy, Societal Change and the Knowledge worker Revolution": 2005 (www.pateo.com).

2. Australian Bureau of Statistics (Knowledge Based Economy and society (KBE/S) Framework and Indicators) Asia - Pacific ICT Technical Meeting - Wellington, New Zealand: 2004.

3. BABSONKNOWLEDGE.ORG (Knowledge work, Management \& Productivity).

4. Blog.delaranja.com (A view on technology, social interactions, life and some wine).

5. Carl J. Dahlman and et. al. "Filand as Knowledge Economy Elements of success and lesson learned" International Bank For Reconstruction and Development/ word Bank: 2005.

6. Economist Print edition "Next society" Nov $1^{\text {st }} 2001$.

7. Economist Print edition "The New Work Force" Nov $1^{\text {st }} 2001$.

8. Hans - Dieter Eners "Towards a Malaysian Knowledge Society" Third International Malaysian Studies Conference (MSC3) Bangi: 2001.

9. Ian Brinkley and Neil Lee "Knowledge Economy in Europe" Work Foundation: 2006.

10. Paul A. David and Dominique Foray "Economic Fundamentals of the Knowledge society", All souls college, Oxford, OXI 4 Al, U.K.: 2002

11. Peter F. Druckter "Knowledge Work and Knowledge Society the social Transformations of this century: 1994" http://www.ksg.harvard.edu.

12. Toias Mueller - Prothmann "Knowledge Communities, Communities of Practice, and Knowledge Network Encyclopedia of Communities of Practice in Information and Knowledge Management: 2006 
الدكتور العمري والدكتور السكارنة والحشاب [بr 1]

\section{ثَالثاً - الانترنت}

1. Peter F. Druckter "Knowledge Work and Knowledge Society the social Transformations of this century: 1994" http://www.ksg.harvard.edu.

2. http://www.statcan.ca/Daily (The Daily study: Knowledge workers in Canada's work Force: 2003).

3. Thomas B Riley (An Overview of the Knowledge Economy (GOV: 2003) http://www.egovmonitor.com.

4. http://navcenter.borgess.com. (Knowledge worker Manual).

5. http://www.theworkfoundation.com (Knowledge Economy chart Focus).

6. http://www.theworkfoundation.com (The Knowledge Economy).

7. http://ec.europa.eu (Employment and social Affairs Knowledge Society).

8. http://Poratunesco.org (Towards Knowledge societies - First UNESCO world Report).

9. http://blogs.ittoolbox.com (Knowledge worker - taking Responsibility in Knowledge Based companies).

10. http://www.ansers.com (Knowledge worker: information from Answers.com).

11. http://navcenter.borgess.com (Knowledge worker Manual: what is a Knowledge worker?).

12. http://searchcrm.techtarget.com (what is Knowledge worker).

13. http://www.skyrme.com (Global Knowledge Economy).

14. http://www.Familtysearch.org (Man - Powering the Knowledge Economy).

15. http://www.developmenteay.org (Knowledge Economy).

16. http://www.jpa.gov (Knowledge workers). 